Florida International University FIU Digital Commons

$11-4-2008$

\title{
Numerical groundwater flow modeling in the Wakal River basin, India
}

Himadri Biswas

Florida International University

DOI: $10.25148 /$ etd.FI14051158

Follow this and additional works at: https://digitalcommons.fiu.edu/etd

Part of the Water Resource Management Commons

\section{Recommended Citation}

Biswas, Himadri, "Numerical groundwater flow modeling in the Wakal River basin, India" (2008). FIU Electronic Theses and Dissertations. 1683.

https://digitalcommons.fiu.edu/etd/1683

This work is brought to you for free and open access by the University Graduate School at FIU Digital Commons. It has been accepted for inclusion in FIU Electronic Theses and Dissertations by an authorized administrator of FIU Digital Commons. For more information, please contact dcc@fiu.edu. 
FLORIDA INTERNATIONAL UNIVERSITY

Miami, Florida

NUMERICAL GROUNDWATER FLOW MODELING IN THE WAKAL RIVER

BASIN, INDIA

\author{
A thesis submitted in partial fulfillment of the \\ requirements for the degree of \\ MASTER OF SCIENCE \\ in \\ ENVIRONMENTAL STUDIES \\ by
}

Himadri Biswas 
To: Dean Kenneth Furton

College of Arts and Sciences

This thesis, written by Himadri Biswas, and entitled Numerical Groundwater Flow Modeling in the Wakal River Basin, India, having been approved in respect to style and intellectual content, is referred to you for judgment.

We have read this thesis and recommend that it be approved.

Michael E. McClain

Michael Sukop

Mahadev Bhat

Assefa M. Melesse, Major Professor

Date of Defense: November 4, 2008

The thesis of Himadri Biswas is approved.

Dean Kenneth Furton College of Arts and Sciences

Dean George Walker University Graduate School

Florida International University, 2008 


\section{DEDICATION}

I dedicate this thesis to my parents, Bob, Pooja, and Mayur. I also dedicate this work to the people living in the Wakal River Basin. 


\section{ACKNOWLEDGMENTS}

I would like to express my sincere gratitude to the members of my committeeDr. Assefa Melesse, Dr. Michael McClain, Dr. Mahadev Bhat, and Dr. Michael Sukopfor their encouragement, advising and valuable suggestions that helped me to accomplish my goals of finishing this research. I am greatly indebted to my major professor Dr. Assefa Melesse for his guidance and encouragement throughout my study period. Special thanks to Dr. Michael McClain for guiding me with valuable advice and comments to improve my research work. I am also indebted to Dr. Michael Sukop, for laying me a sound foundation on groundwater modeling during my study.

I would like to thank my colleagues at Florida International University - Daniel Gann, John Stiefel, Dr. Elizabeth Anderson, Yirgalem Assegid, Nenpan Tunkuda - for their continuous support and valuable suggestions. Particular thanks to Mr. Daniel Gann for his time, resources, suggestions and support. Special thanks to John for his valuable suggestions, support, encouragement and friendship.

I would like to thank my colleagues in India for their precious contribution for this research. Special thanks to World Vision India for facilitating the research in Rajasthan. Particular thanks to Pratyush, Adison, Laxman, Maragaret and other staff of ADP Navprabhat. I would also like to thank Dr. N.K. Chauhan, Mr. A.K Bordia, and Dr. P.K. Singh for providing deep insight and knowledge as well as their significant contribution in making data and resources available to me. I am especially thankful to the villagers in the study area for their help, without which it would not have been possible to conduct this research. 
Special thanks to the Department of Environmental studies for providing me the opportunity to study for Master of Science degree in the United States. I would like to acknowledge Global Water for Sustainability (GLOWS) Program for funding the research through United States Agency for International Development (USAID).

Finally, my deep gratitude and appreciation goes to my parents, Bob, Pooja and Mayur for their immense support, patience and love. 
ABSTRACT OF THE THESIS

NUMERICAL GROUNDWATER FLOW MODELING IN THE WAKAL RIVER

BASIN, INDIA

by

Himadri Biswas

Florida International University, 2008

Miami, Florida

Professor Assefa M. Melesse, Major Professor

Increasing dependence on groundwater in the Wakal River basin, India, jeopardizes water supply sustainability. A numerical groundwater model was developed to better understand the aquifer system and to evaluate its potential in terms of quantity and replenishment. Potential artificial recharge areas were delineated using landscape and hydrogeologic parameters, Geographic Information System (GIS), and remote sensing.

Groundwater models are powerful tools for recharge estimation when transmissivity is known. Proper recharge must be applied to reproduce field-measured heads. The model showed that groundwater levels could decline significantly if there are two drought years in every four years that result in reduced recharge, and groundwater withdrawal is increased by $15 \%$. The effect of such drought is currently uncertain however, because runoff from the basin is unknown. Remote sensing and GIS revealed areas with slopes less than 5\%, forest cover, and Normalized Difference Vegetative Index greater than 0.5 that are suitable recharge sites. 


\section{TABLE OF CONTENTS}

CHAPTER

PAGE

1.0 INTRODUCTION

1.1. Background

1.2. Statement of the problem 1

1.3. Goals and objectives 3

1.4. Significance of study 4

1.5. Research questions and hypotheses 4

2.0. LITERATURE REVIEW 6

2.1. Groundwater modeling 6

2.2. Groundwater modeling studies 9

2.3. Groundwater flow studies in fractured hard rock aquifers 14

2.4. Delineation of recharge areas using remote sensing and GIS 15

$\begin{array}{lll}3.0 & \text { DESCRIPTION OF STUDY AREA } & 18\end{array}$

3.1. Location of study area 18

3.2. Climate 19

3.2.1. Rainfall 20

3.2.2. Temperature $\quad 22$

3.2.3. Relative humidity 22

3.2.4. Evapotranspiration 23

3.3. Hydrology 24

3.3.1. Surface water bodies $\quad 24$

3.3.2. Water balance of the catchment 25

3.4. Geomorphology 26

3.5. Geology 27

3.6. Hydrogeology 29

3.7. Water use 31

4.0 METHODOLOGY 32

4.1. Field data collection program $\quad 32$

4.1.1. Wells 33

4.1.2. Groundwater level 34

4.1.3. Groundwater extraction 35

4.2. Evaluation of aquifer properties 36

$\begin{array}{ll}\text { 4.3. Recharge } & 37\end{array}$

4.4. Groundwater modeling 38 
4.5. Conceptual model 40

4.5.1. Hydrostratigraphic units 40

4.5.2. Surface water bodies $\quad 41$

4.5.3. Recharge zones 41

4.5.4. Groundwater exploitation $\quad 42$

4.5.5. Boundaries $\quad 42$

4.6. Type of model 44

4.7. Code selection $\quad 44$

4.7.1. Model code 44

4.7.2. Rationale for selecting MODFLOW 46

4.8. Processor 46

4.9. Model Set-up 47

4.9.1.Model Domain 47

4.9.1.1. Horizontal extent $\quad 47$

4.9.1.2. Vertical extent $\quad 47$

4.9.1.3. Discretization $\quad 48$

4.9.2. Model Boundaries 48

4.9.2.1. Lateral model boundaries $\quad 49$

4.9.3. Model layer thickness $\quad 49$

4.9.4. Initial hydraulic head $\quad 50$

4.9.5. Hydraulic parameters $\quad 50$

4.9.6. Recharge $\quad 52$

4.9.7. Boreholes and observation wells $\quad 52$

4.9.8. Groundwater exploitation $\quad 52$

4.9.9. Evapotranspiration 53

4.10. Methodology for the delineation of artificial recharge sites 53

4.10.1. Drainage and catchments 54

4.10.2. Slope $\quad 55$

4.10.3. Geology 57

4.10.4. Geomorphology 57

4.10.5. Land cover/Land use $\quad 58$

4.10.6. Normalized Difference Vegetation Index (NDVI) 60

4.10.7. Groundwater level data 61

5.0. Results and Discussions 65

5.1. Evapotranspiration $\quad 65$

$\begin{array}{ll}\text { 5.2. Groundwater extraction } & 67\end{array}$

5.3. Aquifer properties $\quad 68$

5.4. Model calibration $\quad 69$ 
5.4.1. Trial-and-error calibration $\quad 70$

5.1.2. Evaluation of trial-and-error calibration $\quad 70$

$\begin{array}{ll}\text { 5.5. Steady-state model calibration } & 72\end{array}$

5.5.1. Steady-state model verification 73

$\begin{array}{ll}\text { 5.5.2. Steady state model results } & 73\end{array}$

5.5.2.1. Hydraulic head 73

$\begin{array}{ll}5.5 .2 .2 \text {. Transmissivity } & 80\end{array}$

5.5.2.3. Recharge $\quad 81$

5.5.2.4. Groundwater budget $\quad 82$

5.6. Transient-state model calibration $\quad 82$

5.6.1. Transient-state model results $\quad 84$

$\begin{array}{lr}\text { 5.7. Model prediction } & 90\end{array}$

5.7.1. Model scenario 1: $15 \%$ increase in withdrawal 90

5.7.2. Model scenario 2: Two consecutive drought years in every four years 92

5.7.3. Model scenario 3: Combined effect of drought years and withdrawal increase 94

5.8. Results for delineation of recharge sites 95

5.8.1. Suitable recharge sites $\quad 97$

5.9. Discussions 98

6.0. CONCLUSIONS AND RECOMMENDATIONS 101

$\begin{array}{ll}\text { REFERENCES } & 104\end{array}$

$\begin{array}{ll}\text { APPENDICES } & 110\end{array}$ 


\section{LIST OF TABLES}

TABLE

PAGE

Table 3-1. Stratigraphic succession of the Aravalli Mountains

(After Roy, 1988). Source: Mohemmad, 1993.

Table 3-2. Stratigraphic succession of the rocks in the study area catchment.

Source: Chauhan et. al., 1996.

Table 4-1. Statistics of well diameter and total well depth.

Table 4-2. Natural recharge estimates in hard rock aquifers by different methods. 39

Table 4-3. Storage coefficient estimates for different rock types in Aravalli

Mountains. Source: Government of Rajasthan, 1979

Table 5-1. Statistics of Pan Evaporation and Reference Crop ET

(Modified Penman-Monteith) for 2006

Table 5-2. Groundwater consumption in the study area.

68

Table 5-3. Transmissivity for different rock types (Source: GOR, 1979)

69

Table 5-4. Statistical evaluation of simulated and observed heads.

Table 5-5. Statistical parameters of the calibrated model.

Table 5-6. Variation of transmissivity in different zones.

Table 5-7. Variation of recharge in different zones.

Table 5-8. Groundwater budget of the calibrated model

Table 5-9. Ranking of parameters. 


\section{LIST OF FIGURES}

FIGURE

PAGE

Figure 3-1. Location of study area.

Figure 3-2. Annual rainfall distribution in the Wakal Basin (1965-2005).

Figure 3-3. Mean monthly rainfall distribution in the Wakal Basin (1965-2005).

Figure 3-4. Daily maximum and minimum relative humidity in the Wakal Basin for 2006.

Figure 3-5. Elevation map of Wakal basin.

Figure 3-6. Elevation map of study area.

Figure 3-7. Lithology of study area catchment.

Figure 3-8(a). Photograph showing joints in Quartzitic rocks.

Figure 3-8(b). Photograph showing groundwater seeping through joints and fractures.

Figure 4-1. Open dug wells.

Figure 4-2. Model domain showing horizontal extent and boundaries.

Figure 4-3. Flow chart showing the methodology for the delineation of recharge sites.

Figure 4-4. Map showing catchment and drainage lines.

Figure 4-5. Slope map of the study area.

Figure 4-6. Map of land cover / land use.

Figure 4-7. Map of NDVI in the study area.

Figure 4-8(a). Map showing the location of open dug wells.

Figure 4-8(b). Map showing changes in groundwater level. 
Figure 4-11. Map showing areas with slope less than 5\%, forest cover and NDVI greater than 0.5 .

Figure 4-12. Map showing areas with slope less than 5\%, forest cover, high NDVI and groundwater level.

Figure 5-1. Daily variations of Pan Evaporation and Reference Crop ET (ETo in 2006.

Figure 5-2. Temporal variation of rainfall and evapotranspiration in 2006.

Figure 5-3. Groundwater consumption by various sectors in the study area. $\quad 67$

Figure 5-4. Scatterplot of simulated and observed heads.

Figure 5-5. Comparison of spatial distribution of simulated heads and observed heads.

Figure 5-6. Spatial distribution of residuals.

Figure 5-7. Spatial distribution of regional simulated heads with observed heads. 78

Figure 5-8. Scatter plot of simulated and observed heads of the verified model.

Figure 5-9. Transmissivity zones.

Figure 5-10. Recharge zones.

Figure 5-11. Head response of 19 monitoring wells during a period of 5 years. 83

Figure 5-12. Plot of simulated against observed heads for the year 2005-2006. 87

Figure 5-13. Map showing the pre- and during-monsoon groundwater level of 2006 and groundwater velocity vectors.

Figure 5-14. Variation of coefficient storage in different zones.

Figure 5-15. Contour plot of simulated heads after monsoon of 2006 and 2010. 91

Figure 5-16. Simulated heads of wells until December 2010 under increased pumping conditions by $15 \%$

Figure 5-17. Simulated heads of wells until 2010 under drought scenario. 
Figure 5-18. Comparison of simulated heads after monsoon of 2006 and 2010 under drought scenario.

Figure 5-19. Comparison of simulated heads after monsoon of 2006 and 2010 under combined drought and increased withdrawal scenario

Figure 5-20. Simulated heads of well through 2010 under model scenario 3.

Figure 5-21. Maps showing the location of suitable recharge sites with forest land cover.

Figure 5-22. Map showing the location of suitable recharge sites with agricultural land as land cover. 


\subsection{INTRODUCTION}

\subsection{Background}

Because of limited surface water availability and deteriorating water quality in some countries, groundwater has become the principal source of freshwater for all uses. Presently, about one-third of the world's population lives in countries that are facing water stress conditions and this fraction is expected to rise to two-third by 2025 (GWP, 2000). This includes India, which has $16 \%$ of the global population but only $3 \%$ of the global freshwater reserves (ECIDWR, 2005). The high dependence on groundwater and ever-increasing demand with increasing population for domestic, irrigation and industrial needs has put immense pressure on this natural resource, particularly in semi-arid and arid regions (Sukhija et al., 1996; de Vries and Simmers, 2002).

\subsection{Statement of the problem}

Rajasthan is the largest and driest state in India (Narain et al., 2005; Rathore, 2005a). This state constitutes $10.4 \%$ of India's total geographical area and $5.4 \%$ of the nation's population but has only $2.86 \%$ (1.16\% surface water and $1.7 \%$ ground water) of the total water resources of the nation (ECIDWR, 2005). Rajasthan experiences a varied climatic condition ranging from extreme aridity to sub-humid and humid conditions. However, most of the state (about $94 \%$ ) falls under arid and semi-arid conditions with erratic rainfall patterns (Rathore, 2005b.). Nearly $90 \%$ of the total rainfall in Rajasthan is received during the southwest monsoon from late June to mid September (ICID, 2005). Low availability of surface water as well as groundwater can be explained by intermittent rainfall distribution patterns and terrain characteristics, as well as high runoff and 
evaporation which lead to reduced storage of water (Rathore, 2005b). Approximately $80 \%$ of Rajasthan's annual precipitation is lost due to evaporation, $7 \%$ contributes to recharge of groundwater, and about $13 \%$ ends up as surface flow (ECIDWR, 2005). Presently, there is tremendous pressure to exploit groundwater for drinking, domestic and agricultural use. Due to insufficient surface water resources, the entire state is primarily dependent on groundwater for its requirements (Rathore, 2005b). Groundwater is used extensively to meet $80 \%$ of drinking water needs and approximately $67 \%$ of irrigation needs (UNDP, 2005). Recurring and prolonged drought is a common phenomenon which intensifies water shortages (Narain et al., 2005). Water scarcity is becoming a serious issue during droughts as most of the tanks and reservoirs receive low runoff from their catchments and are only partially filled and, therefore, dry out more quickly than normal (Narain et al., 2005).

People in Rajasthan withdraw groundwater for domestic and irrigation purposes through traditional open dug wells and bore wells through traditional manual water lifting devices as well as diesel and electric pumps. Due to increasing population and the need for more water for better living conditions, the withdrawal of groundwater has also increased (Mahnot et al., 2003). Due to increasing demand for groundwater, there has been unparalleled growth in the number of open dug wells, bore wells, diesel pumps and electric pump sets (UNDP, 2005). These factors have led to the over-extraction of groundwater in some regions. Another problem associated with over-dependence on groundwater is declining water quality, which is reflected in high salinity, fluoride and nitrate concentrations in some regions of Rajasthan (ECIDWR, 2005; UNDP, 2005). 
To overcome the groundwater scarcity problem, people in Rajasthan have traditionally been using various artificial recharge techniques such as nadi, tanka, jhalara $k u n d$, etc. to store water. Recently, these techniques are gaining popularity owing to increasing population, recurring droughts and decreasing groundwater levels (Narain et al., 2005). But Rathore (2005b) has reported that these structures are built without having sound technical information on the overall context of groundwater and often key hydrological parameters are not estimated and also little or no effort is made to model hydrologic dynamics.

In response to this ever increasing scarcity problem, a numerical groundwater model was developed for a small catchment in the water scarce Wakal River Basin in southern Rajasthan to better understand the climatic, geologic and hydrologic factors affecting the aquifers in the area and predict the sustainability of the aquifers by applying different stress conditions. In addition, a conjunctive Geographic Information System (GIS) and remote-sensing based approach was taken to identify the factors affecting recharge and to delineate potential recharge sites.

\subsection{Goals and objectives}

The primary goal of this research is to simulate the level of groundwater in the basin for the different parts of the year as a function of monsoon recharge and abstraction using a numerical modeling technique. The approach is to systematically collect hydrogeological, meteorological and geospatial information of the study area in the Wakal Basin and develop a conceptual model for implementing the simulation in 
PMWIN (ver. 5.3.0), Processing Modflow for Windows (Chiang and Kinzelbach, 2003).

The specific objectives of the study are to:

1. Characterize the types of aquifers present within the study area and estimate their hydraulic properties

2. Establish the effects of geology, lithology, land-use etc on groundwater using GIS

3. Model and simulate the potential changes in groundwater levels from different groundwater recharge and extraction rates using PMWIN

4. Evaluate the performance of the model in replicating the observed groundwater readings

5. Delineate potential groundwater recharge sites using GIS and remote sensing

\subsection{Significance of the study}

To be able to exploit this natural resource in a sustainable manner with minimal impact on the environment, there is a need to understand the hydrogeology of the area, delineate the aquifers in the area and model their potential in terms of water quantity and replenishment. A detailed understanding of the replenishment or the recharge of these aquifers will assist planners in determining the optimal exploitation of the resource.

\subsection{Research Questions and Hypotheses}

The study objectives will be achieved by investigating the following research questions: 
1. What is the present status of water use in the study area? Who are the main users of groundwater? Is there any detrimental over-extraction? What impact does it have on the ground water level?

2. How long can the aquifers sustain the needs of the people at current extraction rates?

3. What are the effects of climatic factors, geology and hydraulic properties on groundwater?

The following hypotheses are posed to focus the research:

1. Over-use of groundwater resources has increased the water crisis in the Wakal Basin.

2. The present extraction rate is not sustainable and the over-exploitation will increase with growing demand leading to acute water shortages. 


\subsection{LITERATURE REVIEW}

This chapter provides review of the previous studies on groundwater modeling carried out in India and other places which were applicable to the study of the groundwater flow system in the study area and other similar settings. It is hard to mention all the groundwater modeling studies, rather only a few selected studies have been mentioned which provided specific information used during this study. The review also summarized groundwater modeling studies on fractured geologic units, which is a setting similar to the study area.

\subsection{Groundwater modeling}

Groundwater models are being used extensively worldwide for various purposes which include understanding the nature of flow of groundwater and predicting the behavior of aquifers under different stress conditions. Groundwater models are simplistic representation of the real world hydrogeological system. Depending upon the objective of groundwater modeling, a groundwater model can be generic, interpretive or predictive. A generic model is used to investigate a hypothetical hydrogeological system; an interpretive model is used to explore system dynamics or categorize data; whereas a predictive model, which is the most common of all, is used to foresee future conditions (Anderson and Woessner, 2002).

Several types of models have been used by various scientists to understand groundwater flow systems, some of which include sand tank models, analog models, and mathematical models. However, mathematical models are widely used compared to any other model because of their convenience. In a mathematical model, the groundwater 
flow is governed by a set of differential equations (Wang and Anderson, 1982). These models are easy to use and equations can be modified to fit the nature of problem to which they are being applied. Mathematical models can be solved by two ways analytical methods and numerical methods (Freeze and Cherry, 1979). Analytical methods yield exact solutions by solving the differential equations by classical mathematical approaches (DOA, 1999). Since, field situations are too complex to be simulated precisely, a lot of simplifying assumptions such as assumptions of homogeneity and isotropy (Wang and Anderson, 1982) have to be made in order to solve a mathematical model analytically. Numerical methods, however, can include more complexities of the actual field situations. The availability of computers has also made it easier to solve the numerical models with much ease compared to the complex analytical methods. In numerical methods, the partial differential equations are approximated numerically by a computer to generate a set of algebraic equations, which are then solved to reach a solution (Anderson and Woessner, 2002).

There are a variety of numerical methods which are used in groundwater models. Amongst them, the finite-difference and finite-element methods are the mostly widely used methods. Both the methods use the concept of superposition of system of nodal points over the problem domain (Wang and Anderson, 1982). In the finite-difference method, the model domain is discretized into a rectangular grid consisting of a number of blocks, where each block is assigned its own hydrogeologic properties and has a node at the center where hydraulic head is computed for the entire block (Freeze and Cherry, 1979). The computed head at the node represents average head of the surrounding blocks (Anderson and Woessner, 2002). The values at each node are unique from its neighboring 
blocks, despite having an effect on the solution process from the adjacent blocks (DOA, 1999). The finite-element method, on the other hand, uses an irregular triangular or quadrilateral mesh where the corner points form the nodes (Freeze and Cherry, 1979). The areas delineated by connecting these nodal points by lines represent elements (Wang and Anderson, 1982). Instead of using finite-difference solution, this method uses equivalent variational function (Bouwer, 1978), where variation of head is precisely defined within an element by means of basis functions (Anderson and Woessner, 2002).

Selection of finite-difference or finite-element depends on the complexity of the flow system, problems of stability and truncation error, general applicability of computer programs, and preference of user (Bouwer, 1978; Anderson and Woessner, 2002). The finite-element method can represent irregular boundaries by flexible placement of nodes unlike the finite-difference method (Bouwer, 1978). Another major advantage of the finite-element method is that it is capable of providing a solution for two anisotropic formations in a flow field, each with different principal directions whereas the finitedifference method typically requires that principal directions of anisotropy in an anisotropic formation should match the co-ordinate axis (Freeze and Cherry, 1979). Despite these advantages of finite element methods, models based on them are not as widely used. Widespread use of finite-difference method around the world as well as reduced grid set-up time and less labor intensive grid set up gives finite-difference methods an edge over the finite-element method (DOA, 1999).

In this study, a predictive model has been used to forecast the behavior of the aquifer under different stress conditions such as change in recharge and abstraction conditions using finite-difference approach. But, before even attempting to model the 
area, one important question needs to be answered. Since the study area is located in a hard rock area, will it be relevant to model it using conventional modeling techniques used worldwide for porous media? The answer lies in the fact that immense simplification of conceptual model is required in such cases. In fracture flow models Darcy's law is applied by assuming that the fracture apertures and flow velocities are small (Anderson and Woessner, 2002). Since, hard rock areas are dominated by compact rocks having little to no primary porosity, groundwater flow is mainly controlled by joints, fissures, cracks, shear zones, etc forming secondary porosity (Srivastava and Bhattacharya, 2006). Three different conceptual models are available to model hard rock fractured system equivalent porous medium (EPM), discrete fractures, and dual porosity. In this case, EPM conceptual model is best suited because the details of fracture network and properties of porous blocks are not known. In the EPM concept, the medium or material is sufficiently fractured to act like a porous medium with large grains (Schwartz and Zhang, 2003). Groundwater modeling has previously been carried out successfully in many hard rock terrains with the EPM approach, but there is some disagreement on the nature of results. Some scientists have mentioned that EPM representation is not valid for fractured systems while others have mentioned that reasonable flow models can be constructed based on EPM concepts (Anderson and Woessner, 2002).

\subsection{Groundwater modeling studies}

Apart from some reports on the geology and hydrogeologic properties of the aquifer in and around the study area, there is no report on comprehensive groundwater modeling approach. However, numerous groundwater flow models have been developed 
in different parts of the world to simulate regional groundwater flow and to predict the behavior of the aquifers under various stress conditions.

Pisinaras et al. (2007) developed a regional flow simulation model of the streamaquifer system of Ismarida plain, northeastern Greece using MODFLOW. They observed a continuous decline in groundwater level especially after drought periods, and therefore, used the model to quantify the water budget based on a 3-year field study. Calibration of the model was achieved by a trial-and-error process of adjusting the initial approximation of aquifer properties and stresses until the best match between simulated and measured water levels was achieved. The calibration was justified using mean error, mean absolute error, root mean square error and normalized objective function. In addition to this, they formulated and tested four management scenarios with the model and came to a conclusion that a $33 \%$ decrease in withdrawals would stop the decline of groundwater level.

Idrysy and De Smedt (2006) addressed the problem of declining groundwater levels in Trifa, Morocco, caused by increase in groundwater withdrawals for irrigation by developing a steady-state groundwater model using MODFLOW in the PMWIN environment. On the basis of a water budget obtained from the model, they concluded that $25 \%$ reduction of abstraction of groundwater would be required to reach sustainable conditions.

Wen et al. (2007) developed a three-dimensional numerical groundwater flow model using FEFLOW (Finite Element subsurface Flow system) under transient conditions for Zhangye Basin in China, where extensive abstraction of groundwater for 
agricultural, industrial and drinking purpose led to a considerable decline of groundwater levels. The model was used to forecast drawdown over a period of 30 years.

It is well known that accuracy of any groundwater model is dependent on the availability and accuracy of extensive data sets. The more abundant and accurate the data sets are, greater are the accuracy of model results. However, Wiszniewski et al. (2007) have successfully calibrated a numerical flow model to understand groundwater flow pattern and impacts of increased groundwater recharge on land salinization in the $\mathrm{Xe}$ Champhone catchment in Savannakhet Province in Southern Lao People's Democratic Republic, despite having meager and limited data. A steady-state calibrated model was developed using PMWIN Pro, which was successful in achieving a good fit between the observed and simulated heads.

Another significant groundwater modeling work was carried out using Visual MODFLOW in Leon-Chinandega aquifer in Nicaragua by Palma and Bentley (2007). The region is predominantly dependent on groundwater for consumption and irrigation purposes owing to a prolonged dry season and unsuitable surface water due to contamination from agricultural chemicals and animal and human wastes. Both steadyand transient-state models were developed to study the flow system in the sub-basin of the Leon-Chinandega aquifer to study the groundwater system and to explore the effects of additional groundwater development on the aquifer. They concluded that the river base flow is affected by increased groundwater extraction particularly during the dry season, which in turn will affect the river-water quality. Additionally, both shallow and deep wells will be affected by the increasing abstraction of groundwater. 
Mace et al. (2000) developed a three-dimensional, numerical groundwater flow model of the upper and middle Trinity aquifer located in south-central Texas using MODFLOW-96 in PMWIN environment to estimate groundwater availability and water level response to pumping and future drought conditions. Steady- and transient-state models were calibrated successfully to reproduce the spatial distribution of water levels in the middle Trinity aquifer.

A study carried out in Esfahan hydrological province catchment in Iran showed that less availability of surface water in the region particularly during drought periods as well as heavy dependence on groundwater by people intensified the abstraction of groundwater leading to significant decline of the groundwater levels and quality. Gieske and Miranzadeh (2002) studied the movement of groundwater in the Lenjanat sub catchment. Following analysis of the available data on groundwater levels and abstractions, a conceptual model of the Lenjanat Southern Plains Aquifer was built which in turn was transformed into a steady state groundwater model using PMWIN as a preand post-processor for MODFLOW. The model was utilized to understand the relation between the main water balance components like average recharge, abstraction, inflow and outflow under steady state conditions.

A number of groundwater modeling studies have been done in India as well. Some of which are mentioned here. Ala Eldin et al. (2000) created a groundwater flow model to assess the degree of interaction between the Ganga River and aquifer in the Ganga-Mahawa sub-basin, which is a part of the Central Ganga Plain in Uttar Pradesh, India. Irrigation in this region is principally dependent on the groundwater resources. Abstraction from thousands of shallow and deep tube wells has resulted in the decline of 
groundwater levels. Future development of agriculture is threatened by an increase in the demand for more groundwater. Both steady- and transient-state models were developed using Visual MODFLOW. The aquifer properties were determined from morphometric analysis and pumping tests. The main input was natural recharge attributable to monsoon rainfall. Surface water levels and river bed elevations were assigned in the model using existing data. Abstraction from shallow and deep wells formed the main output of the model. June 1986 water levels were used to calibrate a steady-state model. The model was calibrated using trial and error process of adjusting the parameters until a good match was obtained between the observed and simulated heads. Mean error, mean absolute error and root mean square error were used to judge the accuracy of the simulated water levels. Additionally, a transient-state model was calibrated from June 1986 to May 1995. Simulated and observed well hydrographs were compared for 10 observation wells. It was concluded that groundwater discharge occurs to the rivers in the study area despite intensive groundwater exploitation, implying that there is further scope of groundwater development in the area.

Another study was done by Senthil Kumar and Elango (2004) in the lower Palar River basin in Tamil Nadu, India to effectively manage the groundwater resources. Groundwater Modeling System (GMS) developed by United States-Department of Defense was used as pre- and post-processor for MODFLOW. Steady- and transient-state calibrations of the model were carried out. The steady-state model showed a reasonable match between the observed and simulated heads. Transient-state model was run for a period of 10 years to predict flow under various aquifer stress conditions which included over-pumping and less recharge. 
Rejani et al. (2008) addressed the problem of overdraft and significant threat of sea water intrusion due to overexploitation of groundwater in Balasore Coastal Basin, India, in the form of a groundwater model using Visual MODFLOW, to efficiently manage groundwater in the region. After successful calibration of the model, it was used to simulate the response of the aquifer for five different pumping strategies under existing cropping conditions.

\subsection{Groundwater flow studies in fractured hard rock aquifers}

Most of the groundwater modeling work has been done in porous media. However, groundwater modeling in hard rock terrain is gaining popularity due to the challenges involved to model such areas. Some groundwater modeling studies related to hard rock areas are being mentioned here.

To address the problem of declining of declining water level due to excessive abstraction in Azraq Basin in Jordan, Abdulla et al. (2000) developed a three-dimensional finite-difference model using MODFLOW in PMWIN environment to simulate groundwater flow and predicted the behavior of groundwater levels affected by excess abstraction. They developed a 4 layer model. The model was calibrated for both steadyand transient states over the period of 1970-1992. Four management scenarios were also developed to predict the aquifer responses. They showed that water levels can drop by $39 \mathrm{~m}$ if pumping rate is increased by 1.5 times that of present rate.

Rivera (2002) developed a numerical groundwater model using Visual MODFLOW to gain insight into the complexity of groundwater flow in order to determine the origin and dispersion path of nitrate contamination in the wells of Urania in 
Brazil. The model included two layers - a sandstone aquifer and a fractured basalt aquifer. He found that the aquifer had both horizontal and vertical heterogeneity and that the flow in the aquifer is very complex. He mainly focused on the groundwater movement rather than quantifying the available amount of water.

Yihdego (2005) developed a steady-state numerical groundwater model for Lake Navaisha and the surrounding aquifer in Kenya to simulate groundwater flow in the aquifers and lake-aquifer interaction in a hard rock terrain. A four-layer model was developed using groundwater modeling system (GMS 5.0) in which the upper two layers represented sedimentary aquifers and the lower two layers represented fractured volcanic aquifers. In order to model the fracture hard rock aquifers, a continuum approach was undertaken where the medium is considered to be porous and, therefore, Darcy's law is applicable. The simulated heads were comparable to the observed heads and the important aspects of flow system such as magnitude and direction of the head contours were replicated successfully. He concluded that Lake Navaisha strongly influences the surrounding aquifers.

\subsection{Delineation of recharge areas using remote sensing and GIS}

Most of the regions in Rajasthan fall into arid or semi-arid zones where the availability of surface water resources is meager. Groundwater has been the major source of fresh water in these regions. The availability of groundwater is particularly limited in areas existing in hard rock terrains where occurrence and movement of groundwater is controlled by secondary porosity developed by weathering and fracturing of rocks (Saraf et al., 1998; Rao, 2006; Srivastava and Bhattacharya, 2006). The existence of 
groundwater depends on a number of factors like lithology, topography, landform, land use, drainage, etc. All these factors are extremely important to locate groundwater as these factors affect the recharge of groundwater. In Rajasthan, the hard rock aquifers located in high and rigid topography, receive less recharge due to scanty rainfall in addition to high runoff induced by high slopes. In order to exploit these aquifers sustainably even during drought times, it is important to recharge these aquifers sufficiently. Besides, many Government and Non-Governmental Organizations (NGO) are working closely with people in these areas to induce artificial recharge by the construction of various artificial recharge structures to augment groundwater resources. It is, therefore, extremely important to determine the location of suitable recharge areas so that groundwater can be extracted sustainably without hampering the quality and quantity of groundwater and also to ensure the success of the artificial recharge structures.

Satellite data used in conjunction with Geographic Information System (GIS) techniques have proved to be very beneficial for identification of recharge areas. Multispectral, multi-temporal and multivariate datasets of the Earth's surface can be obtained from satellite images (Saraf et al., 2004) quickly and reliably for better observation and systematic analysis (Kumar et al., 2006, Rao, 2006). These datasets provide important information on the spatial nature of geology, land use/land cover, drainage, etc. that exists at a particular time in a given area (Jaiswal et al., 2003). Additionally, remote sensing can be used to demarcate the surficial and sub-surface features which provide vital clues in understanding the groundwater movement and localization (Jaiswal et al., 2003). This gives remote sensing an edge over conventional methods of exploration where varied factors controlling the occurrence and movement of groundwater are 
sometimes not taken into account and the process involves lot of time, man power and money.

Geographic Information System (GIS) provides the ease of working with vast amounts of multi-disciplinary data which include both spatial and non-spatial data sets (Saraf et al., 1998). In addition, GIS has the capabilities of storing large datasets efficiently and systematically and also has numerous tools for systematic analysis of spatial data from diverse sources (Saraf et al., 2004). Thus, GIS and remote sensing used together could be very useful to find accurate information in very short time.

There have been many studies involving the integration of GIS and remote sensing to identify suitable recharge areas in hard rock terrains, some of which are mentioned in this section. Saraf et al. (1998) used remote sensing in conjunction with GIS to identify artificial recharge sites in Sironj area of Vidisha district of Madhya Pradesh, India. In this study, satellite data were used to generate thematic maps of geology, geomorphology, lineament, land use and Normalized Difference Vegetation Index (NDVI). An existing map of topography was used to generate a base map and Digital Elevation Model (DEM) of the area. All the thematic maps were then analyzed in a GIS environment together with water level map to find out suitable artificial recharge sites based on defined logical criterion of analysis. Finally, a set of weights were assigned to different parameters based on their relative contribution to facilitate recharge. Similar studies were carried out by many scientists to delineate groundwater potential zones in different parts of the country (Saraf et al., 2004; Kumar et al., 2006; Jaiswal et al., 2003; Rao 2006; Anbazhagan et. al., 2005; Krishnamurthy et al., 2000; Srivastava and Bhattacharya, 2006; Ravi Shankar and Mohan, 2006). 


\subsection{DESCRIPTION OF STUDY AREA}

General characteristics of the Wakal River basin and the study area are discussed in this chapter. Separate discussions are provided on features that are highly correlated to groundwater. Descriptions of meteorological parameters are presented after analysis of necessary data from the Groundwater Department, Rajasthan and Maharana Pratap University of Agriculture and Technology (MPUAT), Rajasthan. Published maps and various reports have been used to shed light on hydrology, geomorphology, and geology.

\subsection{Location of study area}

The Wakal River (Figure 3-1) is one of the five main tributaries of the River Sabarmati - a $371 \mathrm{~km}$ long trans-boundary river that flows southward through the states of Rajasthan and Gujarat and discharges into the Gulf of Cambay in the Arabian Sea (ICID, 2005). The river originates in north-west of Udaipur in the Aravalli Hills, with Mansi and Parvi Rivers as the two main tributaries (Chauhan, 2007). The total catchment area of the Wakal River is $1900 \mathrm{~km}^{2}$. Due to limited scope of the study, the entire Wakal catchment could not be investigated for groundwater modeling purpose. Rather, a small catchment located in the southern part of Wakal River basin was investigated where the groundwater demand is high for domestic and agricultural purposes (Fig. 3-1). The study area catchment lies between the latitudes of $24^{\circ} 11.4^{\prime}$ and $24^{\circ} 20.1^{\prime}$ and the longitudes of $73^{\circ} 19.8^{\prime}$ and $73^{\circ} 27.3^{\prime}$ with a total catchment area of $118 \mathrm{~km}^{2}$. 


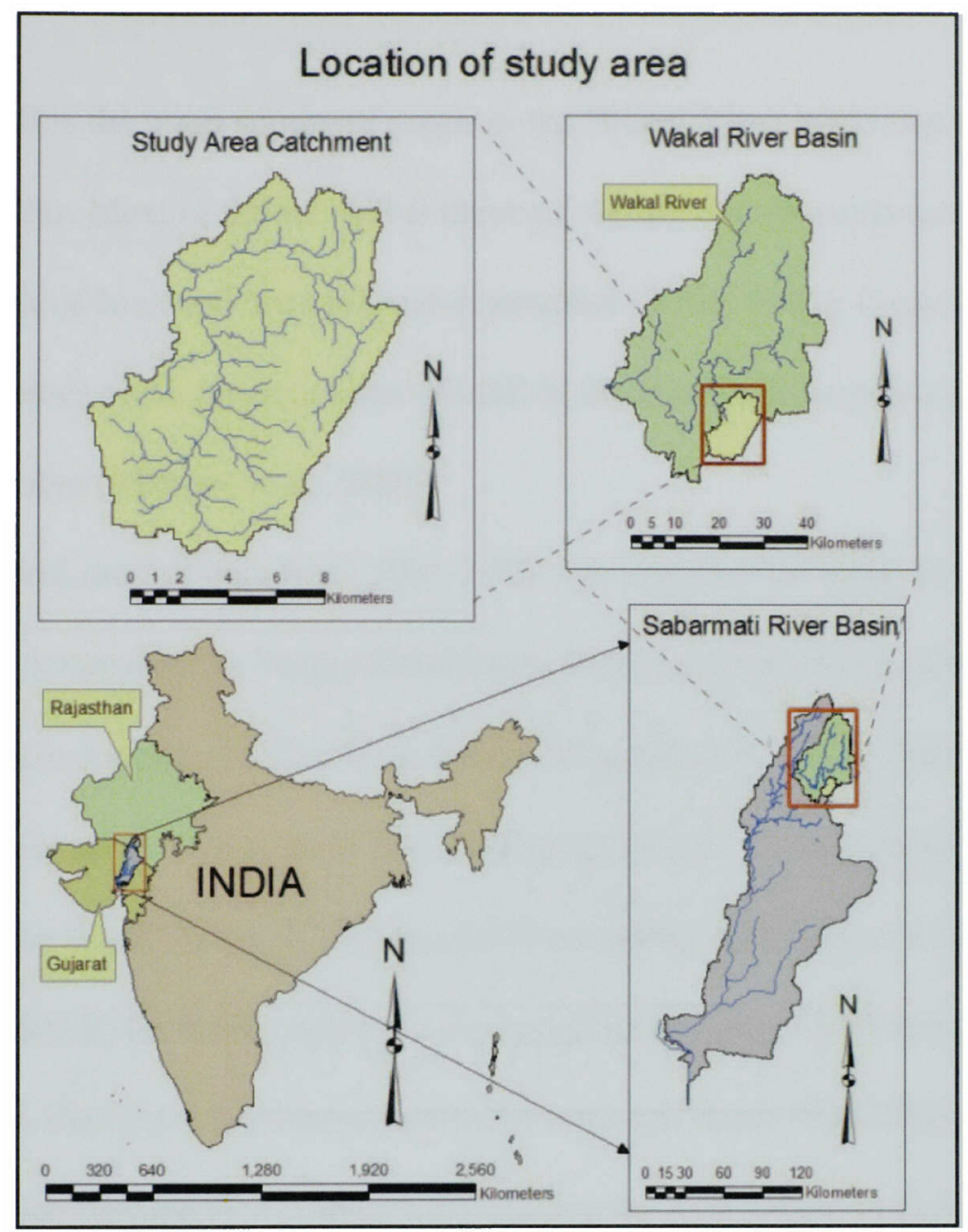

Figure 3-1. Location of study area.

\subsection{Climate}

The Wakal River basin lying in the Aravalli Hills in south-eastern Rajasthan has a semi-arid to sub-humid climate (Narain et al., 2005). This area is characterized by extreme diurnal and annual temperatures, low wind velocity, high humidity and good rainfall (Rathore, 2005b). This basin experiences 3 distinct climatic seasons - wet season from late June to September (also known as monsoon or kharif), winter season from October to February (rabi), and hot summer season from March to mid-June. 


\subsubsection{Rainfall}

Rainfall is the main source of water in the Wakal River basin and varies sharply from year to year. Most of the rainfall is received during the monsoon season which starts in the last week of June and lasts till mid-September (ICID, 2005). Occasionally, the basin also receives some pre-monsoon rainfall in the middle of June and post-monsoon rainfall in October (Mahnot et al., 2003).

Historical rainfall data from 1965-2005 was acquired for three of the five rain gauge stations located in the Wakal River basin from the Groundwater Department, Rajasthan. These stations are located in Jhadol, Gogunda and Kotra. Only rainfall data from Jhadol rain gauge station have been analyzed because about $52 \%$ of the Wakal Basin lies in the Jhadol block (Chauhan, 2007) including the study area catchment. It was found that Wakal River basin receives a mean annual rainfall of $645 \mathrm{~mm}$. Talking about the recent past, the area experienced continuous drought from 1999-2004. Meteorological drought has been defined by National Commission on Agriculture in India as a situation where the precipitation over an area decreases from normal by more than 25\% (Rathore, 2005a). The annual rainfall distribution is shown in Figure 3-2. The statistical analysis of monthly rainfall data was also performed (Figure 3-3), and it was found that the rainfall distribution pattern is unimodal with most of the rainfall occurring in the month of July with an average of $224.6 \mathrm{~mm}$ of rainfall in that month. A summary of statistics for rainfall data has been provided in Appendix 1. However, complete rainfall data for the year 2006 were not available from the Groundwater Department. Instead, daily rainfall data for the year 2006 were acquired from Maharana Pratap University of Agriculture and Technology (MPUAT), Udaipur, India (Singh, Unpublished data, 2006). MPUAT is 
located in Udaipur which is approximately $80 \mathrm{~km}$ north from the study area. For modeling purposes, rainfall data obtained from MPUAT have been used. This was done because MPUAT had complete rainfall dataset for the year 2006. Moreover, since Udaipur is not very far from the study area, the rainfall data could be used as a representative data for the study area. Total rainfall in Udaipur was recorded to be 984.3 mm for 2006.

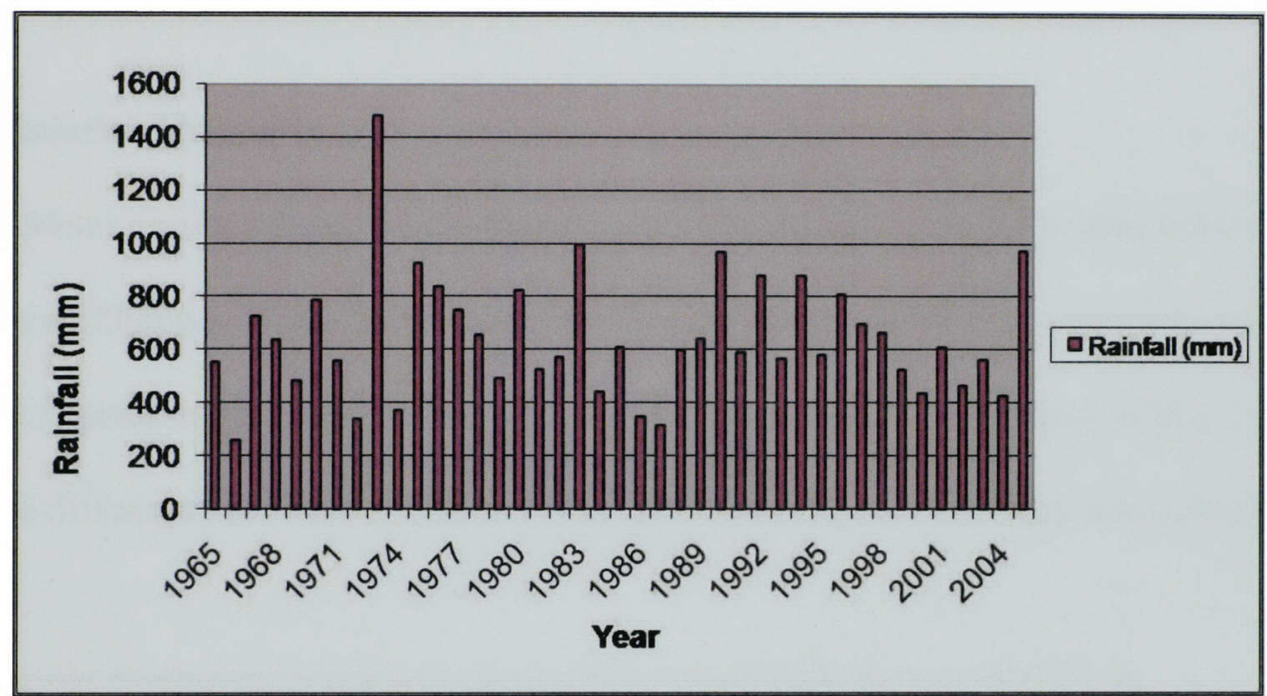

Figure 3-2. Annual rainfall distribution in the Wakal Basin (1965-2005).

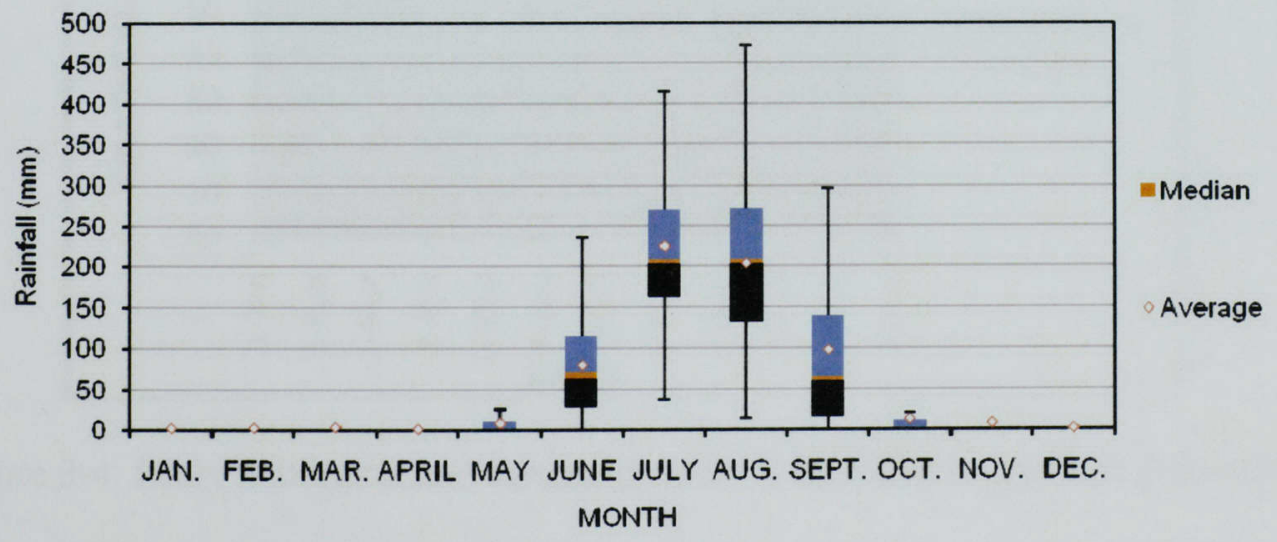

Figure 3-3. Mean monthly rainfall distribution in the Wakal Basin (1965-2005). 


\subsubsection{Temperature}

Average annual temperature in Sabarmati River basin ranges from $25^{\circ} \mathrm{C}$ to $27.5^{\circ}$ C (ICID, 2005). For the year 2006, maximum temperature recorded in the Wakal basin was $42^{\circ} \mathrm{C}$ in May while minimum temperature was $2.5^{\circ} \mathrm{C}$ in January (Singh, Unpublished data, 2006). Variations of monthly temperature for 2006 are provided in Appendix 2.

\subsubsection{Relative Humidity}

Mean maximum and mean minimum relative humidity in the Wakal River basin in the year 2006 were $78 \%$ and $41 \%$ respectively. Relative humidity, both maximum and minimum, peak in the monsoon season (June to September) as is evident in Fig. 3-4. Average difference between maximum and minimum relative humidity was calculated to be $37 \%$.

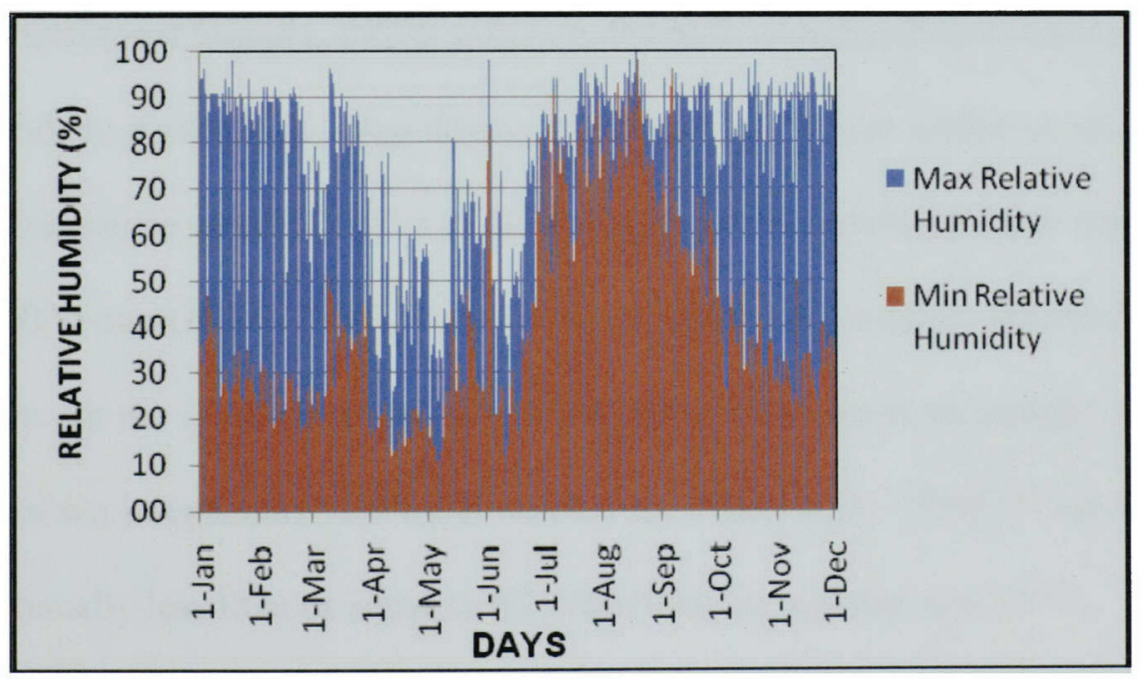

Figure 3-4. Daily maximum and minimum relative humidity in the Wakal Basin for 2006. 


\subsubsection{Evapotranspiration}

The term evapotranspiration (ET) is a combined term used for evaporation and transpiration. Evaporation and transpiration are two separate processes but both are related to loss of water to the atmosphere. In hydrological studies, evaporation refers to transformation of water to water vapor (Schwartz and Zhang, 2003) whereas the process of losing water to the atmosphere by plants and trees is known as transpiration (Davis and De Wiest, 1996). The two processes are accounted for together because both the processes occur simultaneously and it becomes very hard to distinguish between the two processes (Allen et al., 1998). In most hydrological studies, ET is reported either as reference crop ET (also know as Potential ET) or crop ET under standard conditions (usually referred to as Actual ET). Reference crop ET, denoted by ET, is the evaporation of water from a reference crop surface of uniform elevation that fully shades the ground, usually alfalfa or short grass, and there is sufficient water to meet their needs (McWhorter and Sunada, 1977). $\mathrm{ET}_{\mathrm{o}}$ is affected by climatic factors only and is independent of crop type, crop development and soil factors (Allen et. al., 1998). Average annual reference crop ET ( $\left.\mathrm{ET}_{\mathrm{o}}\right)$ in the Sabarmati River basin has been reported to be 1500-2000 mm (ICID, 2005). Crop ET under standard condition, denoted by $\mathrm{ET}_{\mathrm{c}}$, accounts for the field conditions where evaporation occurs from healthy, well fertilized crops grown in optimum soil water conditions (Allen et al., 1998). It has been noted that $\mathrm{ET}_{\mathrm{c}}$ is usually less than or equal to $\mathrm{ET}_{\mathrm{o}}$ (McWhorter and Sunada, 1977).

An attempt was made to compute $\mathrm{ET}_{\mathrm{o}}$ in the Wakal Basin. In this study, reference crop ET $\left(E_{0}\right)$ was calculated using Penman-Monteith method which was modified by Food and Agriculture Organization (FAO) of the United Nations (Allen et al., 2008). This 
method requires various climatic data such as sunshine duration, air temperature, wind speed, soil heat flux, and others and can be used to compute $\mathrm{ET}_{\mathrm{o}}$ on daily, weekly, tenday or monthly time frame. The modified Penman-Monteith equation (Equation 3-1) for reference crop $\mathrm{ET}\left(\mathrm{ET}_{0}\right)$ is

$$
E T_{o}=\frac{0.408 \Delta\left(R_{n}-G\right)+\gamma \frac{900}{T+273} u_{2}\left(e_{s}-e_{a}\right)}{\Delta+\gamma\left(1+0.34 u_{2}\right)}
$$

where,

$$
\begin{array}{ccc}
E T_{0} & : & \text { reference evapotranspiration }\left[\mathrm{mm} \mathrm{day}^{-1}\right] \\
R n & : & \text { net radiation at the crop surface }\left[\mathrm{MJ} \mathrm{m}^{-2} \text { day }^{-1}\right] \\
G & : & \text { soil heat flux density }\left[\mathrm{MJ} \mathrm{m}^{-2} \mathrm{day}^{-1}\right] \\
T & : & \text { mean daily air temperature at } 2 \mathrm{~m} \text { height }\left[{ }^{\circ} \mathrm{C}\right] \\
u_{2} & : & \text { wind speed at } 2 \mathrm{~m} \text { height }\left[\mathrm{m} \mathrm{s}^{-1}\right] \\
e_{s} & : & \text { saturation vapor pressure }[\mathrm{kPa}] \\
e_{a} & : & \text { actual vapour pressure }[\mathrm{kPa}] \\
e_{s}-e_{a} & : & \text { saturation vapor pressure deficit }[\mathrm{kPa}] \\
\Delta & : & \text { slope vapor pressure curve }\left[\mathrm{kPa}{ }^{\circ} \mathrm{C}^{-1}\right] \\
\gamma & : & \text { psychrometric constant }\left[\mathrm{kPa}{ }^{\circ} \mathrm{C}-1\right]
\end{array}
$$

\subsection{Hydrology}

\subsubsection{Surface water bodies}

The major rivers which flow through the Wakal River basin are the Wakal, Mansi and Parvi rivers. All the rivers and streams in the basin are typically storm channels and 
are, therefore, ephemeral in nature and dry up usually after the monsoon season (Kumar et al., 1999). Additionally, there are numerous ponds, lakes and other small reservoirs scattered throughout the Wakal basin as well as in the study area. Total average annual surface water resources for the Rajasthan portion of the Sabarmati Basin which includes the Wakal River basin has been reported to be 513 million cubic meter (MCM) by Department of Irrigation, Rajasthan (ICID, 2005).

\subsubsection{Water balance of the catchment}

The difference between water gains to the catchment and water losses from the catchment during a specified period is termed the water budget. Water budgets can be of two types: the hydrologic water budget includes inflow and outflow of surface as well as groundwater component of the catchment whereas groundwater budget includes inflow and outflow of groundwater only. Usually crude water budgets are calculated for a catchment under steady state conditions where it is assumed that the change in storage will be equivalent to zero. This approach is beneficial because it provides a general idea about the gains and losses of the catchment. It has to be noted that each estimation technique has its own limitations. Temporal and spatial aspects of various parameters such as recharge, evapotranspiration, discharge, etc., are however not represented in this lumped parameter approach.

However, both hydrologic and groundwater water budgets for the study area could not be calculated using lumped parameter approach as discharge data were not available for the area. 


\subsection{Geomorphology}

The geomorphology of the Wakal River basin and the study area catchment is largely governed by the geologic history, rock types and structure. The Wakal basin lies in the Aravalli hill physiographic region of Rajasthan where the areas are dominantly hilly and undulating (GOR, 2003). The elevation of topography in the Wakal River basin ranges from $263 \mathrm{~m}$ to as high as $1167 \mathrm{~m}$ above sea level (asl) (Figure 3-5). The study area is located in a hilly terrain with elevations ranging from $486-995 \mathrm{~m}$ asl (Figure 3-6). The morphological features in the basin as well as the study area include pediments, buried pediments and structural hills which are mostly of denudational origin with presence of valley fills of fluvial origin in some areas (GOR, 2003).

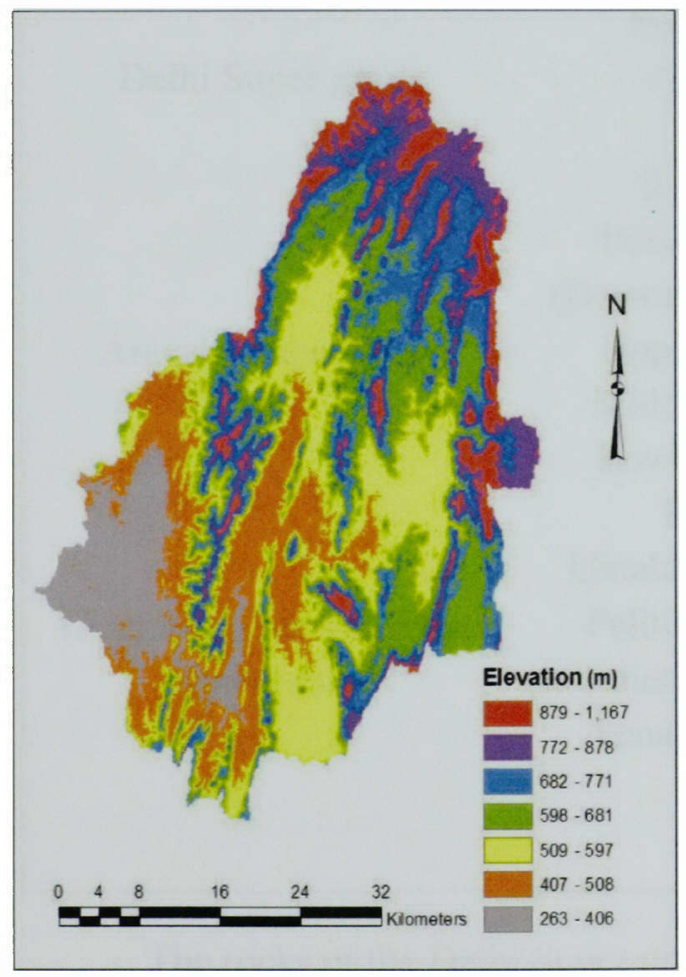

Figure 3-5. Elevation map of Wakal basin.

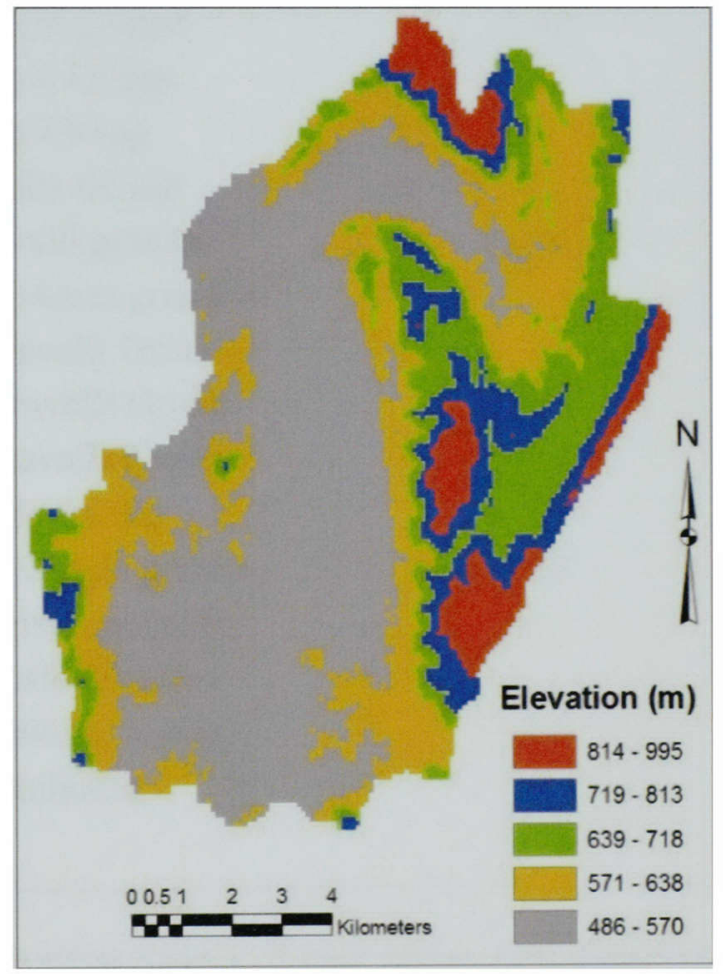

Figure 3-6. Elevation map of study area. 


\subsection{Geology}

The Wakal River originates in one of the oldest mountain range of the world, the Aravalli Mountains. The geology of the Wakal River basin is essentially comprised of metamorphic rocks of Pre-Cambrian age, belonging to the Delhi Super group and Aravalli Super group of the Aravalli Mountains underlain by Archaean basement (Mohemmad, 1993). A detailed stratigraphic succession is presented in Table 3-1.

Table 3-1. Stratigraphic succession of the Aravalli Mountains (After Roy, 1988). Source: Mohemmad, 1993.

\begin{tabular}{|ccc|}
\hline Super group & Sub-group & Age (billion years) \\
Vindhyan Super group & Malani rhyolite suite & 0.75 \\
& Erinpura granite and Godra & $0.75-0.90$ \\
& granite & \\
& Champaner Group & 1.45 \\
Delhi Super group & Post-Delhi granite & \\
& Ajabgarh Group & \\
& Alwar Group & 1.9 \\
& Ryanhalla Group & \\
Aravalli Super group & Post-Aravalli granites & \\
& (Darwal and Amet granites) & \\
& Upper Aravalli Group & \\
& Middle Aravalli Group & \\
& Lower Aravalli Group & 3.6 \\
& Berach granite & \\
& Untala and Gingla granite & 3.5 \\
(Archaean) Mewar gneiss & Pelitic gneiss, quartzite, & \\
and granite & marble, calc-silicates & \\
& Tonalitic biotite gneiss, & \\
& amphibolite & \\
\hline
\end{tabular}

The rocks of the Delhi Super group consist mainly of calc schist, calc gneiss and limestone with a general strike of northeast-southwest and dip towards the northwest and the southeast (Kumar et al., 1999). The thick formation of the Aravalli Super group is 
essentially comprised of basal quartzite, shales, conglomerates, composite gneisses and slates (Chauhan, 2007). The rocks of the Wakal basin are highly fractured which can be explained by polyphase deformation experienced by these rock sequences during the orogenic phase of formation of the Aravalli Mountains.

The geology of the study area catchment, however, can be related to Aravalli Super group only and more specifically to the Jharol Group, which is geologically the youngest group of Aravalli Super group (Mohemmad, 1993). The stragraphic succession has been provided in Table 3-2. Major rock types of the Jharol group include phyllites, chlorite-schist, garnetiferous mica-schist, intercalatory quartzite and minor lenses and bands of calc-schist and marble (Mohemmad, 1993). The grade of metamorphism of the Jharol group varies from low green-schist facies to low amphibolite facies (Prasad et al., 1997).

Table. 3-2. Stratigraphic succession of the rocks in the study area catchment. Source: Chauhan et. al., 1996.

\begin{tabular}{|c|c|l|c|}
\hline Super group & Sub-group & Formation & Rock type \\
\hline Aravalli Super & Upper Aravalli & Jharol Formation & Pegmatite/Quartz \\
group & Group & & vein \\
& & & $\begin{array}{c}\text { Quartzite } \\
\text { Garnet-mica schist }\end{array}$ \\
\hline
\end{tabular}

Chauhan et al. (1996) investigated the geology of a small area near Gorimari, which coincidentally lies in the study area catchment, and found that the major rock types in this area comprise of two dominant metasediments: (i) schistose rock with compositional variations, and (ii) quartzitic rock of varied thickness (Fig. 3-7). 


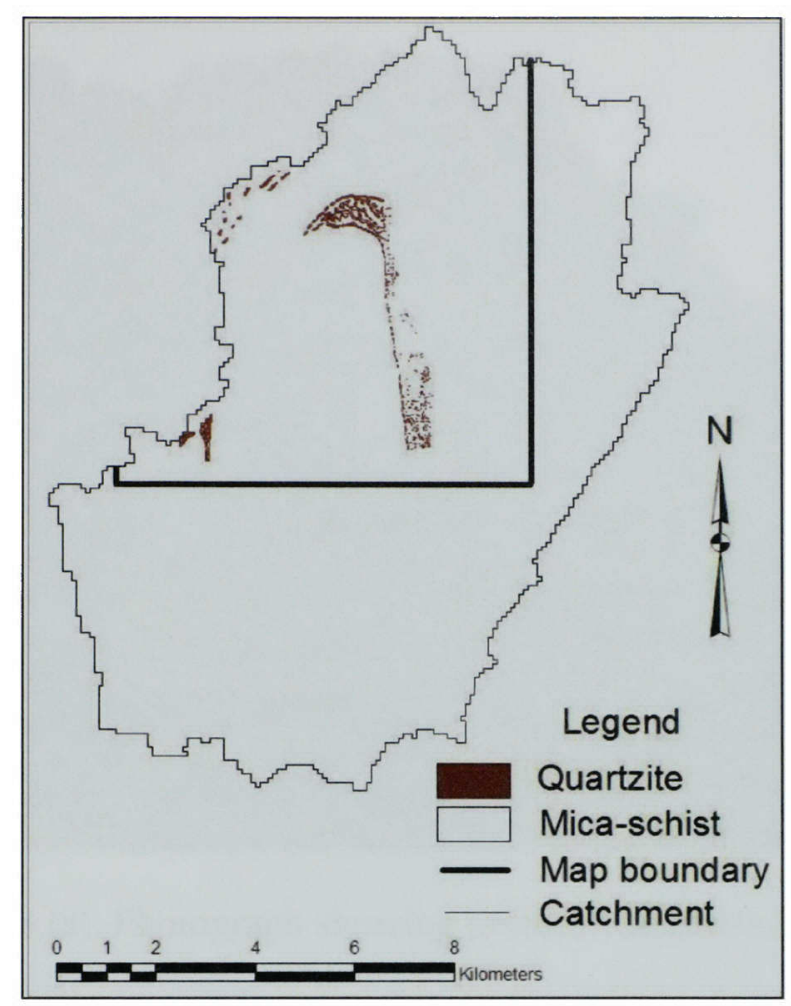

Fig. 3-7. Lithology of study area catchment.

\subsection{Hydrogeology}

Groundwater in the Wakal basin, including the study area catchment, exists mostly in unconfined aquifers formed by highly weathered and fractured rocks (Kumar et. al., 1999) of the Delhi and Aravalli Supergroups. In addition, alluvium aquifers have also been found in some places (Chauhan, 2007). However, the presence of alluvium aquifers are not known in the study area. The hard rocks essentially lack primary porosity and, therefore, movement of groundwater is mainly controlled by structural features developed within the hard rocks especially cleavages, fractures and joints (Fig. 3-8 (a) and (b)). 


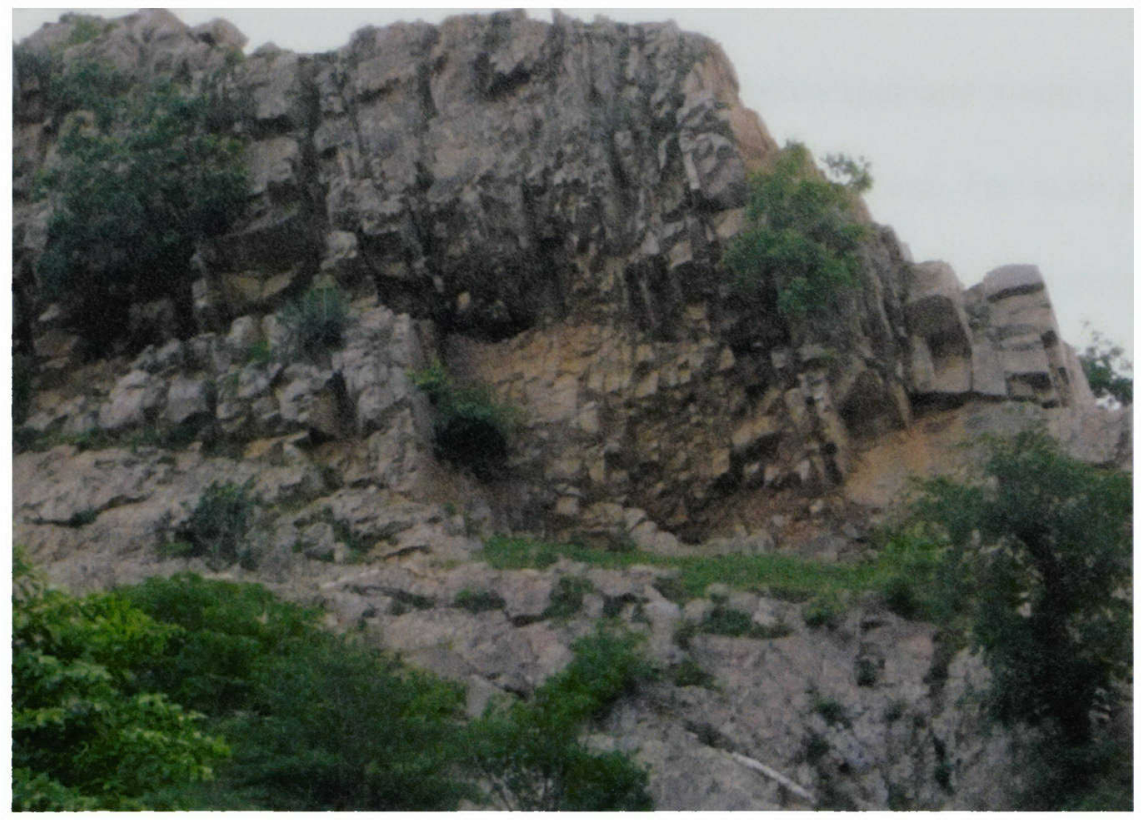

Fig. 3-8 (a). Photograph showing joints in Quartzitic rocks.

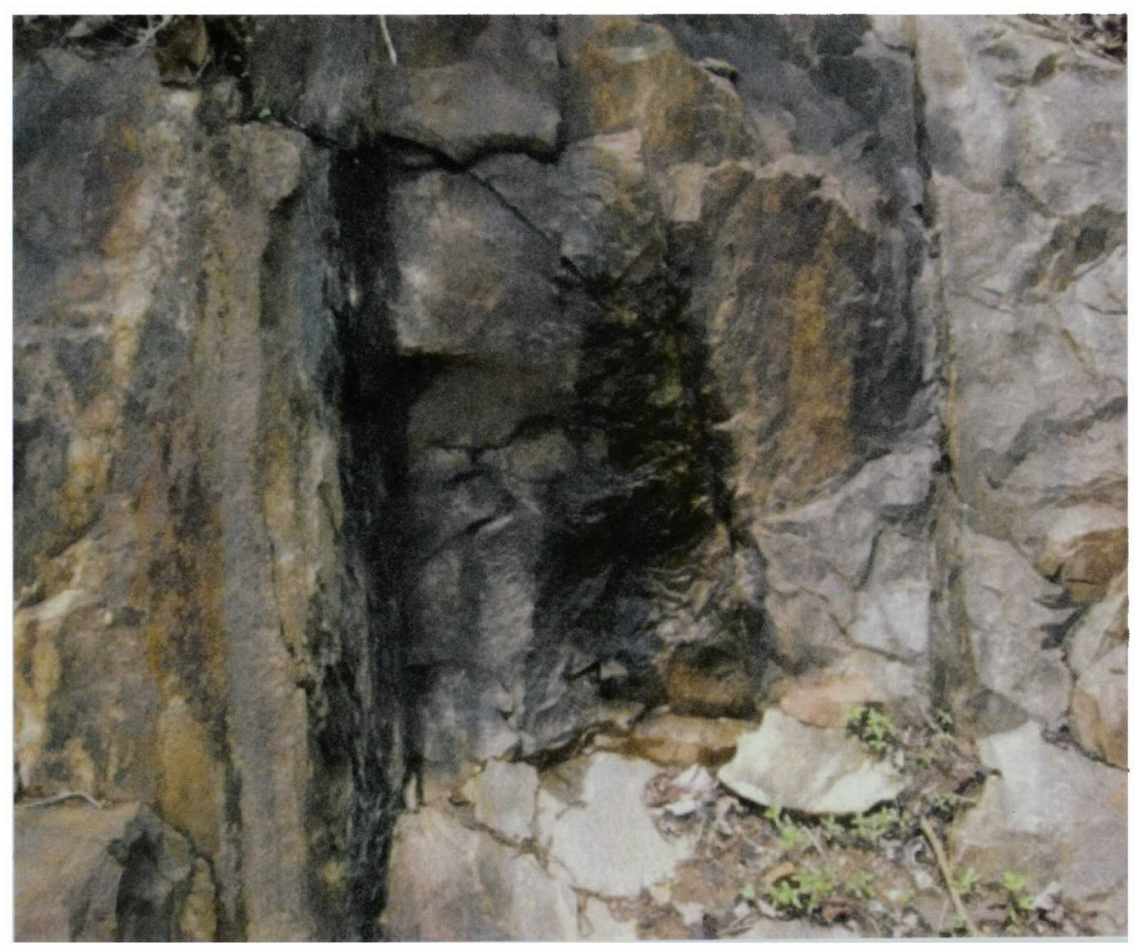

Fig. 3-8 (b). Photograph showing groundwater seeping through joints and fractures. 


\subsection{Water use}

Water use depends on population, water availability (surface water/ground water), water use patterns (domestic, agriculture, industrial), and land use. The total population in the Wakal basin has been reported to be approximately 260,000 with a population density of 134 persons per $\mathrm{km}^{2}$ (AFPRO, 2007). Average population density in the study area catchment (represented by Jhadol block) is 199 persons per $\mathrm{km}^{2}$ (AFPRO, 2007). The entire population is rural and, therefore, depends on agriculture for their livelihood (ICID, 2005). Because of an absence of perennial surface water resources, people living in the Wakal basin primarily depend on ground water for all their needs, especially agriculture. About $11 \%$ of the total area in the Wakal basin is used for agricultural purposes but forests and open land form the dominant land use/cover (AFPRO, 2007). Varieties of crops are grown in this basin which includes maize, sorghum, groundnut, cotton, black gram, wheat, barley, gram and mustard. Maize is grown in the monsoon season which mainly depends on rainfall. However, the rabi crops (winter crops) which include wheat and barley cover the majority of the agricultural area and require groundwater (Mahnot et al., 2003). 


\subsection{METHODOLOGY}

This chapter describes collection and analysis of various data that will be used as input to the numerical groundwater model and for delineation of groundwater recharge areas. First, a detailed description of fieldwork carried out in the study area is discussed in section 4.1 , followed by an evaluation of aquifer properties based on a pumping tests in section 4.2. Details about recharge are presented separately in section 4.3. In section 4.4 , the concept of groundwater modeling is discussed briefly followed by the formulation of a conceptual model based upon available field measurements and ancillary data in section 4.5 , and then selection of appropriate groundwater modeling type, modeling code, and processor for the stated purpose is outlined in section $4.6,4.7$ and 4.8 respectively. Section 4.9 describes the formulation of model design and data input into the numerical model. A detailed methodology used for delineation of recharge areas with remote sensing and GIS is presented in the section 4.10 of this chapter.

\subsection{Field data collection program}

Fieldwork was carried out from May to July in 2006 to collect data on meteorology (rainfall, air temperature, humidity, etc.), groundwater and geology (for groundwater level, well characteristics, and groundwater extraction). The wells are widely distributed throughout the area. Data collection was carried out with the assistance of local collaborators with knowledge of the area as well as locations of wells. In order to accomplish the fieldwork in a little over two months, 2-4 days in each week were spent in the field. A total of 187 wells were investigated. Well data collected include depth to water table, well diameter, total well depth, approximate estimation of groundwater 
withdrawal from each well and purpose of groundwater use. The details about these are provided in separate sections below.

Additionally, pumping tests at different locations in the study area were also carried out to determine aquifer properties. In addition to field data, available ancillary data were also been obtained from various institutions such as the Groundwater Department, Rajasthan and MPUAT, Udaipur, Rajasthan during this period. Field data were used together with ancillary data for the development of a conceptual model for the numerical groundwater model.

\subsubsection{Wells}

Wells form the backbone of water supply in the area, both for domestic and irrigation purposes. These wells are mostly large open dug wells, which are basically excavated pits through the top soil layer and weathered rocks (Figure. 4-1).

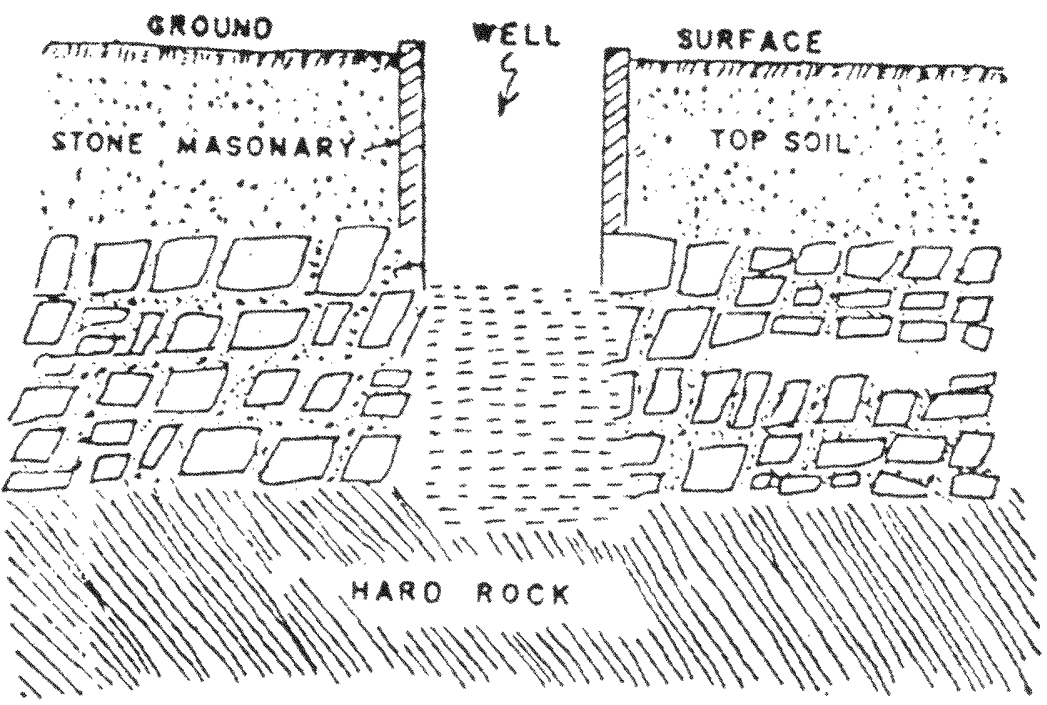

Figure 4-1. Open dug wells. (Source: CGWB, 1986) 
The objective behind construction of such large wells is to provide storage of groundwater and also to exploit more joints, cracks and fissures that are the water bearing formations (CGWB, 1986). Yield of these wells depends on weathered zones, joints, and cracks and are mostly low, but some wells that include a large number of water bearing formations having large secondary porosity can have very high yields (CGWB, 1986). The diameters of the wells were measured with a measuring tape. The diameters of the wells are presented in Appendix 3. The well depths were measured using a measuring tape with a small weight attached at one end and are presented in Appendix 4. Well depth measurements were taken relative to the ground surface. Statistics of well diameter and total well depth are presented in Table 4-1.

Table 4-1. Statistics of well diameter and total well depth.

\begin{tabular}{|c|c|c|}
\hline & Well diameter $(\mathrm{m})$ & Well depth $(\mathrm{m})$ \\
\hline Min & 2.75 & 1.85 \\
\hline Max & 10 & 20.1 \\
\hline Mean & 5.6 & 11.6 \\
\hline
\end{tabular}

\subsubsection{Groundwater level}

Groundwater level measurements are extremely important for any hydrological study and especially for developing a numeric groundwater model. They provide a variety of information about hydrogeological conditions of the catchment and its groundwater regime. Furthermore, the observed groundwater levels are used to calibrate numeric groundwater models for both steady and transient states. 
Groundwater level measurements for the pre-monsoon and monsoon period were recorded. Single measurements of pre-monsoon groundwater levels were collected from 187 wells between 22 May 2006 and 10 June 2006. These wells are mostly abstraction wells and are used by people on a daily basis. Single measurements of monsoon groundwater levels were obtained from the same wells between 19 July 2006 and 27 July 2006. Since there are no monitoring wells in the area, out of 187 wells, 19 abstraction wells were selected for intensive monitoring of groundwater levels during the fieldwork period. Groundwater levels were measured in these wells once a week during the monsoon period. While measuring groundwater level for the pre-monsoon period, a reference point was identified and marked on the well using paint. This was required to make sure that groundwater level measurements for pre- and during-monsoon period were measured from the same reference point. Then, a Magellan Meridian global positioning system (GPS) device was placed on the reference point to record location, elevation of the surface and name of wells. Elevations were recorded while taking both pre- and post-monsoon measurements and were averaged out for the calculation of groundwater level. Following that, depth to the water table was measured from the reference point using Solinst water level meter (model\# 101). The reading for depth to water table was then subtracted from elevation recorded by GPS to compute the groundwater level in meters above sea level.

\subsubsection{Groundwater extraction}

During well surveys, data on the approximate extraction volumes were obtained by interviewing the owners of the wells and people who use the wells. They were asked 
questions about approximate groundwater usage for domestic, cattle and other domestic animals, and irrigation needs. Specific information regarding summer and winter irrigation needs was also collected based on the type and capacity of water pump installed in the wells and total duration of pumping per day. It was observed that people highly depend on their wells for livelihood. All water needs are met from these wells for domestic, drinking, and irrigation purposes. Cattle and other domestic animals are also provided water from these wells. However, not all wells are used for drinking and domestic purposes. Wells lying in the fields are especially used for irrigation purposes only. Almost all wells are fitted with either diesel or electric water pumps or both to withdraw water and are used especially to water their fields during the winter (rabi) dry season. In the summer season, groundwater levels go down and the pumps are usually removed. At that time, groundwater is withdrawn using a bucket and rope suspended from a pulley.

\subsection{Evaluation of aquifer properties}

Aquifer properties such as transmissivity and storativity provide vital information on aquifer behavior. These properties are especially helpful in determining the ease of flow of groundwater through the aquifer and the amount of groundwater that can be stored in the aquifer, respectively. Pumping tests, which are commonly used worldwide, were used to determine these properties in the study area. Pumping tests can be categorized into aquifer tests and yield tests. The aquifer tests are used to determine the hydraulic characteristics of an aquifer whereas the yield tests are used to determine yield and drawdown of a well (CGWB, 1986). 
Two aquifer tests were performed in the study area. The aquifer test procedure involves pumping groundwater from a dug well at a constant discharge rate for a certain time and measuring the drawdown rate in the pumped dug well and observation wells in the vicinity of the pumped well. In the same way, recovery rates are also recorded for the pumped dug well and observation wells after pumping has stopped. Then, drawdown and recovery data are analyzed using an appropriate method.

Aquifer tests were performed in the villages of Shyampurakala and Amor on 07/18/2006 and 07/20/2006 respectively. A diesel water pump was used to withdraw water from the dug well. A flow meter was set at the end of this pipe to measure the discharge. The discharge rate was caclculated as $0.479 \mathrm{~m}^{3} /$ minute at Shyampurakala aquifer test and $0.527 \mathrm{~m}^{3} /$ minute at Amor aquifer test. However during the aquifer test, it was noted that there was no effect on the observation wells. Drawdown from the pumped well were plotted against logarithm of time and were analyzed using Cooper-Jacob straight line method to quantify transmissivity. The drawdown data for the two aquifer test locations are presented in Appendix 5.

\subsection{Recharge}

Recharge is one of the most important components that need to be considered in hydrological study. Water entering the dynamic groundwater flow system after percolating through the unsaturated zone is commonly referred to as recharge (Schwartz and Zhang, 2003).

Proper understanding of recharge and discharge processes together with their inter-relationship with geological, geomorphological, soil, land-use and climatic factors 
are required to estimate groundwater recharge. The aquifer in the study area is recharged mainly by precipitation during the monsoon season. However, in the dry season, especially in the winter (rabi season), the aquifer is partly recharged by irrigation return flow.

To quantify recharge in the study area, natural recharge estimates from the existing literature and groundwater modeling were used. Natural groundwater recharge estimates in various hard rock terrains have been made using various techniques in different parts of India (Paralta and Oliviera, 2005; Srinivas et al., 1999; Sukhija et al., 1996; etc.). Some of these estimates have been mentioned in Table 4-2. The average natural recharge value of $10 \%$ of total annual precipitation has initially been assumed to represent the study area.

\subsection{Groundwater modeling}

Numerical groundwater models are used worldwide for various purposes such as testing hypotheses, predicting future behavior of aquifers, or organizing different hydrogeological data in a consistent conceptual framework (Anderson and Woessner, 2002). A model for predictive purposes especially requires good field data. However, a model with inadequate data can help guide data collection activities, particularly in those areas where detailed field data are critical to the success of the model (Wang and Anderson, 1982). In this research, a groundwater model has been developed that has the potential to replicate field-measured values. 
Table 4-2. Natural recharge estimates in hard rock aquifers by different methods.

\begin{tabular}{|c|c|c|c|c|}
\hline Rock type & Method & $\begin{array}{r}\text { Recharg } \\
(\% 0 \\
\text { rai }\end{array}$ & $\begin{array}{l}\text { estimate } \\
\text { total } \\
\text { all) }\end{array}$ & References \\
\hline \multirow{3}{*}{ Gabbro } & $\begin{array}{c}\text { Chloride mass } \\
\text { balance }\end{array}$ & & & \multirow{3}{*}{$\begin{array}{c}\text { Paralta and Oliviera, } \\
2005\end{array}$} \\
\hline & $\begin{array}{c}\text { Daily sequential } \\
\text { water balance } \\
\text { (BALSEQ model) }\end{array}$ & \multicolumn{2}{|c|}{$11 \%$} & \\
\hline & $\begin{array}{c}\text { Annual water } \\
\text { balance }\end{array}$ & \multicolumn{2}{|c|}{$14 \%$} & \\
\hline Granite & $\begin{array}{c}\text { Water balance } \\
\text { model }\end{array}$ & \multicolumn{2}{|c|}{$11.4 \%$} & Srinivas et al., 1999 \\
\hline Basalt & $\begin{array}{l}\text { Injected tritium } \\
\text { method }\end{array}$ & \multicolumn{2}{|c|}{$7.5 \%$} & \multirow{3}{*}{ Sukhija et al., 1996} \\
\hline Weathered-granite & $\begin{array}{l}\text { Environmental } \\
\text { tritium method }\end{array}$ & \multicolumn{2}{|c|}{$8 \%$} & \\
\hline Granite and gneisses & $\begin{array}{l}\text { Injected tritium } \\
\text { method }\end{array}$ & $7-8 \%$ & $\begin{array}{c}\text { Average } \\
7.5 \%\end{array}$ & \\
\hline $\begin{array}{c}\text { Granite and granitic } \\
\text { gneisses }\end{array}$ & $\begin{array}{l}\text { Injected tritium } \\
\text { method }\end{array}$ & $0.6-20 \%$ & $\begin{array}{c}\text { Average } \\
10.3 \%\end{array}$ & Chand et al., 2004 \\
\hline \multicolumn{2}{|c|}{ Mean natural recharge } & \multicolumn{3}{|l|}{$9.96 \%$} \\
\hline
\end{tabular}

\subsection{Conceptual model}

Before the construction of a groundwater model, a conceptual model should be developed, which is basically a pictorial representation of the groundwater flow system. 
conceptual model is especially helpful in simplifying the field problem and organizing associated field data. The accuracy of a numerical model depends on the degree of approximation of field situation in the conceptual model. It can be stated that errors in the conceptual model often lead to failure of numerical models to make accurate predictions.

\subsubsection{Hydrostratigraphic units}

Geologic units of similar hydrogeologic properties are termed hydrostratigraphic units. The study area has an unconfined aquifer system belonging to the Jharol sub-group of the Aravalli Super group of the Pre-Cambrian Eon. The stratigraphy was described in Chapter 3. The aquifers are mainly composed of schistose rocks with compositional variation and quartzitic rocks of varied thickness. Bedrock lithology and subsequent structural deformation of the bedrock control the hydraulic properties of the aquifer. Drilling records of three wells were obtained from the Groundwater Department of Rajasthan. One of the wells lies in the study area. Information for these wells is available to a depth of $50 \mathrm{~m}$. However, it was found that the maximum depth of wells in the study area was $20 \mathrm{~m}$, beyond which the rocks become hard and any subsequent digging requires use of explosives.

The key feature of an unconfined aquifer can be viewed as variable transmissivity with changing saturated thickness. Because the spatial variation of transmissivity in the area is not well known, it is assumed in the model that the saturated thickness of the aquifer does not change. Hence, for modeling purposes it is assumed for simplicity that the aquifer is confined and extends vertically with a uniform thickness of $20 \mathrm{~m}$. The effect of this assumption is expected to be minor. 


\subsubsection{Surface water bodies}

The rivers in the model domain are essentially storm channels which flow only during the monsoon season and dry up in the dry season. During the monsoon season, it was seen that the wells located in the vicinity of these streams had a remarkable increase in groundwater levels. This means that these streams contribute water to these wells. The stream network of the area is well connected to the aquifer. The other surface water bodies include four anicuts which are rainwater harvesting structures. It was observed that two of them dried up in the summer season and the other two had water through the summer season. However, to simplify the groundwater model, these individual anicuts and their spatial location were not explicitly considered in the model. However, the recharge from these artificial recharge structures has been indirectly accounted for in the estimation of net recharge during calibration of the model.

\subsubsection{Recharge zones}

Recharge takes place throughout the model domain. Rainfall is the principal source of recharge. However, the amount of recharge taking place can vary from place to place depending upon the amount of rainfall received and topography of the area. The flatter the topography is, the lesser the slope and the greater the standing time of water in these areas. Therefore, more water can percolate in these areas and contribute to recharge compared to highland areas and especially hills where steep slopes promote high runoff. Nevertheless, in a hard rock area the amount of recharge in an area will also significantly depend on the density of fractures, cleavages and joints. 
During the dry season, particularly during the winter season (rabi), recharge also takes place through irrigation return flow. Irrigation return flow refers to the water that is applied for irrigation but it is not taken up by the plants and, as a result,returns back into the aquifer. For modeling purposes, irrigation return flow is not explicitly considered because of the unavailability of data. As in the case of anicuts however, recharge arising from irrigation return flow is accounted for when net recharge is estimated during calibration of the model.

\subsubsection{Groundwater exploitation}

Open dug wells are the main source of water supply. There are some borewells in the area and some of these are quite deep $(400 \mathrm{~m})$. Their production is highly variable and presumably depends on the number of fractures encountered. They are thought not to be a large component of the water budget and have been not been explicitly considered in the modeling study. The volume of groundwater extracted for various purposes has been provided in Table 5.2 in chapter 5.

\subsubsection{Boundaries}

In the study area catchment, it was observed that the streams exit the catchment to the northwest. Since it is believed that groundwater flow patterns follow the surface water flow patterns, it can be inferred that groundwater also flows out of the model domain to the northwest. On the basis of this assumption, the north-western part of the catchment was assigned a constant head boundary (Figure 4-2). Apart from that, the entire 
catchment boundary was assigned a no-flow boundary assuming that the surface water divide coincides with the groundwater flow divide (Figure 4-2).

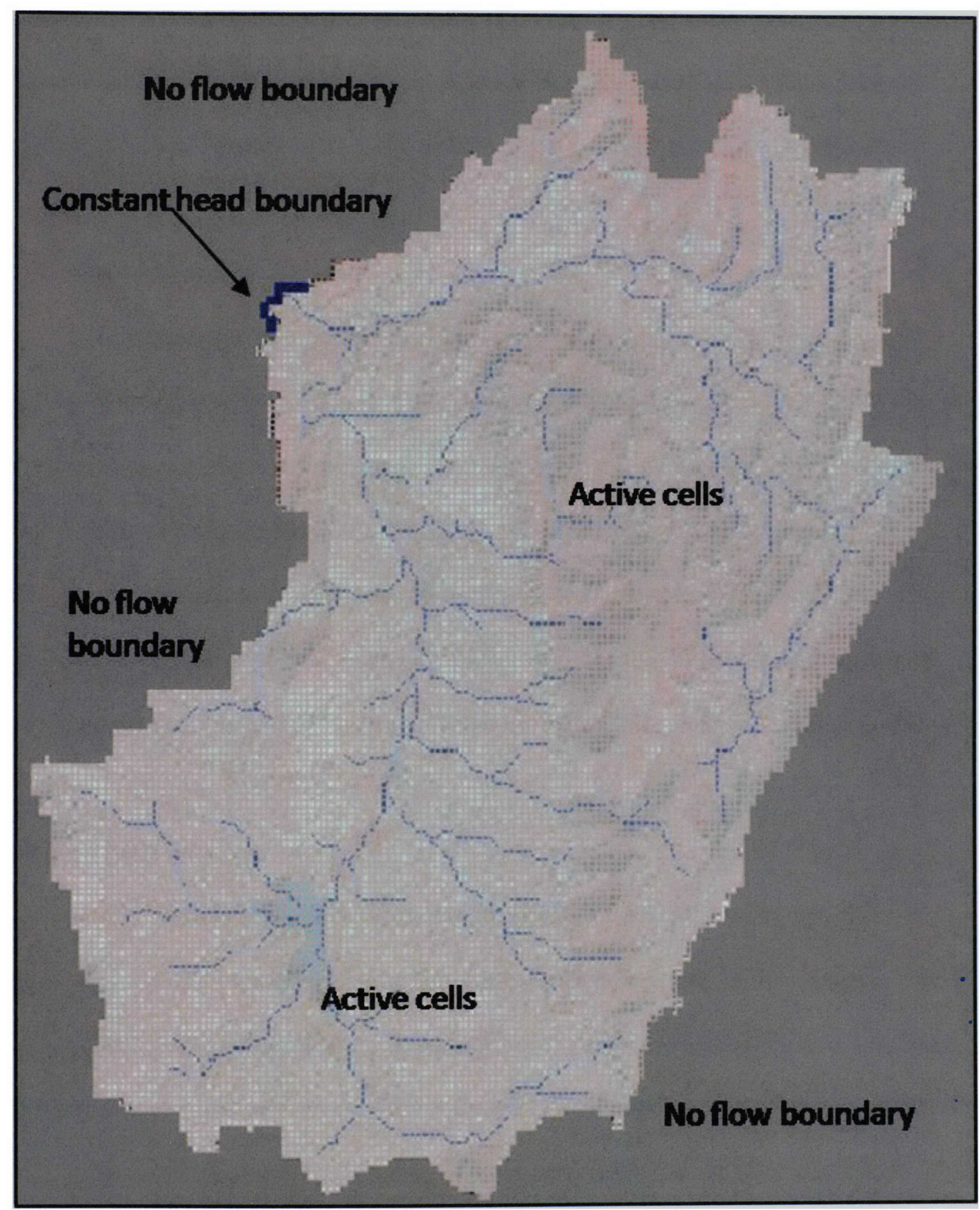

Figure 4-2. Model domain showing horizontal extent and boundaries. 


\subsection{Type of model}

Two-dimensional, distributed parameter, steady and transient confined aquifer models have been developed in this study. Keeping in mind the heterogeneity of the aquifer properties which play a key role in influencing groundwater flow in such hydrogeological systems, it is preferable to apply a distributed parameter model.

\subsection{Code selection}

In a groundwater modeling study, the development of a conceptual model is followed by translation of the physical system into mathematical equations known as governing equations and boundary conditions. These mathematical equations are solved numerically by an algorithm in a computer program. This computer program is commonly referred to as computer code. Based on the model objective of this study, a relevant computer code was selected which would be able to adequately represent hydrogeological processes, hydrostratigraphy, flow and boundary conditions, etc.

\subsubsection{Model code}

The model code selected for this study is MODFLOW, a modular threedimensional, block-centered, finite difference code developed by the United States Geological Survey (USGS) for layered aquifer systems, (Harbaugh and McDonald, 1996). The groundwater flow model MODFLOW numerically approximates the solution of the partial differential equation, derived by combining an equation of continuity and Darcy's law, for three-dimensional groundwater flow through porous media. This partial differential equation (Equation 4-1), which is the governing equation representing the 
groundwater flow system in the study area based on certain boundary conditions, has to be solved to get the spatial distribution of heads. The general partial differential equation to be solved for transient conditions can be written as:

$K_{x} \frac{\partial^{2} h}{\partial x^{2}}+K_{y} \frac{\partial^{2} h}{\partial y^{2}}+K_{z} \frac{\partial^{2} h}{\partial z^{2}}=S_{S} \frac{\partial h}{\partial t}-R \quad$ (Anderson and Woessner, 2002)

Where:

$\begin{array}{lll}K x, K y, K z & : & \text { Hydraulic conductivity along } \mathrm{x}, \mathrm{y}, \mathrm{z} \text { co-ordinate axes } \\ h & : & \text { Potentiometric head } \\ S s & : & \text { Specific storage } \\ R & : & \text { Volumetric flux of sources and sinks per unit volume } \\ t & : & \text { Time }\end{array}$

For steady-state conditions the term $S_{s} \frac{\partial h}{\partial t}$ becomes zero and equation 4-1 becomes

$$
K_{x} \frac{\partial^{2} h}{\partial x^{2}}+K_{y} \frac{\partial^{2} h}{\partial y^{2}}+K_{z} \frac{\partial^{2} h}{\partial z^{2}}+R=0
$$

The application of equations 4-1 and 4-2 are valid under the following conditions:

1. The aquifer is saturated

2. Darcy's law is valid

3. Mass is conserved

The equations for boundary conditions can be given as:

For no-flow boundaries, the head gradient perpendicular to a boundary is set to zero and can be represented mathematically as:

$$
\frac{\partial h}{\partial x}=0
$$

and, $\quad \frac{\partial h}{\partial y}=0$ 
For constant head boundaries:

$h=c$, where $c$ is constant

\subsubsection{Rationale for selecting MODFLOW}

The groundwater flow model MODFLOW is well-documented as well as easy to understand (McDonald and Harbaugh, 1988) and is very popular and widely accepted within the modeling community. It is available through the public domain and the availability of a number of third party pre- and post-processors make the model easier to use. Groundwater flow in complex hydraulic conditions with various natural hydrological processes can be simulated under steady- and transient-state conditions in an irregularly shaped flow system in which the aquifers can be either confined, unconfined, or both confined and unconfined. Multi-aquifer and large areal extent modeling can also be done using MODFLOW. Additionally, MODFLOW is capable of simulating the effects of wells, recharge, rivers, drains, evapotranspiration and head dependent boundaries. Furthermore, anisotropic and spatially varying hydraulic conductivities and transmissivites can be assigned to different layers and the storage coefficient can be heterogeneous.

\subsection{Processor}

For loading information into the model and observing model results, Processing MODFLOW for Windows (PMWIN) version 5.3.0 (Chiang and Kinzelbach, 2003) was used as a pre- and post-processor for MODFLOW. PMWIN is a well-documented and widely-used complete simulation system, which is equipped with supported modeling 
packages like a block-centered flow package, a recharge package, well package, etc., and other useful modeling tools such as a presentation tool, result extractor, water budget calculator, graph viewer, etc. It is capable of handling up to and including 1000 stress periods, 80 layers, and 250,000 cells for each model layer (Chiang and Kinzelbach, 2003).

\subsection{Model Set-up}

\subsubsection{Model Domain}

\subsubsection{Horizontal extent}

A small catchment located in the southern part of the Wakal River basin was selected as the domain for groundwater modeling. The horizontal extent of the model domain is shown in Figure 4.3. The approximate areal extent of the model domain is 118 $\mathrm{Km}^{2}$. Maximum length and width of the catchment are roughly $15 \mathrm{Km}$ and $10 \mathrm{Km}$, respectively. The model domain lies within 330395 - 343327 Easting and $2676345-$ 2692351 Northing.

\subsubsection{Vertical extent}

The model of the study area was constructed with one layer representing a confined aquifer. As described in the conceptual model, the vertical extent of the model has been assumed to be of $20 \mathrm{~m}$ uniform thickness. 


\subsubsection{Discretization}

In a numerical groundwater model, the modeling domain is replaced by a discretized domain which consists of an array of nodes and related finite difference blocks (also referred to as cells) (Anderson and Woessner, 2002). The locations of these cells are represented by columns, rows and layers. Hydraulic head is calculated at each of these cells. The model domain was discretized into 143 columns and 177 rows using 90.4 $\times 90.4 \mathrm{~m}$ grid spacing corresponding to that of the Shuttle Radar Topography Mission (SRTM) digital elevation model (DEM), which was intended to be used to assign elevations for the top and bottom of the aquifer, resulting in 25,311 grid cells. Ultimately the elevations were irrelevant to the two-dimensional confined aquifer model. These cells were defined to be active, inactive, and constant head cells by assigning values of 1,0 and -1 respectively using the IBOUND array in MODFLOW. Cells outside the no-flow boundary were defined as inactive cells, cells in the constant head boundary were defined as constant head cells, and the remaining cells in the modeling domain where heads will be calculated were defined as active cells. The total number of active grid cell in the model domain is 13,616 .

\subsubsection{Model boundaries}

Boundary conditions must be defined in order to constrain the problem and achieve unique solutions for the partial differential equations (Wang and Anderson, 1982). Dependent variables (head) or derivatives of dependent variables (flux) are specified at the boundaries of the model domain by mathematical statements known as 
boundary conditions (Anderson and Woessner, 2002). Generally, boundaries can be of three types:

1) Specified head boundary or Dirichlet conditions where heads for surfaces bordering the flow region are known.

2) Specified flux boundary or Neumann conditions where flows across the surfaces bordering the flow region are known.

3) Head dependent flow boundary or Cauchy conditions where flows across the surfaces bordering the flow region are calculated provided boundary head value are known.

Based on physical features and the hydraulic conditions as described in the conceptual model, applicable boundary conditions were defined.

\subsubsection{Lateral model boundaries}

Model boundary conditions are shown in Figure 4.3. No-flow boundaries were assigned along the catchment boundary as discussed in the conceptual model except in the north-western part where it is assumed that groundwater is flowing out of the aquifer system and is, therefore, assigned a constant head boundary below the lowest land surface elevation in the domain.

\subsubsection{Model layer thickness}

The aquifer was assigned a thickness of $20 \mathrm{~m}$. 


\subsubsection{Initial hydraulic head}

Initial hydraulic heads are required by MODFLOW at the beginning of a flow simulation (Chiang and Kinzelbach, 2003). For steady-state models, the fixed head cell values should be the actual values and the active cells can be arbitrary values. Due to a lack of field measured data at the constant head boundary, the constant head cells were assigned a value of $488 \mathrm{~m}$, which is below the lowest elevation of the land surface in the constant head boundary area.

For the transient model, however, actual values of initial hydraulic heads must be provided (Chiang and Kinzelbach, 2003). Therefore, heads obtained from fully calibrated steady-state model were used as initial hydraulic heads for the transient model.

\subsubsection{Hydraulic parameters}

The primary hydraulic parameter required by a steady-state model is either hydraulic conductivity or transmissivity. Pumping tests were carried out at Shyampurakala and Amor in the study area and then pumping test data were analyzed by Jacob's straight line method. The transmissivity values were calculated to be $38.15 \mathrm{~m}^{2} / \mathrm{d}$ and $15.12 \mathrm{~m}^{2} / \mathrm{d}$ respectively (see section 5.3 ). Because the potential variation of transmissivity in natural systems can range over many orders of magnitude and the calculated and literature-derived (Table 5-3) transmissivities from the region vary by only two orders of magnitude, the transmissivity is considered relatively well constrained. Based on the Shyampurkala aquifer test, a transmissivity of $38.15 \mathrm{~m}^{2} /$ day was applied as an initial value for the steady-state model.

For the transient-state model, the calibrated values of transmissivity from the steady-state model were applied. The calibrated values are discussed in the following 
chapter. Another important parameter required for transient-state model is the specific storage or storage coefficient values. Storage coefficient values were obtained from the literature. Storage coeffient values calculated in similar hard rock terrain range from $0.00039-0.09$. Storage coefficient values determined by the Groundwater Department of Rajasthan (GOR, 1979) by pumping tests using various analysis techniques in similar hard rock terrain in the Aravalli Mountains are listed in Table 4-3.

Table 4-3. Storage coefficient estimates for different rock types in Aravalli Mountains. Source: Government of Rajasthan, 1979.

\begin{tabular}{|c|c|c|c|c|}
\hline Rock type & $\begin{array}{l}\text { Dr. Kamal } \\
\text { F. Saad } \\
\text { method }\end{array}$ & $\begin{array}{l}\text { Theis } \\
\text { method }\end{array}$ & $\begin{array}{l}\text { Chow's } \\
\text { method }\end{array}$ & $\begin{array}{l}\text { Cooper and } \\
\text { Jacob's } \\
\text { method }\end{array}$ \\
\hline \multirow{5}{*}{$\begin{array}{l}\text { Marwar } \\
\text { phyllite }\end{array}$} & 0.0245 & \multirow{5}{*}{0.000618} & \multirow{5}{*}{0.017} & \multirow{5}{*}{0.0134} \\
\hline & 0.0256 & & & \\
\hline & 0.0227 & & & \\
\hline & 0.048 & & & \\
\hline & 0.0941 & & & \\
\hline \multirow{7}{*}{ Kharchi } & 0.0028 & \multirow{7}{*}{0.00057} & \multirow{7}{*}{0.00117} & \multirow{7}{*}{0.00039} \\
\hline & 0.0034 & & & \\
\hline & 0.0024 & & & \\
\hline & & & & \\
\hline & & & & \\
\hline & 0.00699 & & & \\
\hline & 0.0067 & & & \\
\hline
\end{tabular}


The transient-state model was calibrated by applying 0.00039 as a starting guess for the storage coefficient. The calibrated values are discussed in the following chapter.

\subsubsection{Recharge}

As previously discussed, rainfall is the main source for recharge of groundwater. From a literature review, the recharge value has been estimated to be approximately $10 \%$ of the annual precipitation in hard rock areas. Thus, an initial recharge value of 0.0984 m/year was applied for steady-state model.

Recharge for transient state is discussed in the following chapter.

\subsubsection{Boreholes and observation wells}

Water level measurements were recorded for the pre-monsoon and during monsoon periods for 187 wells in the study area. Out of 187 wells, 168 wells were used for steady-state calibration of the model. The remaining 19 wells were used to validate the model and then later were used to calibrate the transient-state model.

\subsubsection{Groundwater exploitation}

The well package of MODFLOW was used to define withdrawal from the production wells. This module assigned abstraction of groundwater to the model as negative recharge values. MODFLOW assumes that the wells are fully penetrating the aquifer. Abstraction was calculated for each well and applied to the model.

For the steady-state model, abstraction for the year 2006 as a whole had to be applied for each well separately in the model. The total abstraction for the year 2006 was 
calculated to be approximately $2,100,000 \mathrm{~m}^{3} /$ year. However, for the transient state model, different abstraction rates were applied during different stress periods.

\subsubsection{Evapotranspiration}

Although, evapotranspiration plays an important role in groundwater studies, evapotranspiration was not considered as a separate component of the model. This is because evapotranspiration has already been considered during calculation of net recharge.

\subsection{Methodology for the delineation of potential recharge sites}

To delineate potential recharge zones in the study area catchment in the Wakal River basin, different thematic maps were prepared from satellite imagery and existing maps. The methodology used for this study has been illustrated in Figure 4-3.

Thematic maps of land cover and normalized difference vegetation index (NDVI) were generated from Landsat $7($ ETM+) imagery. The maps of slope, drainage and catchments were generated using the digital elevation model (DEM) acquired from Shuttle Radar Topographic Mission. Geological information (lithology, structure, lineations and joints) were extracted from existing maps of 1:10000 scale. Field data included groundwater level data which were collected for duration of three months in 2006. 


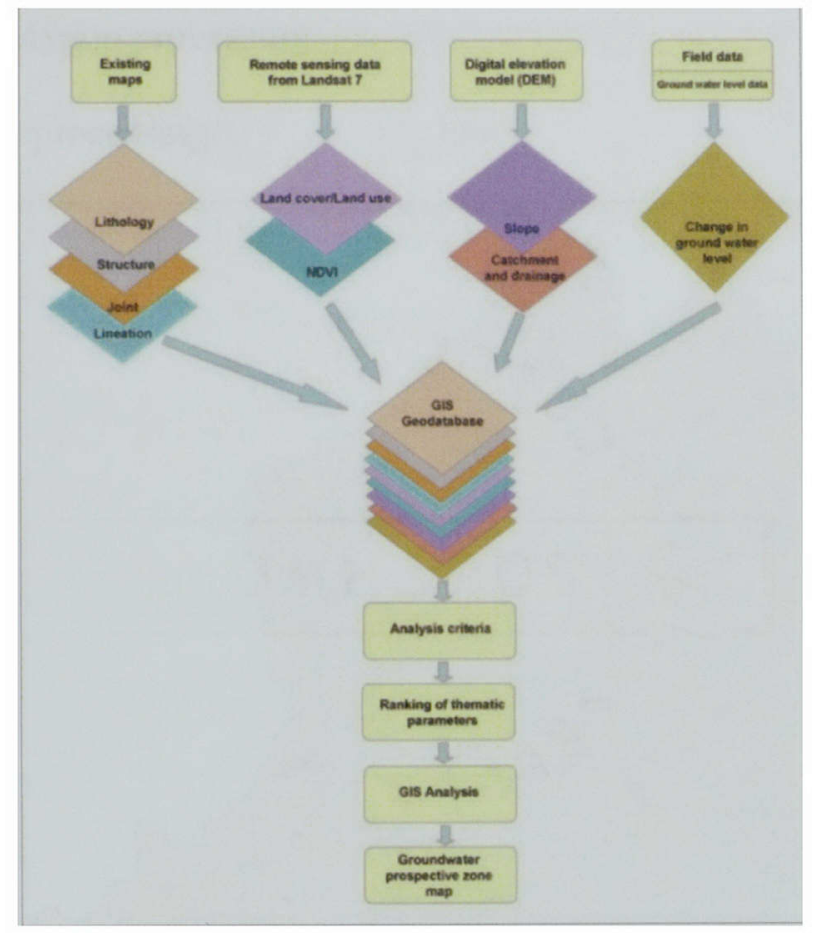

Figure 4-3. Flow chart showing the methodology for the delineation of recharge sites.

\subsubsection{Drainage and catchments}

Terrain preprocessing was performed with ArcHydro extension (Maidment, 2002) in ArcMap 9.2 (ESRI, 2006) using digital elevation model to delineate the catchments and drainage line (Figure 4-4). The steps involved were:

- Fill sinks

- Flow direction

- Flow accumulation

- Stream definition

- Stream segmentation

- Catchment grid delineation 
- Catchment polygon processing

- Drainage line processing

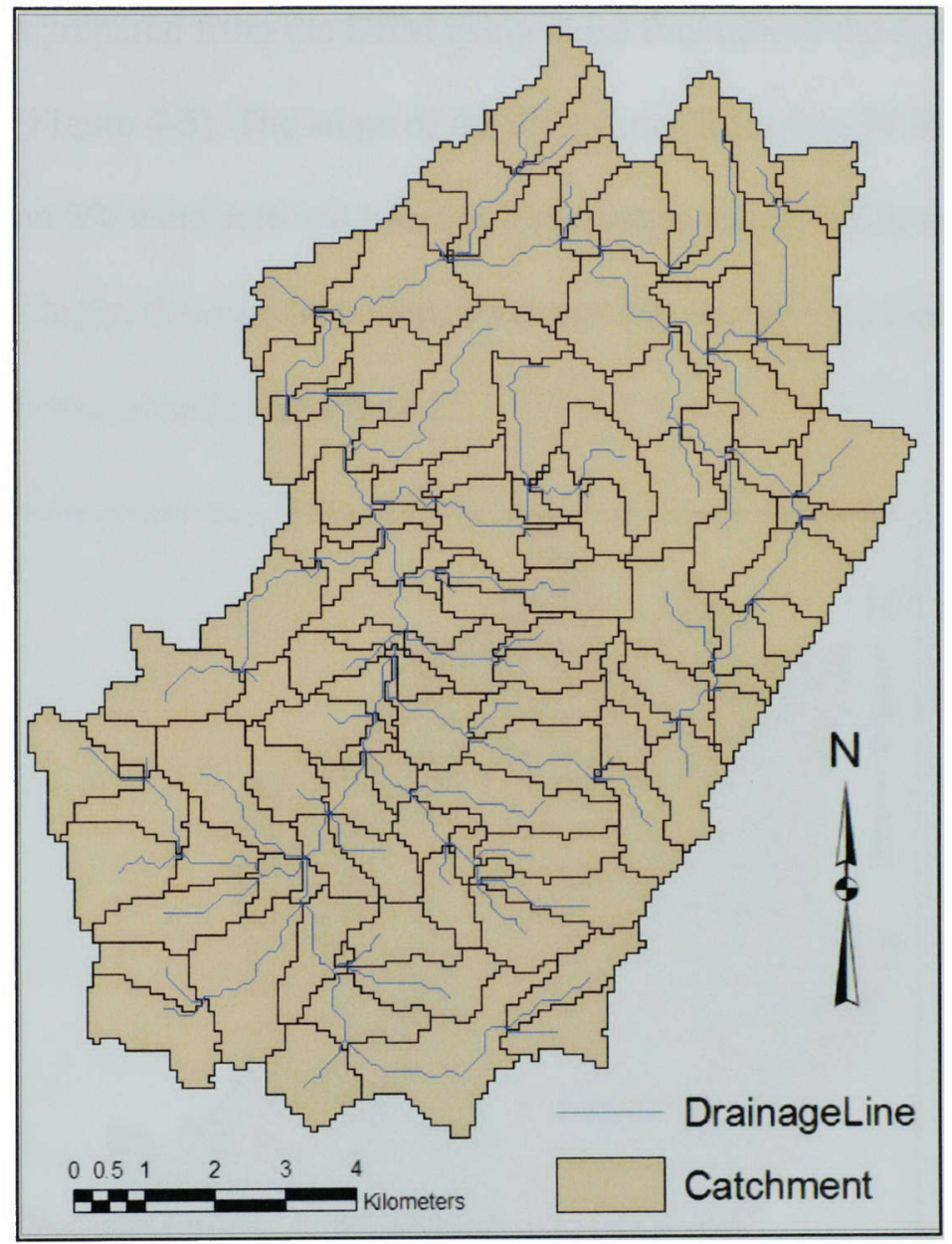

Figure 4-4. Map showing catchment and drainage lines.

\subsubsection{Slope}

Slope is maximum rate of change of altitude. For artificial recharge studies, it is very important to know the slope of the area:

- To get a better perception of the landforms (Saraf et al., 2004) 
- Aquifer replenishment is favorable in the areas of lesser slope which usually have high infiltration (Anbazhagan et al., 2005)

A slope map was prepared from the DEM using slope function of the spatial analyst tool of ArcMap 9.2 (Figure 4-5). The slope of the area varies from 0 to $77.99 \%$. Areas with slope of less than $5 \%$ were selected because lesser slope aids in infiltration and runoff is less. Accordingly, the area with slope less than 5\% was given a rank of 1 and slope higher than $5 \%$ was awarded a rank of 2 .

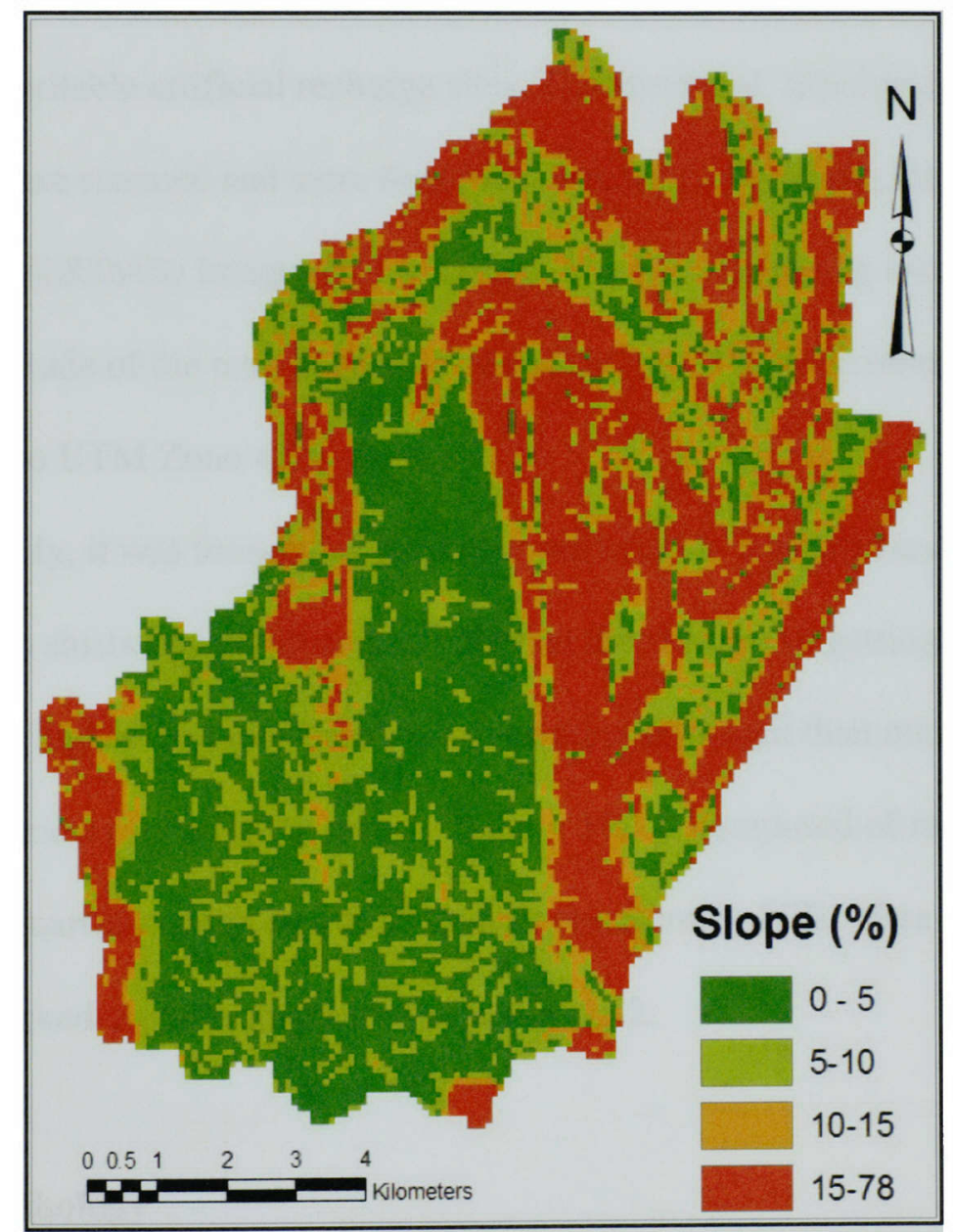

Figure 4-5. Slope map of the study area. 


\subsubsection{Geology}

The study area consists of mainly three types of rock namely mica schist, phyllite, and quartzite. All these rock types are metamorphic and are hard and compact. These hard rocks usually lack primary porosity and movement and percolation of water takes place through secondary porosity which is formed during deformation and weathering of rocks in the form of cleavages, fractures, lineations, and joints. It is important to map these features (cleavages, joints, lineations, and fractures) because water can percolate through them and can travel up to several kilometers and hence, play a major role in identification of suitable artificial recharge sites. The structural, lithological, lineation, and joint maps were scanned and were then georeferenced using Earth Resources Data Analysis System (ERDAS) Imagine 9.1 software. The georeferencing was done using the latitude and longitude of the map as ground control points. The georeferenced image was then reprojected to UTM Zone $43 \mathrm{~N}$.

In this study, it was found that quartzites were highly fractured and jointed compared to mica shists and phyllites meaning that the chances of getting water in quartzite is much higher. But quartzite was given a lower weight than mica schist and phyllite because most of the flatter terrain (slope $<5 \%$ ) is composed of mica schist and phyllite and the quartzites exist on a high topography forming hills. Mica schists and phyllites were ranked 1 while quartzite was ranked as 2 .

\subsubsection{Geomorphology}

Geomorphology can be described as the study of landforms (Rao, 2006).

Landforms are important because they are the good surficial indicators in the search for 
suitable artificial recharge sites. This is so because each landform differs in its physiographic disposition, areal extent etc. (Krishnamurthy et al., 2000). It was initially proposed in the project to find the types of landforms present in the study area using satellite imagery, but due to the limited scope of this study, it was not possible to delineate the geomorphological features.

However, the major landforms in the study area were identified from the existing maps which are valley fills and pediplains. They were, however, not ranked.

\subsubsection{Land cover / Land use}

Land cover/use information is important for this study because the extent of groundwater requirement and utilization can be identified (Krishnamurthy et al., 2000). In addition, infiltration, erosion and evapo-transpiration are characteristics of the runoff process which vary from one land cover to another (Anbazhagan et al., 2005). Remote sensing has the capability for synoptic viewing and multi-spectral and multi-temporal coverage and due to this fact; remote sensing has been successfully used in classifying land cover in many such studies (Krishnamurthy et al., 2000). The land cover has been classified as forest, agriculture and water in this study.

To classify the landcover, those areas were selected where the slope were less than $15 \%$. This was necessary because of two reasons:

1. Areas having high slope are not ideal for artificial recharge because most of the rainfall in these areas will end up being runoff due to steep slope.

2. The satellite image has shadows of hills which lie in areas with high slope and could be misclassified as water. 
respective land cover under consideration existed. This was necessary to classify the land cover as accurately as possible. After classification, the swipe tool was used to verify the classification visually. Accuracy assessment of the classified image could not be performed due to the absence of suitable ground truth data. A map of land cover/land use is shown in Figure 4-6.

Higher rank (1) was assigned to forest land cover class because forests have more potential to retain water and aid in the infiltration process. A rank of 2 was assigned to agricultural areas.

\subsubsection{Normalized Difference Vegetation Index (NDVI)}

The relative abundance and activity of green vegetation is indicated by radiometric measures and dimensionless vegetation indices like NDVI (Jensen, 2005). NDVI is calculated as:

$\mathrm{NDVI}=\left(\rho_{\text {nir }}-\rho_{\text {red }}\right) /\left(\rho_{\text {nir }}+\rho_{\text {red }}\right)$

Where, $\rho_{\text {nir }}$ is the near-infrared radiant flux, and

$\rho_{\text {red }}$ is the red reflected radiant flux

A map of NDVI is shown in Figure 4-7. NDVI values usually have a range from +1 to -1 . NDVI with +1 value means very healthy and good vegetated areas whereas a NDVI value of -1 corresponds to water.

It is necessary to identify well-vegetated areas because these areas usually have increased infiltration and reduced runoff components (Anbazhagan et al., 2005). It has 
been established that there is a gradual increase in the runoff yield from forest cover, grassland, farmland, barren land and urban areas (Anbazhagan et al., 2005).

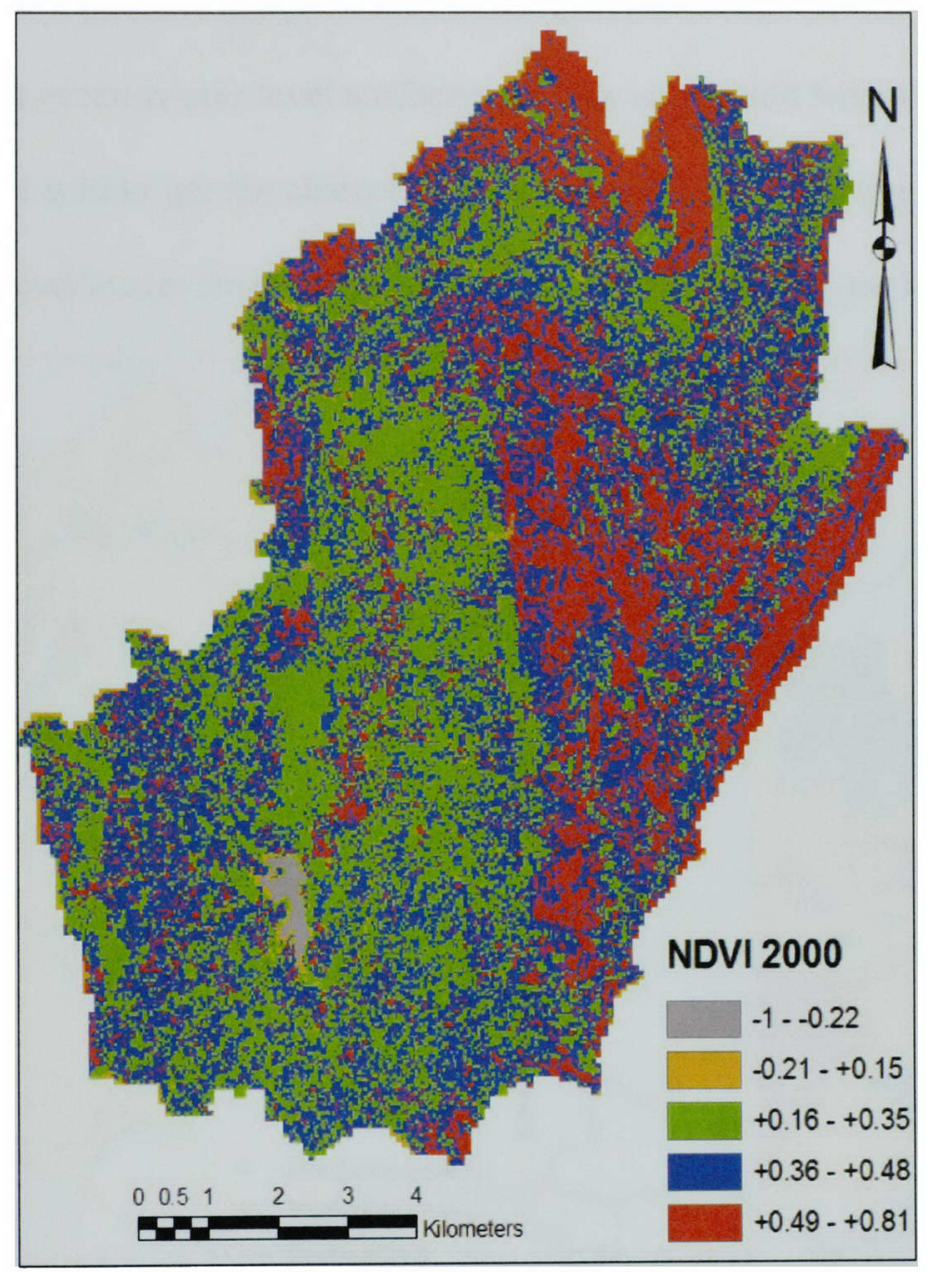

Figure 4-7. Map of NDVI in the study area.

In this study, areas with NDVI higher than 0.5 were selected and assigned a rank of 1 whereas areas with lower NDVI values were assigned a rank of 2.

\subsubsection{Groundwater level data}

Pre-monsoon and post-monsoon groundwater levels were collected from open dug wells in the study area during the months of late May to early August in 2006 and 
were used to create a groundwater level surface for the pre-monsoon and post-moonsoon period using kriging. Figure 4-8 (a) shows the location of open dug wells. The wells were divided into zones 1 and 2 to reduce errors in the generation of water level surface maps. The pre-monsoon groundwater level surface was then subtracted from the post-monsoon groundwater level grid to get the change in groundwater level using the raster calculator. The change in groundwater level for the two zones is shown in Figure 4-8 (b).

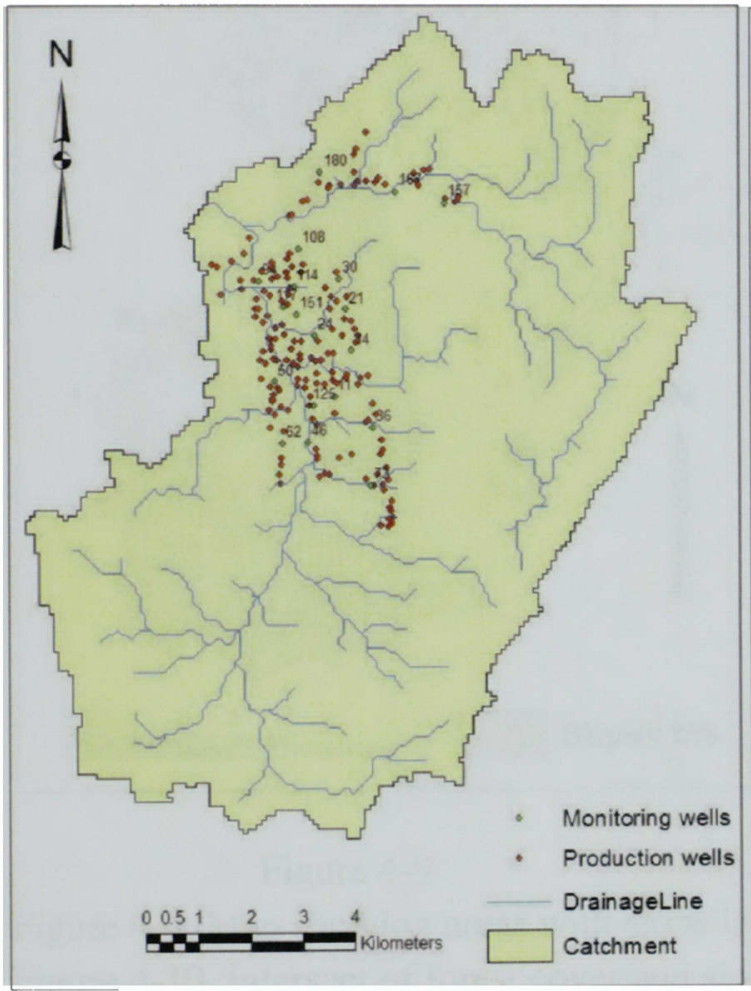

(a)

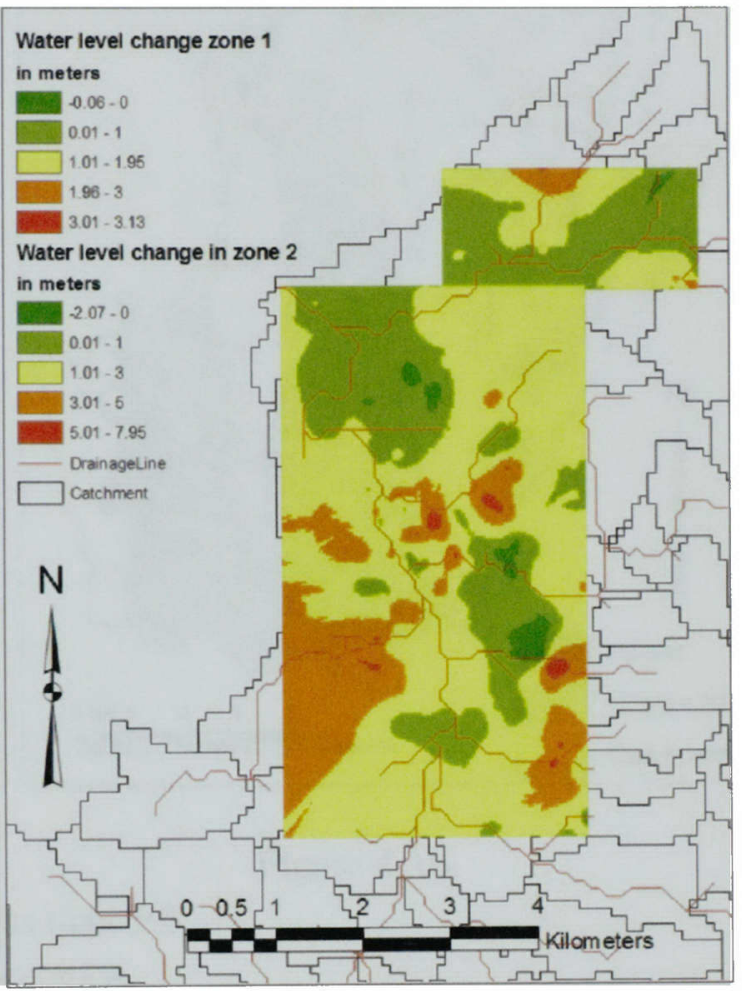

(b)

Figure 4-8 (a). Map showing the location of open dug wells.

Figure 4-8 (b). Map showing changes in groundwater level.

After assembling all the parameters for this study, areas with slope less than 5\%

were selected using the raster calculator. It was necessary because areas with lower slope will have more infiltration and less runoff. The grid generated from this step was converted to a polygon shapefile using the conversion tool (Figure 4-9). 
In the next step, areas under forest were selected from the land cover grid and were converted into a shapefile. The forests included all those areas with good tree cover which also included areas with trees in the agricultural areas. Next, the forest shapefile was selected that were within areas having slope of less than 5\% (Figure 4-10).

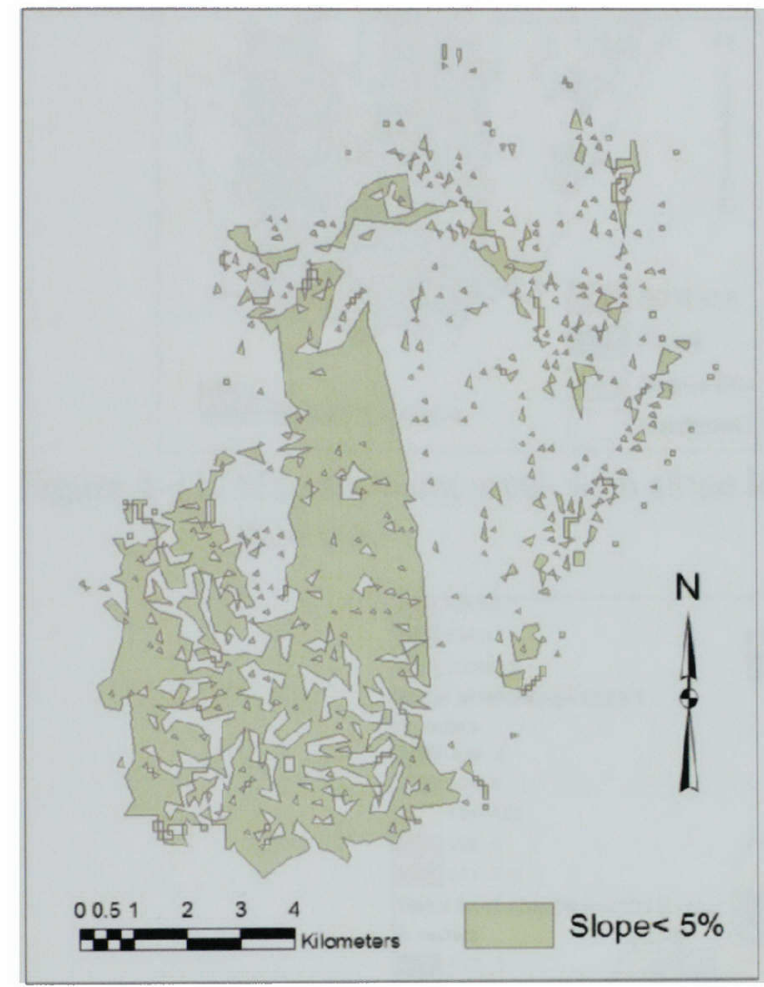

Figure 4-9.

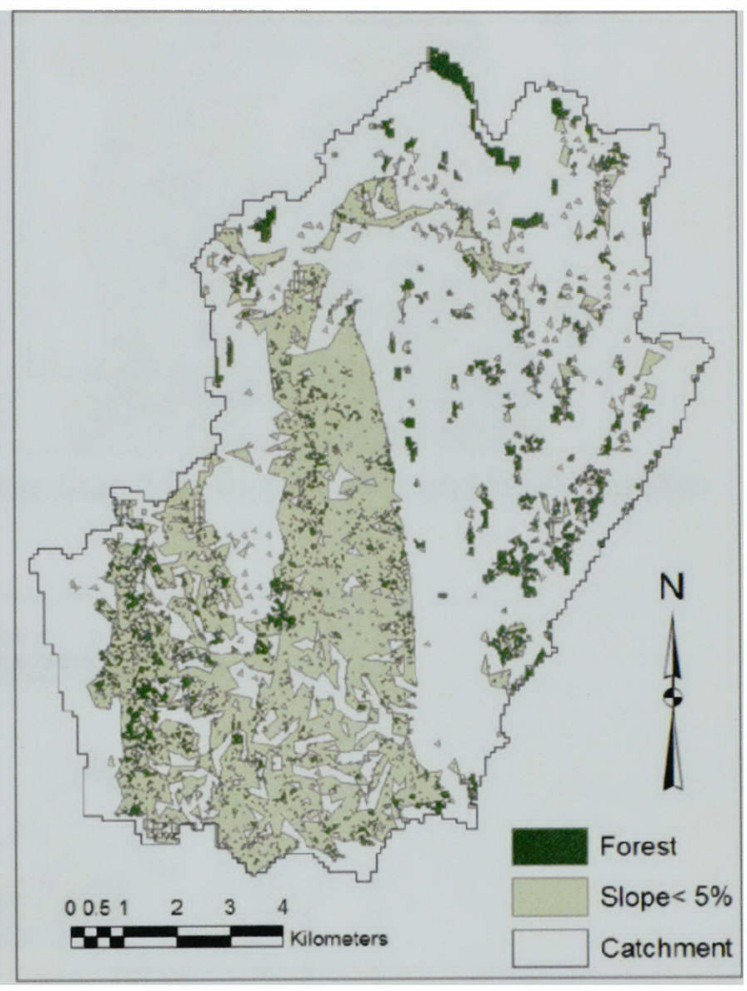

Figure 4-10.

Figure 4-9. Map showing areas with slope less than 5\%.

Figure 4-10. Intersect of forest cover and slope $<5 \%$.

Next, areas having NDVI values of more than 0.5 were selected. A shapefile of this area was also created and then selected using "select by location" and using the function "that lie completely within" the shapefile having forest cover in areas with slope of less than 5\% (Figure 4-11).

In the next step, the change in groundwater level grid was superimposed on the shapefile created in the previous step (Figure 4-12). 


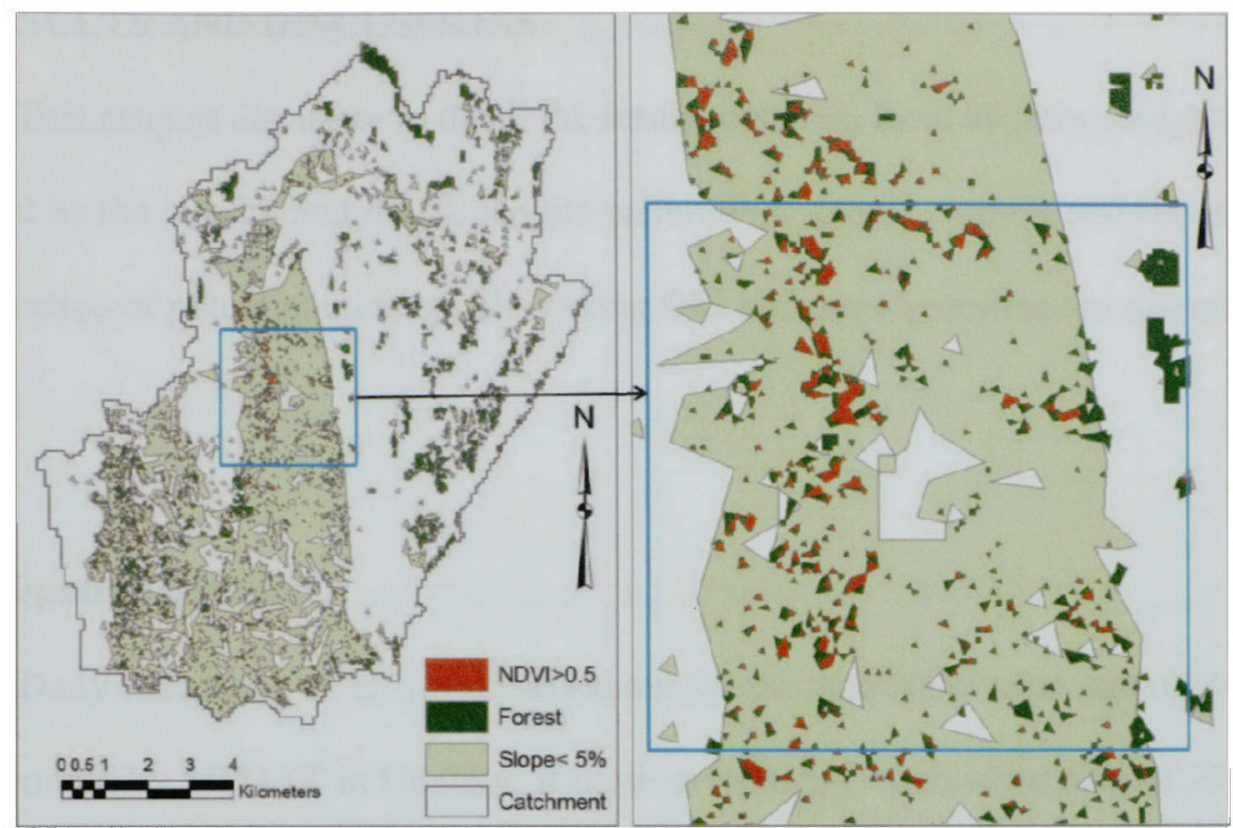

Figure 4-11. Map showing areas with slope less than 5\%, forest cover and NDVI greater than 0.5 .

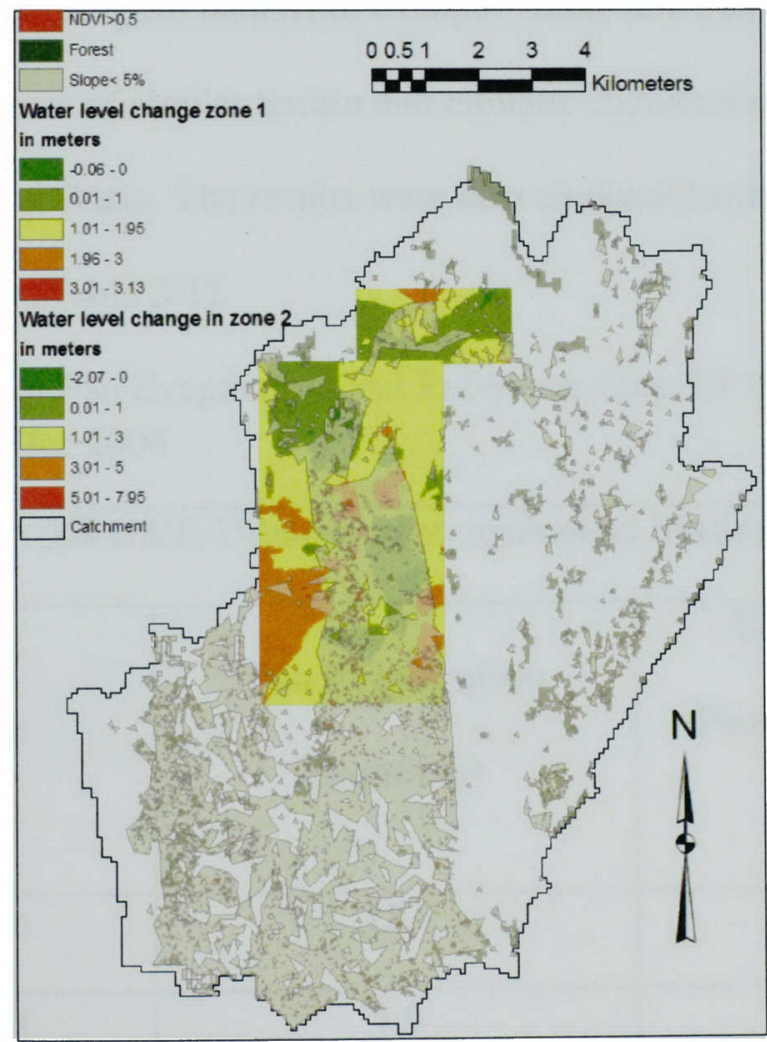

Figure 4-12. Map showing areas with slope less than 5\%, forest cover, high NDVI and groundwater level. 


\subsection{RESULTS AND DISCUSSIONS}

This chapter discusses in detail the results obtained from the data analysis followed by the steady- and transient-state calibration, model outputs, and forecasts. The identification of potential recharge sites using GIS and remote sensing are discussed at the end.

\subsection{Evapotranspiration}

Daily estimation of $\mathrm{ET}_{\mathrm{o}}$ was carried out for the year 2006 using meteorological data recorded by MPUAT in Udaipur, Rajasthan (Singh, Unpublished data, 2006). This was necessary because there is no available data for Wakal Basin as such and results from analysis of meteorological data from Udaipur could be taken as representative $\mathrm{ET}_{\mathrm{o}}$ for Wakal Basin because of similar terrain and climatic characteristics and close proximity to the Wakal Basin. The results were also compared with pan evaporation data from the same station (Table 5-1).

Table. 5-1. Statistics of Pan Evaporation and Reference Crop ET (Modified PenmanMonteith) for 2006

\begin{tabular}{|c|c|c|}
\hline \multicolumn{2}{|c|}{ MPUAT, Udaipur Meteorological Station } \\
\hline \multirow{2}{*}{ Statistics } & $\begin{array}{c}\text { Pan Evaporation } \\
\text { (mm/day) }\end{array}$ & $\begin{array}{c}\text { ET }_{\mathbf{o}} \text { (Modified } \\
\text { Penman-Monteith) } \\
\text { (mm/day) }\end{array}$ \\
\hline Maximum & 15.3 & 8.9 \\
\hline Minimum & 1.6 & 1.7 \\
\hline Average & 5.1 & 4.1 \\
\hline
\end{tabular}


Daily pan evaporation and daily $\mathrm{ET}_{0}$ estimated by modified Penman-Monteith method show similar variation throughout the year, but pan evaporation values were higher compared to $\mathrm{ET}_{\mathrm{o}}$ (Figure 5-1). $\mathrm{ET}_{\mathrm{o}}$ peak during the summer season when temperature and wind speed increase and then $\mathrm{ET}_{\mathrm{o}}$ decrease gradually with the onset of monsoon season (Figure 5-2). Mean daily $\mathrm{ET}_{\mathrm{o}}$ for the Wakal River basin was calculated to be $4.1 \mathrm{~mm} / \mathrm{day}$.

Although, $\mathrm{ET}_{\mathrm{o}}$ has been calculated from a variety of climatic and physiographic data recorded by MPUAT in Udaipur, Rajasthan, errors associated with the data are not known. Since correction factors for these data have not been taken into account, the results might be an under-estimate or over estimate of $\mathrm{ET}_{\mathrm{o}}$. The spatial distribution of $\mathrm{ET}_{\mathrm{o}}$ could not be studied due to lack of data from different meteorological stations in the study area.

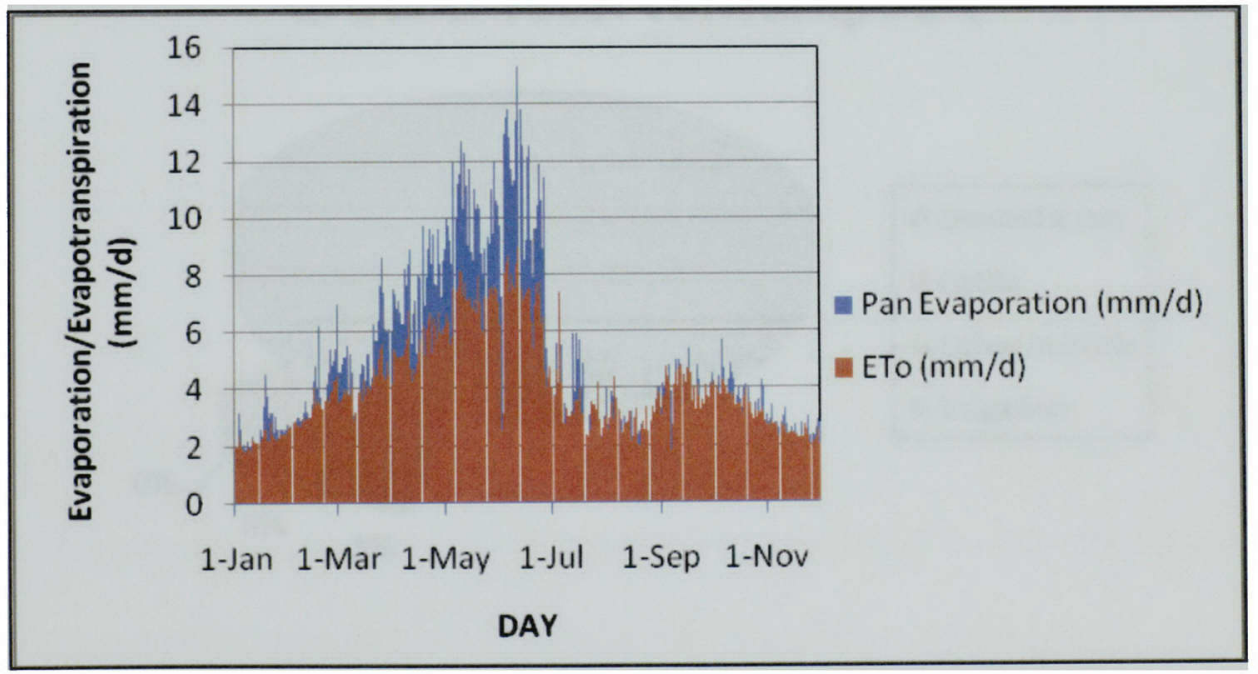

Figure 5-1. Daily variations of Pan Evaporation and Reference Crop ET $\left(\mathrm{ET}_{0}\right)$ in 2006 


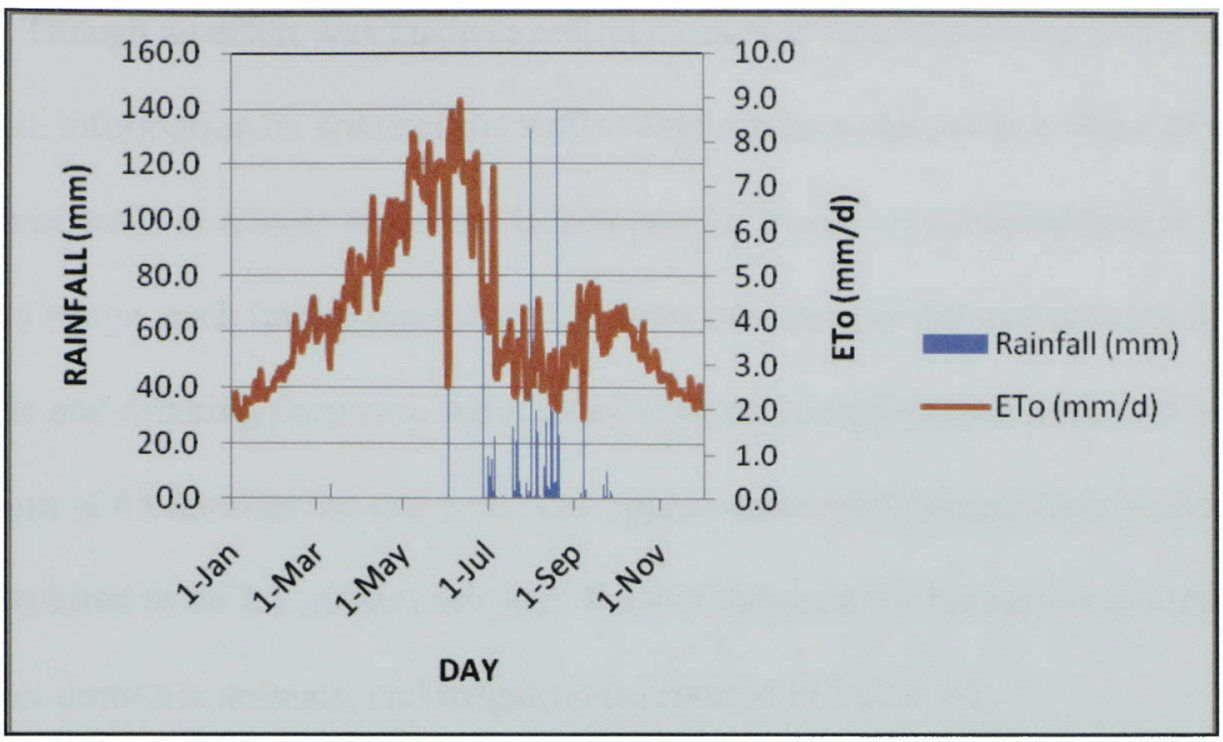

Figure 5-2. Temporal variation of rainfall and evapotranspiration in 2006.

\subsection{Groundwater extraction}

The consumption pattern is shown in Figure 5-3. More than 90\% of groundwater is used for irrigation purposes.

\section{Groundwater consumption}

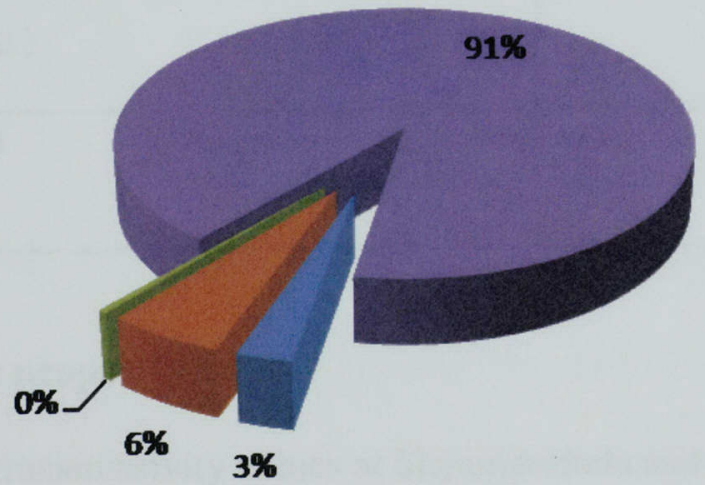

\begin{tabular}{|l|}
\hline - Domestic use \\
- Cattle \\
= Other animals \\
= Irrigation
\end{tabular}

Figure 5-3. Groundwater consumption by various sectors in the study area. 
Though an effort was made to collect extraction information on all the wells surveyed, information on some of the wells could not be collected as a result of the location of wells in remote areas that lacked people. Based on collected data, it was found that on average, each family consumes 103 liters of water per day collectively for domestic and drinking purposes. Also, an average of 11 families use each well with a maximum of 65 families for one well. The approximate total groundwater withdrawal was calculated to be 2.1 million $\mathrm{m}^{3} /$ year. Total withdrawal for human consumption, cattle and other domestic animals, and irrigation is reported in Table 5-2.

Table 5-2. Groundwater consumption in the study area.

\begin{tabular}{|l|c|}
\hline \multicolumn{1}{|c|}{ Category } & Consumption (m³/year) \\
\hline Drinking and domestic water use & 55883 \\
\hline Cattle & 115190 \\
\hline Other domestic animals (e.g. goat, & 9460 \\
sheep, etc.) & 1895181 \\
\hline Irrigation & \\
\hline
\end{tabular}

\subsection{Aquifer properties}

The transmissivity values at Shyampurkala and Amor were calculated by analysis of drawdown versus time data by Cooper-Jacob straight line method and was estimated to be $38 \mathrm{~m}^{2} / \mathrm{d}$ and $15 \mathrm{~m}^{2} / \mathrm{d}$ respectively. These values were compared with transmissivity values obtained by the Groundwater Department which they derived for similar phyllitic 
terrain using pumping tests in the Aravalli Mountains. The transmissivity values obtained by various methods are listed in Table $5-3$.

Table 5-3. Transmissivity for different rock types (Source: GOR, 1979)

\begin{tabular}{|c|c|c|c|c|c|c|}
\hline Rock type & $\begin{array}{c}\text { Dr. Stevenson } \\
\text { method } \\
\left(\mathrm{m}^{2} / \text { day }\right)\end{array}$ & $\begin{array}{c}\text { Dr. Kamal } \\
\text { F. Saad } \\
\text { method } \\
\left(\mathrm{m}^{2} / \text { day }\right)\end{array}$ & $\begin{array}{c}\text { Theis } \\
\text { method } \\
\left(\mathrm{m}^{2} / \text { day }\right)\end{array}$ & $\begin{array}{c}\text { Theis } \\
\text { recovery } \\
\text { method } \\
\left(\mathrm{m}^{2} / \text { day }\right)\end{array}$ & $\begin{array}{c}\text { Chow's } \\
\text { method } \\
\left(\mathrm{m}^{2} / \text { day }\right)\end{array}$ & $\begin{array}{c}\text { Cooper } \\
\text { and } \\
\text { Jacob's } \\
\text { method } \\
\left(\mathrm{m}^{2} / \text { day }\right)\end{array}$ \\
\hline $\begin{array}{c}\text { Marwar } \\
\text { phyllite }\end{array}$ & 74.26 & 141.3 & 52.33 & 166.02 & 124.4 & 143.68 \\
\hline $\begin{array}{c}\text { Kharchi } \\
\text { junction } \\
\text { phyllite }\end{array}$ & 78.16 & 97.2 & 49.88 & 95.78 & 117.7 & 118.59 \\
\hline
\end{tabular}

\subsection{Model calibration}

The model is calibrated by matching computed heads from the model with the field measured values of heads within acceptable range of error (Anderson and Woessner, 2002). The match is achieved by changing values of model input parameters. The field measured values of heads and flows represent the calibration target. The main purpose of model calibration is to ascertain that errors between simulated and measured values are at minimum. If the model does not meet calibration criteria, i.e., the simulated heads do not match the measured values, the numerical model has to be modified or in some instances the conceptual model as well. The calibration process is repeated until a satisfactory match is obtained. It is also necessary to account for the errors associated with model calibration to determine accuracy of the numerical model to reproduce the system behavior. 
In this study, hydraulic heads were used as the calibration target. The model was calibrated using trial-and-error calibration techniques, and statistical and graphical techniques were used to justify the calibration process.

\subsubsection{Trial-and-error calibration}

Trial-and-error calibration typically requires repeated manual adjustment of input parameters and model runs until convergence is reached and a satisfactory level of match is obtained between the simulated and observed heads. To obtain best overall agreement between simulated and observed heads, most adjustment were made to the poorly known parameters and the best-known parameters were varied as little as possible. After each model run, simulated and observed heads were compared using contour plots and statistical methods to evaluate the errors associated with the calibration process.

\subsubsection{Evaluation of trial-and-error calibration}

To quantify the errors associated with the calibration process, paired data testing was applied where simulated and observed values were compared for each location. For this purpose, traditional calibration measures were used, which included Mean Error (ME), Mean Absolute Error (MAE), and Root Mean Square Error (RMSE) (Anderson and Woessner, 2002). Normalized Root Mean Square Error (NRMSE) and Normalized Objective Function (NOF) were also used to gain additional confidence in the model.

ME is the mean of the difference between simulated head $\left(\mathrm{H}_{\mathrm{s}}\right)$ and observed heads $\left(\mathrm{H}_{\mathrm{o}}\right)$ : 


$$
M E=\frac{\sum_{i=1}^{N}\left(H_{S}-H_{o}\right)_{i}}{N}
$$

where, $\mathrm{H}$ is the groundwater level, $\mathrm{i}$ is the code number of the observation well, $\mathrm{N}$ is the number of observation wells and the subscripts $\mathrm{s}$ and o stand for simulated and observed water level values respectively.

MAE is the sum of absolute value of differences between the simulated and observed heads divided by the number of observations:

$$
M A E=\frac{\sum_{i=1}^{N}\left|\left(H_{S}-H_{0}\right)_{i}\right|}{N}
$$

RMSE, also know as Standard Deviation, is the square root of the mean of squared differences between the simulated and observed heads:

$$
R M S E=\sqrt{\left[\frac{\sum_{i=1}^{N}\left(H_{S}-H_{O}\right)_{i}^{2}}{N}\right]}
$$

NOF can be calculated by dividing RMSE by the mean of observed values:

$$
N O F=\frac{R M S E_{H}}{H_{m}}
$$

where, $H_{m}$ is the mean of observed values.

NRMSE is calculated by dividing RMSE by the maximum difference in the observed heads:

$$
N R M S E=\frac{R M S E_{H}}{H_{o_{\max }-H_{o_{\text {min }}}}}
$$

In general, for perfect model prediction, $H_{s_{i}}=H_{o_{i}}, \mathrm{ME}=0$, and $\mathrm{MAE}=0 . \mathrm{ME}$ is easy to calculate but should not be used as the only criterion to judge errors. This is because negative and positive differences included in the mean may significantly cancel out errors (Anderson and Woessner, 2002). Therefore, a model cannot be considered well 
calibrated even though the mean error is small. For good model calibration, RMSE should be close to zero. However, an exact match between simulated and observed heads is not always possible in real situations. Consequently, NOF and NRMSE can be used to justify model calibration. Ideally, NOF should be 0 . But model can still be considered acceptable in the range 0 to 1 (Pisinaras et. al., 2007). For NRMSE, acceptable value is less than 10\% (Gallardo et. al., 2005).

Apart from using statistical methods, scatter plots and contour maps have been used to provide visual comparison of the simulated and observed heads. In the scatter plot, a regression straight line was fitted in which the intercept was made 0:

$$
H_{s}=\gamma H_{o}
$$

where, $\gamma$ is the slope of the line.

The slope of the regression straight line was compared to the slope of the perfect match line. $\gamma$ represents that the model is underpredicted or overpredicted compared to the observed values if $\gamma$ is less than 1 or more than 1 respectively. For a perfect match, $\gamma$ should be equal to 1 . In addition, the square of the correlation coefficient $\left(R^{2}\right)$ has been calculated for the regression line. $R^{2}$ value shows the degree of correlation between the observed and simulated values. Ideally, $R^{2}$ value should be 1 for a perfect match. $\mathrm{R}^{2}$ values less than 1 will make the data scatter around the perfect match line. The lesser the value of $R^{2}$, the greater is the scatter.

\subsection{Steady-state model calibration}

The steady-state model was calibrated using groundwater level data from 168 wells, collected in the during-monsoon period in July 2006. A recharge rate of 0.0984 
$\mathrm{m} /$ year and a transmissivity of $38.15 \mathrm{~m}^{2} /$ day were used. Abstraction rates of individual wells for the same year were also applied.. This resulted in overestimation of heads. Consequently, model was calibrated by changing the values of transmissivities and recharge. However, only minor changes were made to transmissivity and the emphasis was on adjustments to recharge. 15 zones were created to input different recharge and transmissivity values. Values in these zones were modified after each model run until a good match was obtained between simulated and observed heads. For the final run, the adjacent zones having same recharge as well as transmissivity values were merged. The fully calibrated steady-state model had 12 zones for transmissivity and 10 zones for recharge. The optimized values of transmissivity and recharge are discussed in the results section. Since groundwater withdrawal was better known compared to transmissivity and recharge, it was left untouched.

\subsubsection{Steady-state model verification}

In order to ascertain that the calibrated parameters accurately represent field values, the model was checked against observed head values from 19 monitoring wells which were also collected in July 2006. A fairly good match was obtained between the simulated and observed heads which have been discussed in the results section.

\subsubsection{Steady-state model results}

\subsubsection{Hydraulic head}

The steady-state model calibration with observed heads from abstraction wells showed a relatively good match between the simulated and observed heads. Statistical evaluations of simulated and observed heads are presented in Table 5-4. 
Table 5-4. Statistical evaluations of simulated and observed heads.

\begin{tabular}{|c|c|}
\hline Statistical measure & Values \\
\hline ME & $0.11 \mathrm{~m}$ \\
\hline MAE & $5.60 \mathrm{~m}$ \\
\hline RMSE & $6.89 \mathrm{~m}$ \\
\hline NOF & 0.01 \\
\hline NRMSE & 0.10 \\
\hline
\end{tabular}

The ME is 0.11 and is very close to 0 which indicates that, on an average, the simulated heads were slightly greater than the corresponding observed heads. MAE, however, shows that the simulated heads were over-predicted by approximately $6 \mathrm{~m}$. RMSE also explains that the model over-predicted the simulated heads by over $6 \mathrm{~m}$. As discussed earlier, it is sometimes not possible to obtain an exact match for simulated and observed heads and, therefore, the model can be accepted if it meets the calibration target within an acceptable range of error.

The NOF value of 0.01 is very close to 0 , which means that the model is well calibrated and is acceptable. The NRMSE value of 0.1 also indicates that the model can be accepted.

Simulated heads are plotted against the observed heads in a scatterplot (Figure 54). The slope of regression line, $\gamma$, is very close to 1 indicating a fairly good match between the simulated and observed heads. The $R^{2}$ value of 0.65 also suggests a fairly good match. Contour maps have been plotted to show the spatial distribution of simulated and observed heads. The head contours were plotted using Surfer (version 8.06.39). 


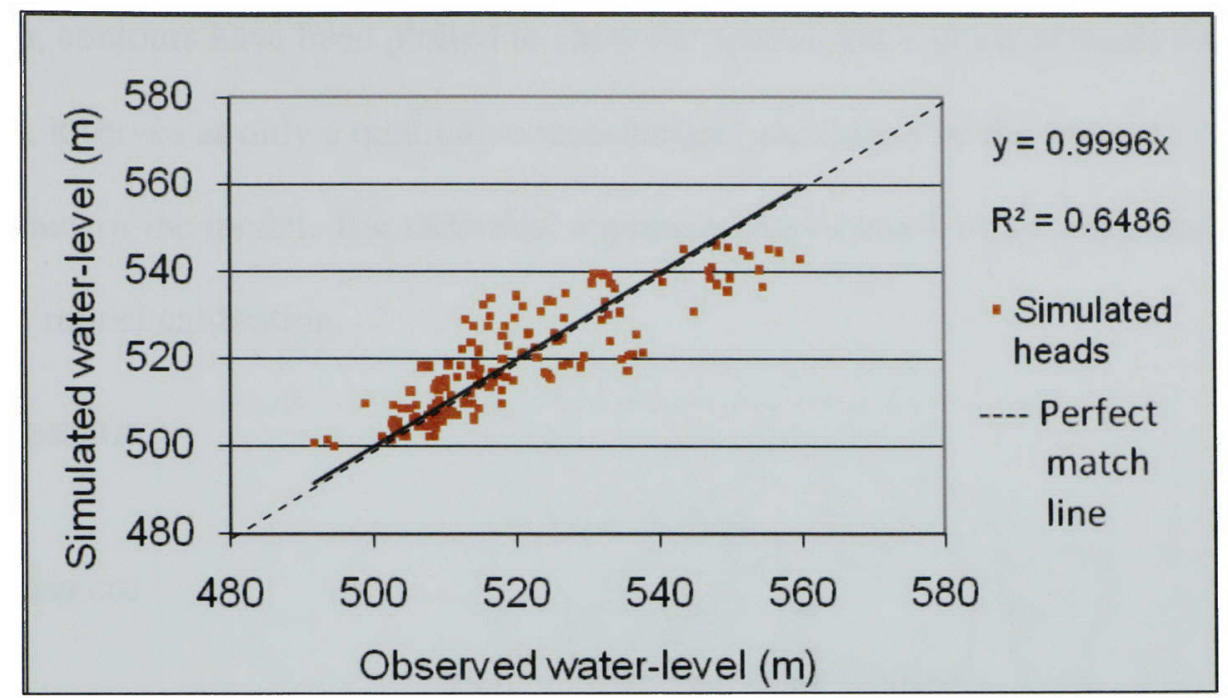

Figure 5-4. Scatterplot of simulated and observed heads.

Figure 5-5 shows the spatial distribution of simulated heads of the wells compared to observed heads with a contour spacing of $5 \mathrm{~m}$ and Figure 5-6 shows the spatial distribution of residuals between the simulated and observed heads with a contour spacing of $2 \mathrm{~m}$.

Since head data for the entire model domain were not available, the analysis was limited to only a part of the domain. The contour plot shows model calibration with mixed results. It can be seen that there is fairly good match between observed and simulated heads in most part of the domain with some exception in the western part.

The residual contour plot shows a discrepancy of $-10 \mathrm{~m}$ in the southern part and above $16 \mathrm{~m}$ in the western part. In reality though, only few wells had either underprediction or over-prediction with such a high number. This discrepancy can be explained by errors introduced during contour plotting. Since, krigging was used to plot the contour maps, it might be possible that heads from wells located too far were used to find heads at these locations due to which erroneous heads might have resulted in the contour plot. 
Although, contours have been plotted to show the spatial distribution of heads and residuals, it serves as only a qualitative measure and should not be the criteria to judge the accuracy of the model. The statistical approach gives a much better understanding about the model calibration.

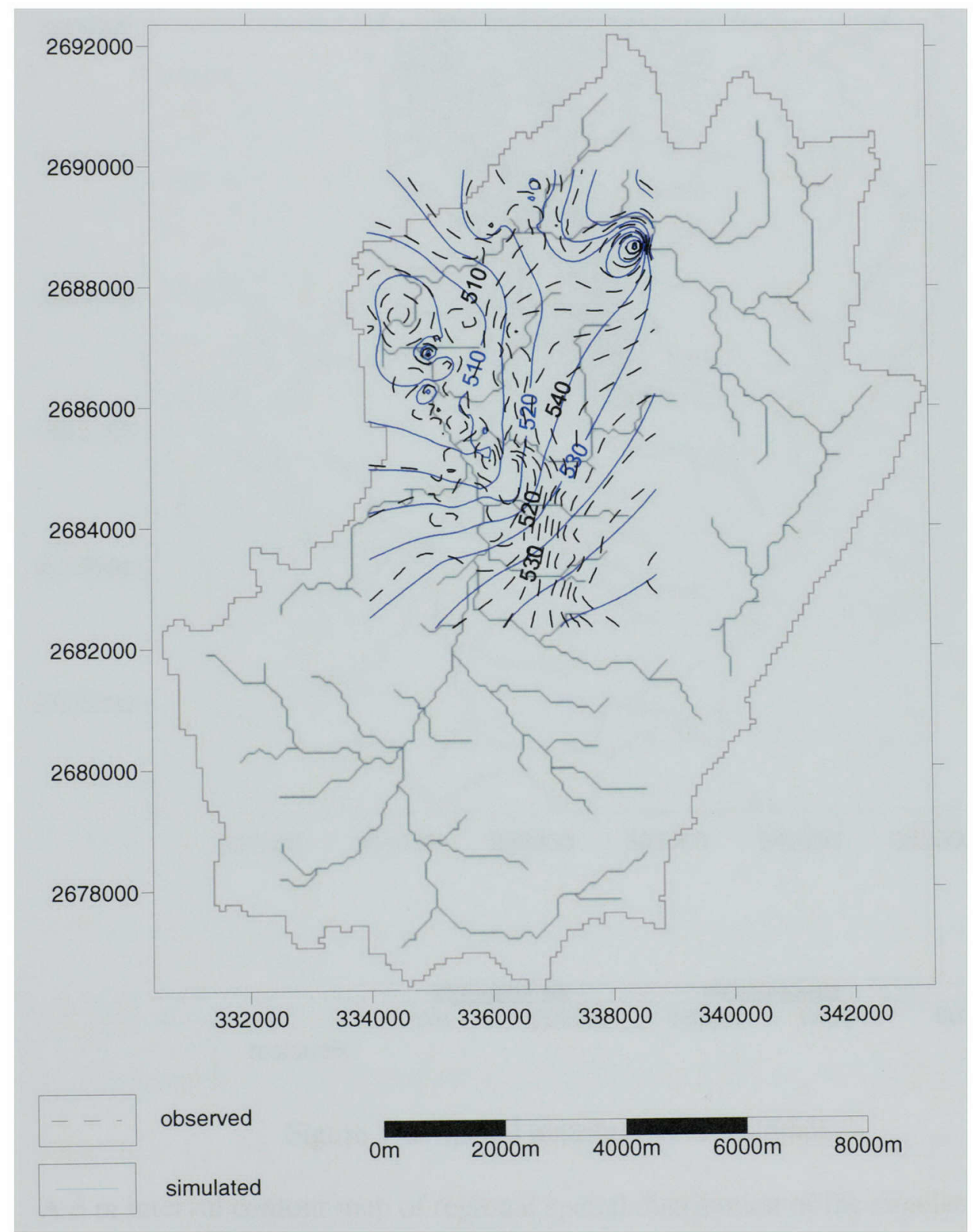

Figure 5-5. Comparison of spatial distribution of simulated heads and observed heads. 


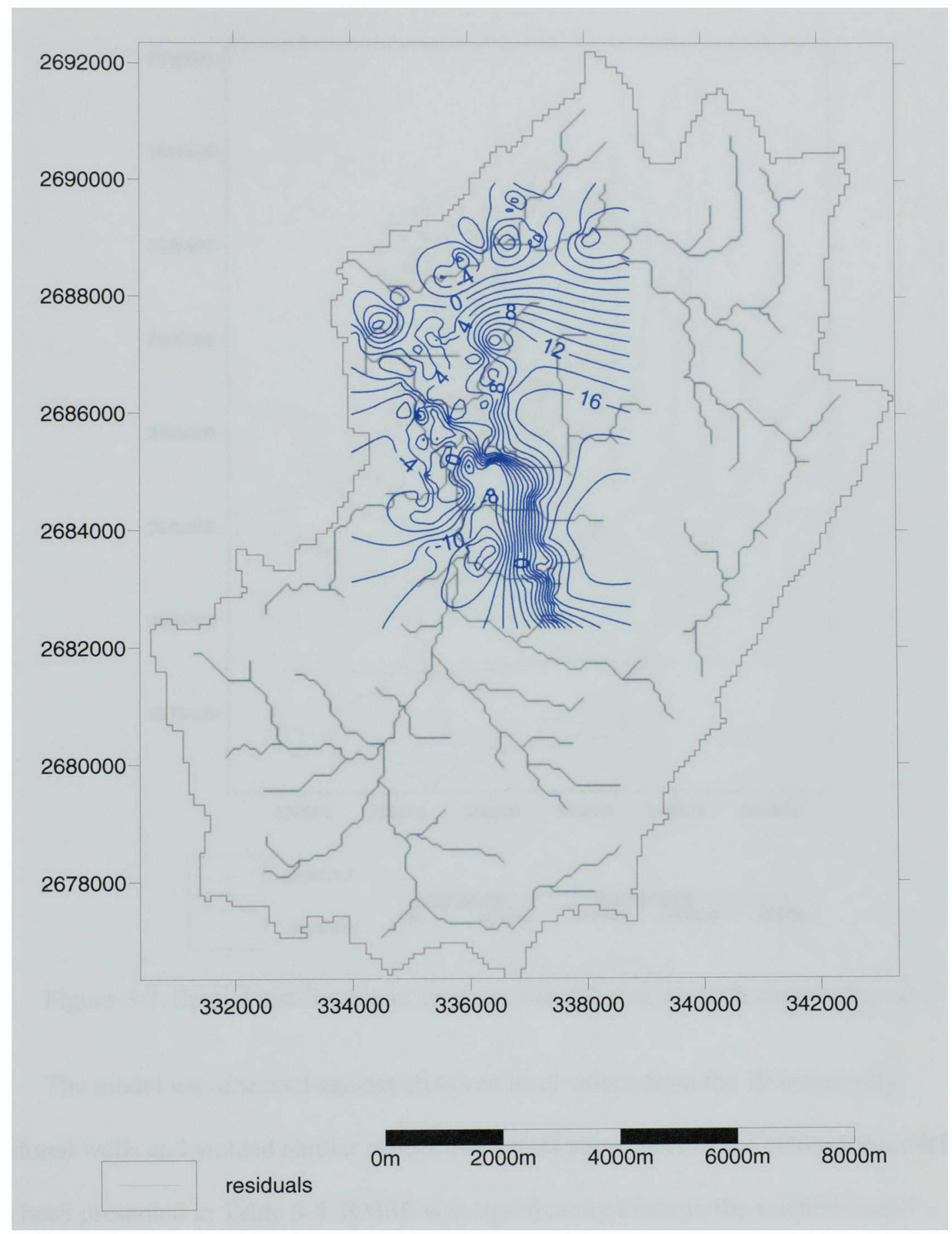

Figure 5-6. Spatial distribution of residuals.

A $5 \mathrm{~m}$ interval contour map of regional spatial distribution of the simulated heads together with the observed heads has also been provided (Figure 5-7). 
between simulated and observed heads with $\gamma$ and $R^{2}$ value of 0.99 and 0.60 respectively (Figure 5-8).

Table 5-5. Statistical parameters of the verified model.

\begin{tabular}{|c|c|}
\hline Statistical measure & Values \\
\hline ME & $1.61 \mathrm{~m}$ \\
\hline MAE & $5.54 \mathrm{~m}$ \\
\hline RMSE & $2.18 \mathrm{~m}$ \\
\hline NOF & 0.00 \\
\hline NRMSE & 0.05 \\
\hline
\end{tabular}

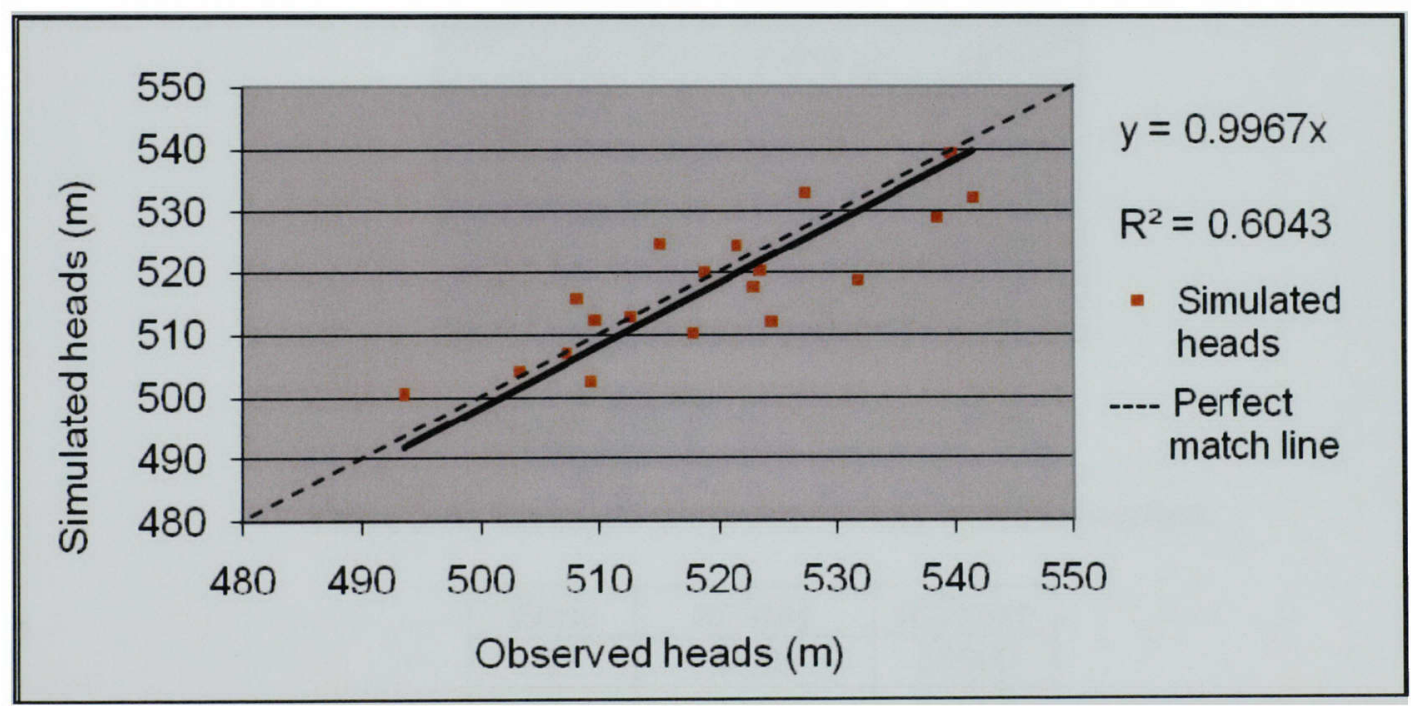

Figure 5-8. Scatter plot of simulated and observed heads of the verified model.

The simulated regional heads from the verified model were later used as initial conditions for setting the transient model. The observed heads in the 19 monitoring wells were also used to calibrate the transient model. 


\subsubsection{Transmissivity}

Besides recharge, transmissivity was the most uncertain parameter in the model.

Transmissivity values were adjusted in different zones. These zones are shown in Figure 5-9 and the values of corresponding zones are provided in Table 5-6. The transmissivity values varied between $27-50 \mathrm{~m}^{2} / \mathrm{d}$.

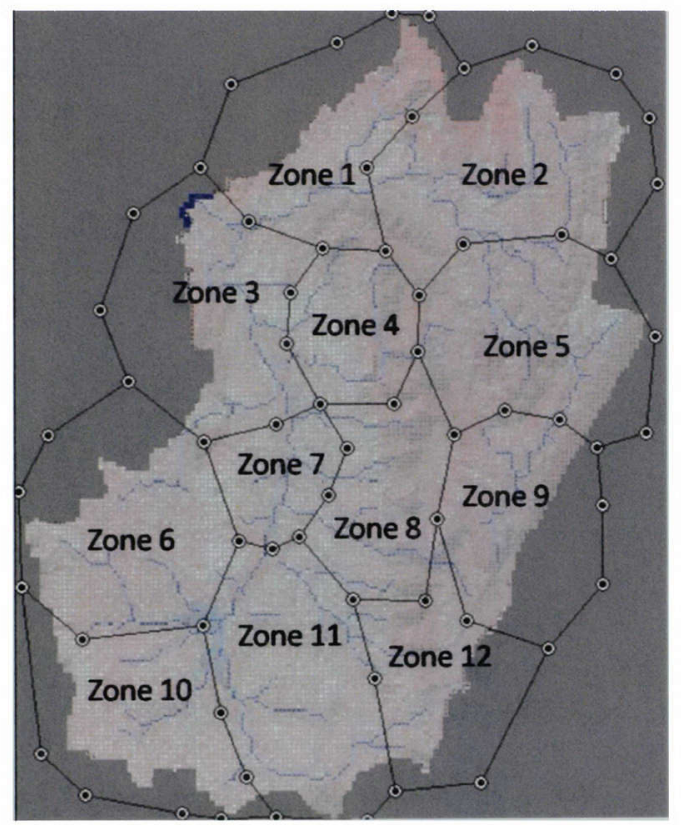

Figure 5-9. Transmissivity zones.

Table 5-6. Variation of transmissivity in various zones.

\begin{tabular}{|c|c|c|}
\hline Zone & $\mathbf{~}^{\mathbf{2}} /$ day & $\mathbf{m}^{\mathbf{2}} /$ year \\
\hline 1 & 38.36 & 14000 \\
\hline 2 & 32.88 & 12000 \\
\hline 3 & 49.32 & 18000 \\
\hline 4 & 49.32 & 18000 \\
\hline 5 & 30.14 & 11000 \\
\hline 6 & 32.88 & 12000 \\
\hline 7 & 35.62 & 13000 \\
\hline 8 & 38.36 & 14000 \\
\hline 9 & 27.40 & 10000 \\
\hline 10 & 32.88 & 12000 \\
\hline 11 & 35.62 & 13000 \\
\hline 12 & 35.62 & 13000 \\
\hline
\end{tabular}




\subsubsection{Recharge}

Recharge was also adjusted throughout the model domain in different zones. In total, 10 zones were created. The zones are shown in Figure 5-10 and the calibrated values are listed in Table 5-7.

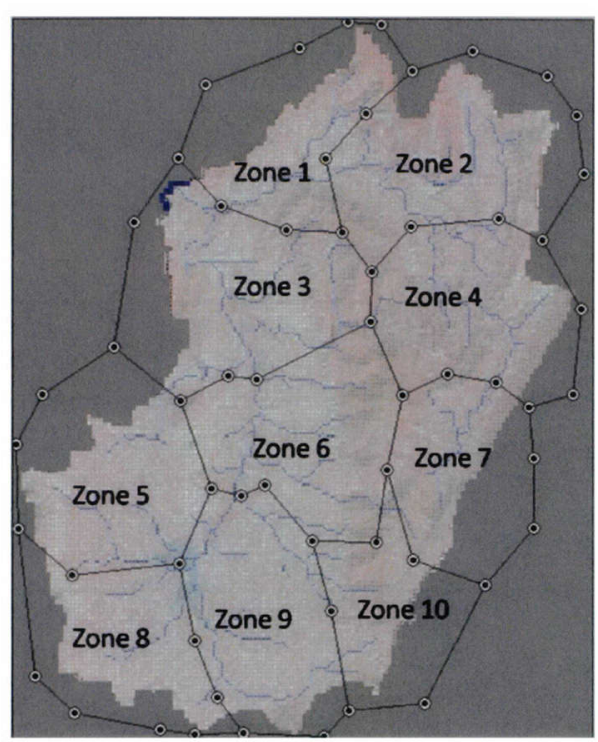

Figure 5-10. Recharge zones.

Table 5-7. Variation of recharge in different zones.

\begin{tabular}{|c|c|c|}
\hline Zones & $\mathbf{m} / \mathbf{d a y}$ & $\mathbf{m} /$ year \\
\hline 1 & $8.63 \times 10^{-4}$ & $3.15 \times 10^{-2}$ \\
\hline 2 & $6.47 \times 10^{-4}$ & $2.36 \times 10^{-2}$ \\
\hline 3 & $9.44 \times 10^{-4}$ & $3.45 \times 10^{-2}$ \\
\hline 4 & $8.09 \times 10^{-4}$ & $2.95 \times 10^{-2}$ \\
\hline 5 & $2.70 \times 10^{-5}$ & $9.84 \times 10^{-3}$ \\
\hline 6 & $9.44 \times 10^{-4}$ & $3.45 \times 10^{-2}$ \\
\hline 7 & $2.70 \times 10^{-5}$ & $9.84 \times 10^{-3}$ \\
\hline 8 & $2.70 \times 10^{-5}$ & $9.84 \times 10^{-3}$ \\
\hline 9 & $2.70 \times 10^{-5}$ & $9.84 \times 10^{-3}$ \\
\hline 10 & $2.70 \times 10^{-5}$ & $9.84 \times 10^{-3}$ \\
\hline
\end{tabular}




\subsubsection{Groundwater budget}

The groundwater budget for the steady-state calibrated model using monitoring well observation heads for calibration is presented in Table 5-8.

Table 5-8. Groundwater budget of verified model.

\begin{tabular}{|c|c|c|c|}
\hline Flow term & $\begin{array}{c}\text { Inflow } \\
\text { (MCM/year) }\end{array}$ & $\begin{array}{c}\text { Outflow } \\
\text { (MCM/year) }\end{array}$ & $\begin{array}{c}\text { Inflow - outflow } \\
\text { (MCM/year) }\end{array}$ \\
\hline Recharge & 2.44 & - & 2.44 \\
\hline Constant head & - & 0.37 & -0.37 \\
\hline Wells & - & 2.07 & -2.07 \\
\hline (Abstraction) & & & 0.00 \\
\hline Total & 2.44 & 2.44 & \\
\hline Discrepancy (\%) & 0.00 & & \\
\hline
\end{tabular}

The groundwater budget is consistent with steady-state modeling approach and shows a perfect balance between the total inflows and outflows of water. The aquifer receives all the water from rainfall which amounts to more than $2 \mathrm{MCM} / \mathrm{year}$. This is about $2 \%$ of the volume of annual precipitation which is estimated to be more than 116 $\mathrm{MCM} /$ year.

\subsection{Transient-state model calibration}

The calibration of the steady-state model was followed by development of a transient-state model. The hydraulic head obtained from the steady-state calibration was used as the initial condition of the transient-state model. A transient-state model requires 
transient head data recorded over several years and the storage of the aquifers to be specified in addition to the steady-state condition input requirements. Historical groundwater level data for the wells in study area do not exist. An approximate range of storage coefficient values for the study area were obtained from literature review (Table 4-3). However, single storage coefficient values might not represent the entire area and therefore might need to be significantly adjusted. In the absence of historical groundwater data, the only way to adjust storage coefficient values was to compare the model with observed head data recorded over a period of a little over 2 months in 2006. To get an approximate estimate of the storage coefficient, the model was run consecutively for at least 5 years with the same pattern of monsoonal/non-monsoonal recharge and by changing the storage coefficient. The idea was to let the aquifer stabilize and repeat similar head response over these years (Figure 5-11).

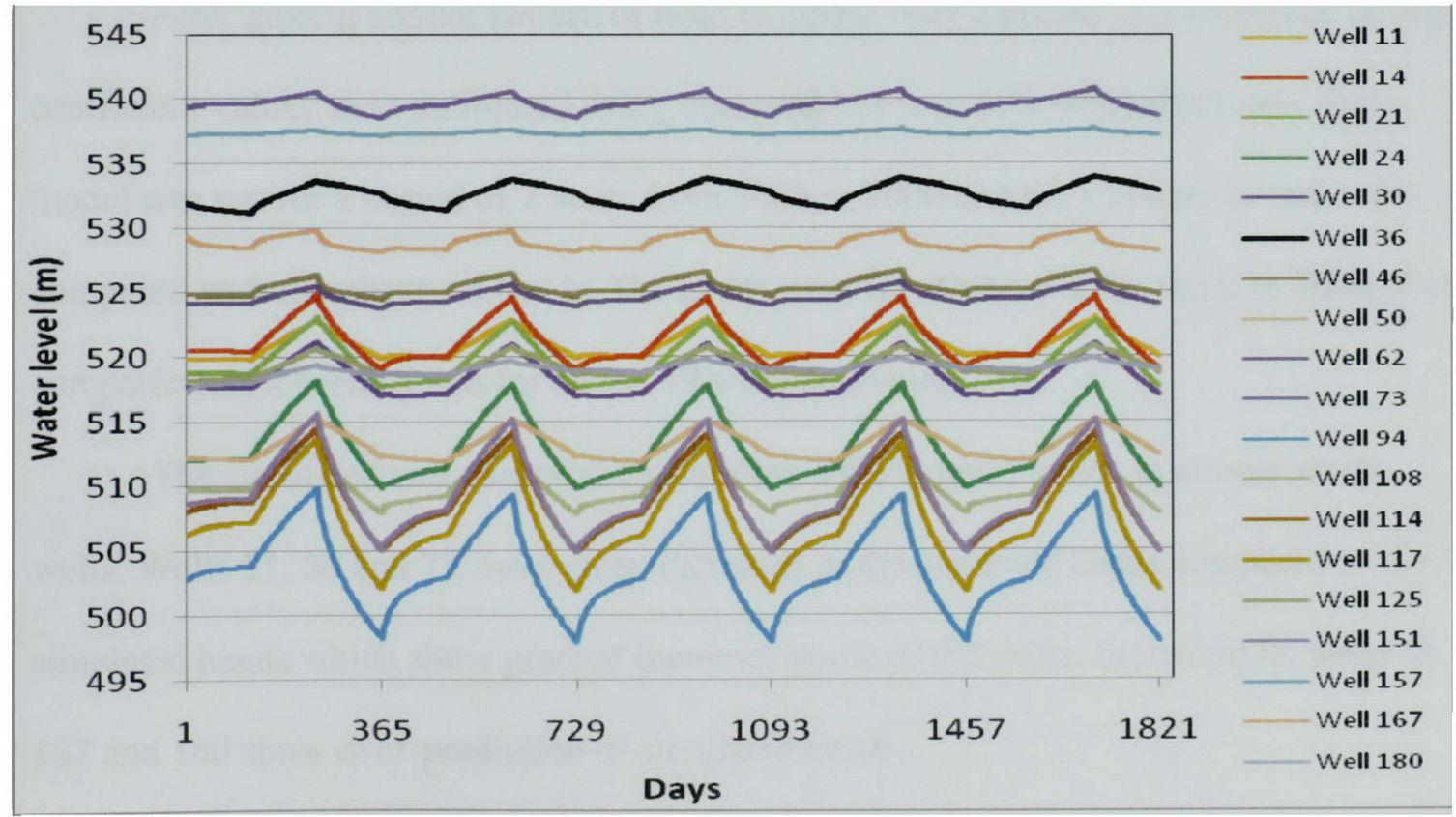

Figure 5-11. Head response of 19 monitoring wells during a period of 5 years. 
During this procedure, total simulation times of 5 years were divided into 15 stress periods, each year having 3 stress periods. Each stress period of a year was subdivided into 122, 123 and 120 days representing summer, monsoon and winter seasons. Each stress period was divided into 30 time steps. Calibrated recharge and transmissivity values from the steady-state model were applied to the transient state model in $\mathrm{m} / \mathrm{day}$ and $\mathrm{m}^{2} /$ day respectively. Recharge was applied only during the monsoon season and different groundwater withdrawal rates were applied for summer and winter season. The groundwater withdrawal rate is higher in winter compared to summer. The simulation time unit was set to days. Figure 5-11 shows the head response of the monitoring wells for a period of 5 years.

\subsubsection{Transient-state model results}

After getting similar pattern of head response over a period of 5 years, the storage coefficient values were calibrated using observed heads in 19 monitoring wells. The model was run for a period of 2 years from 2005 to 2006 and the simulated heads were compared with the observed heads. The heads used for 2005 were the same as 2006 . The comparison has been shown for all the 19 wells in Figure 5-12.

The simulated and observed heads show a fairly good match in almost all the wells. Wells 21,36 and 73 show steep increases in the observed heads compared to the simulated heads which show gradual increase. Some of the wells, for example, wells 46 , 167 and 180 show over-prediction of simulated heads. 

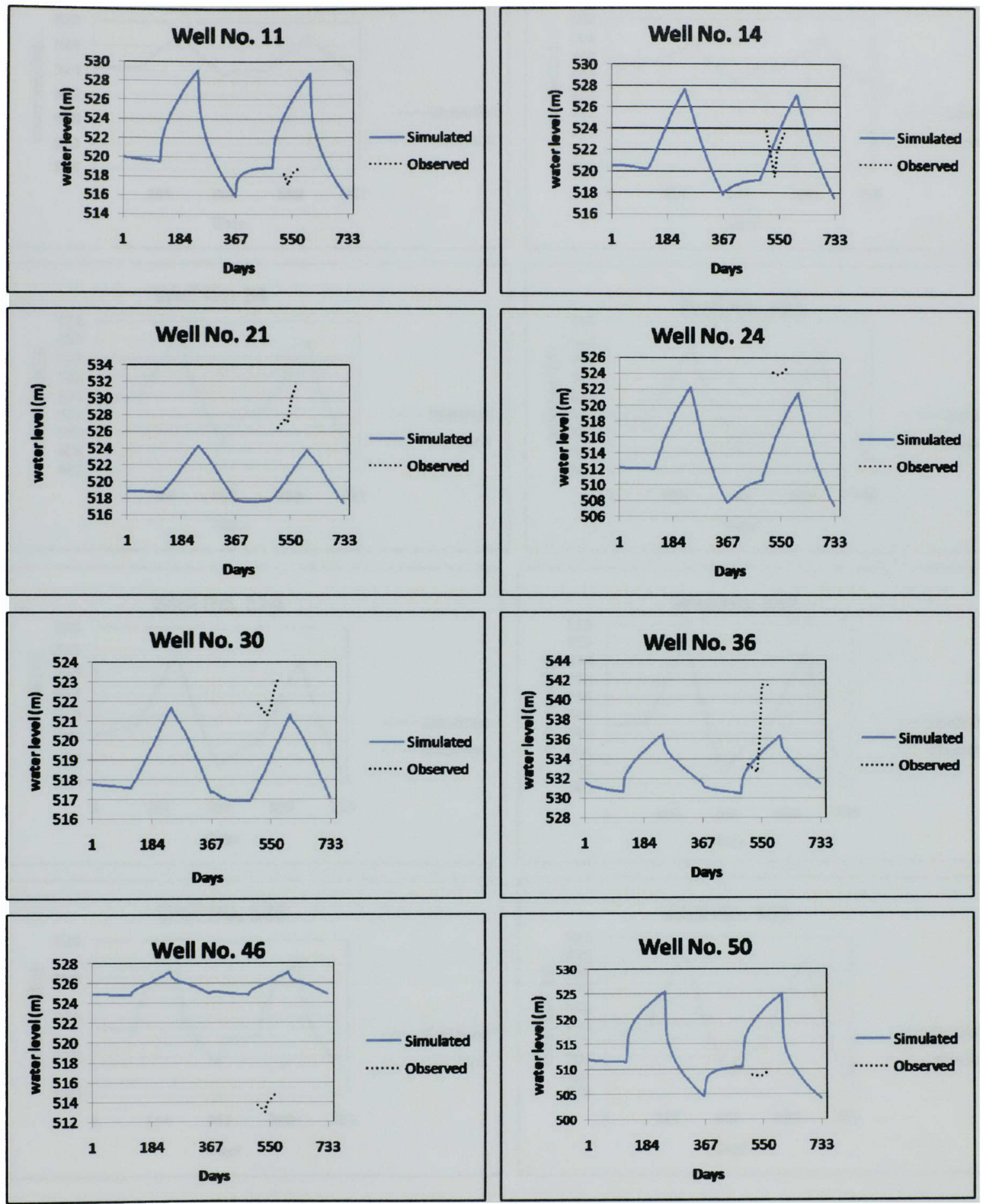

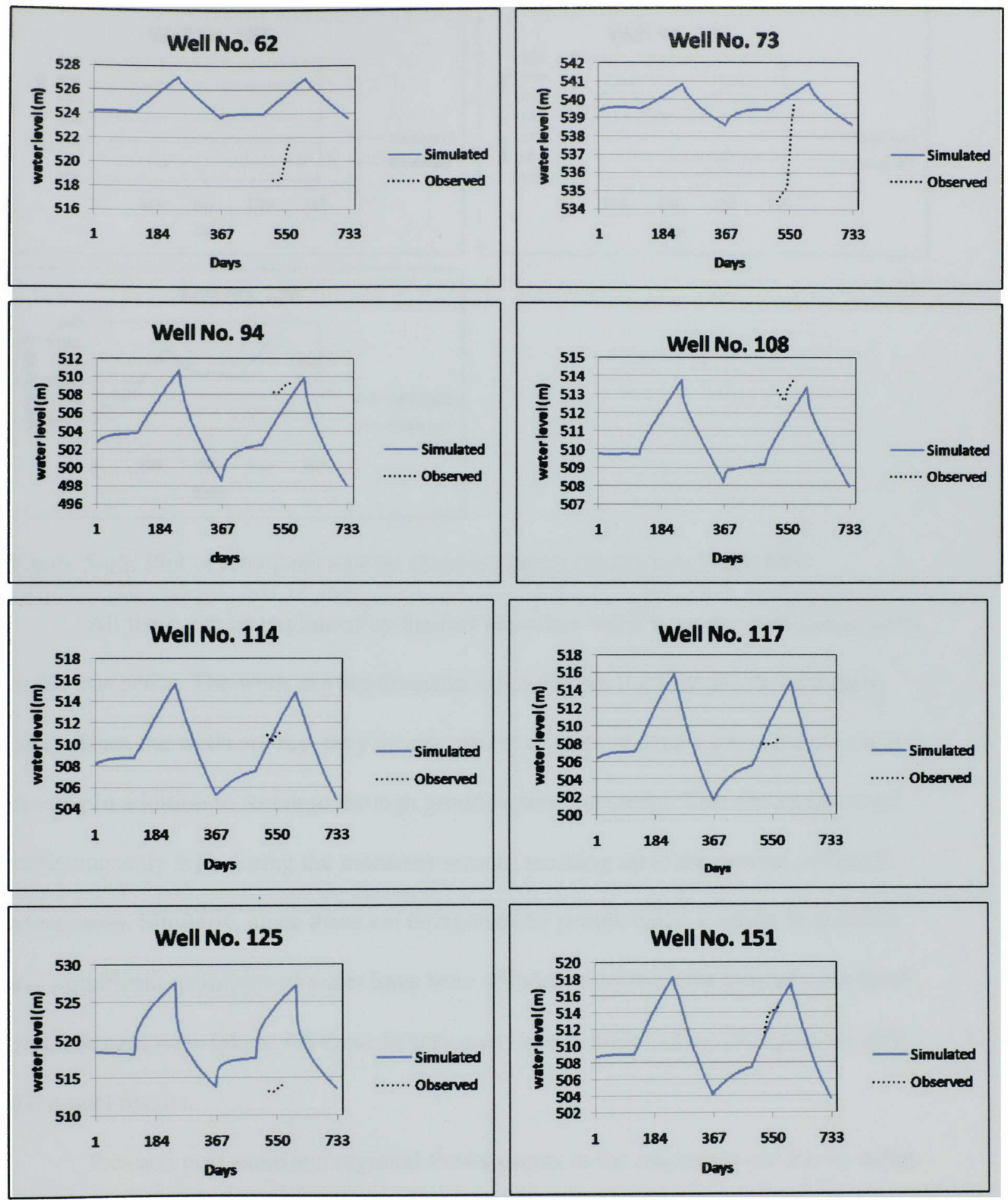

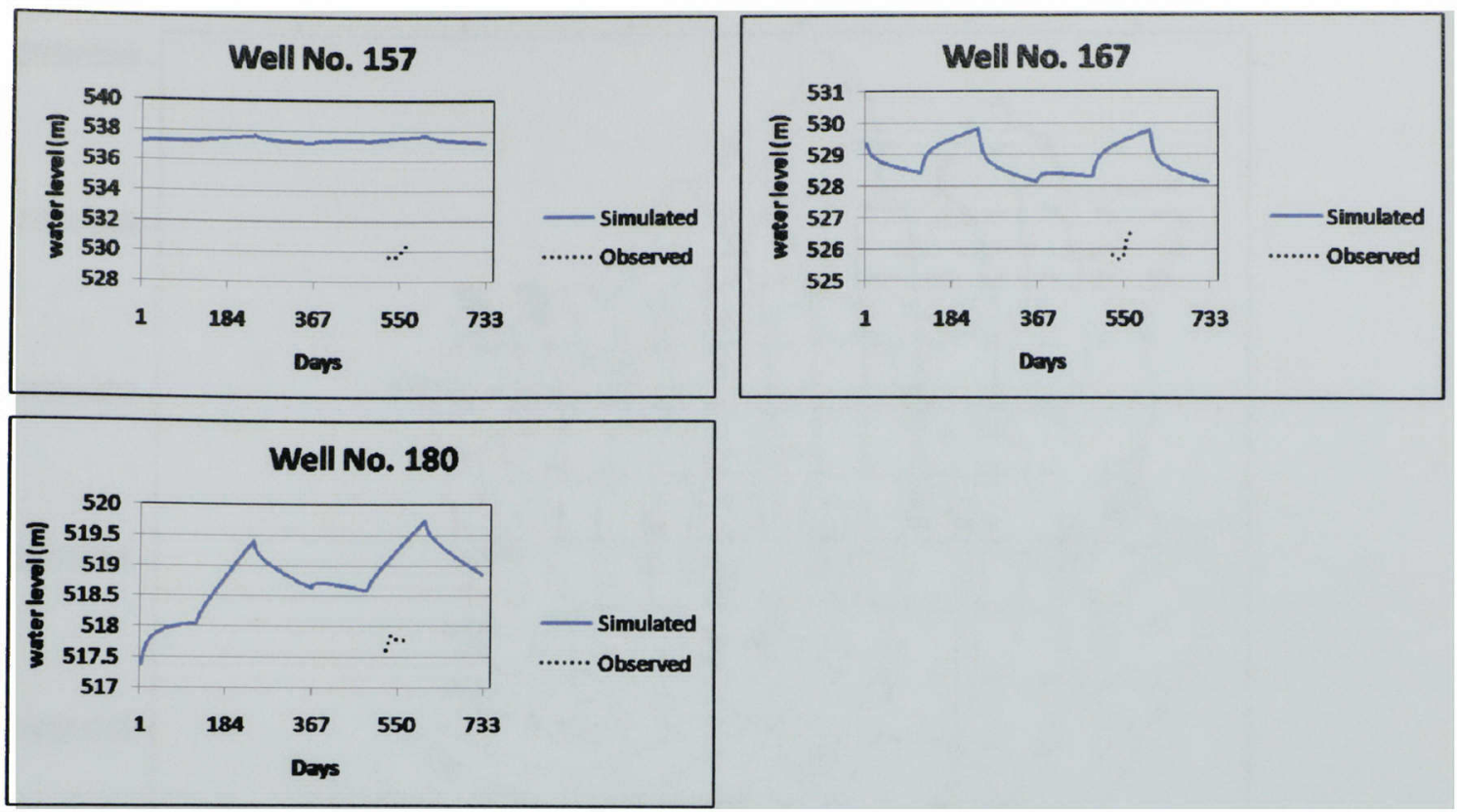

Figure 5-12. Plot of simulated against observed heads for the year 2005-2006.

All these can be explained by the fact that these wells were not monitoring wells in the true sense. The wells are big diameter wells that are used by people on a daily basis. Since the wells are big, they receive plenty of water during a precipitation event directly in addition to recharge through groundwater movement. This makes the water table unusually high during the monsoon season, reaching up to the ground surface in some cases. Similarly, since these are being used by people daily, it might be possible that significant quantities of water have been withdrawn by the time groundwater level measurement were taken. All these factors may have contributed to discrepancies with the model results.

Pre- and post-monsoon regional flow patterns in the catchment are shown using water level contour map and ground water velocity vectors in Figure 5-13. 


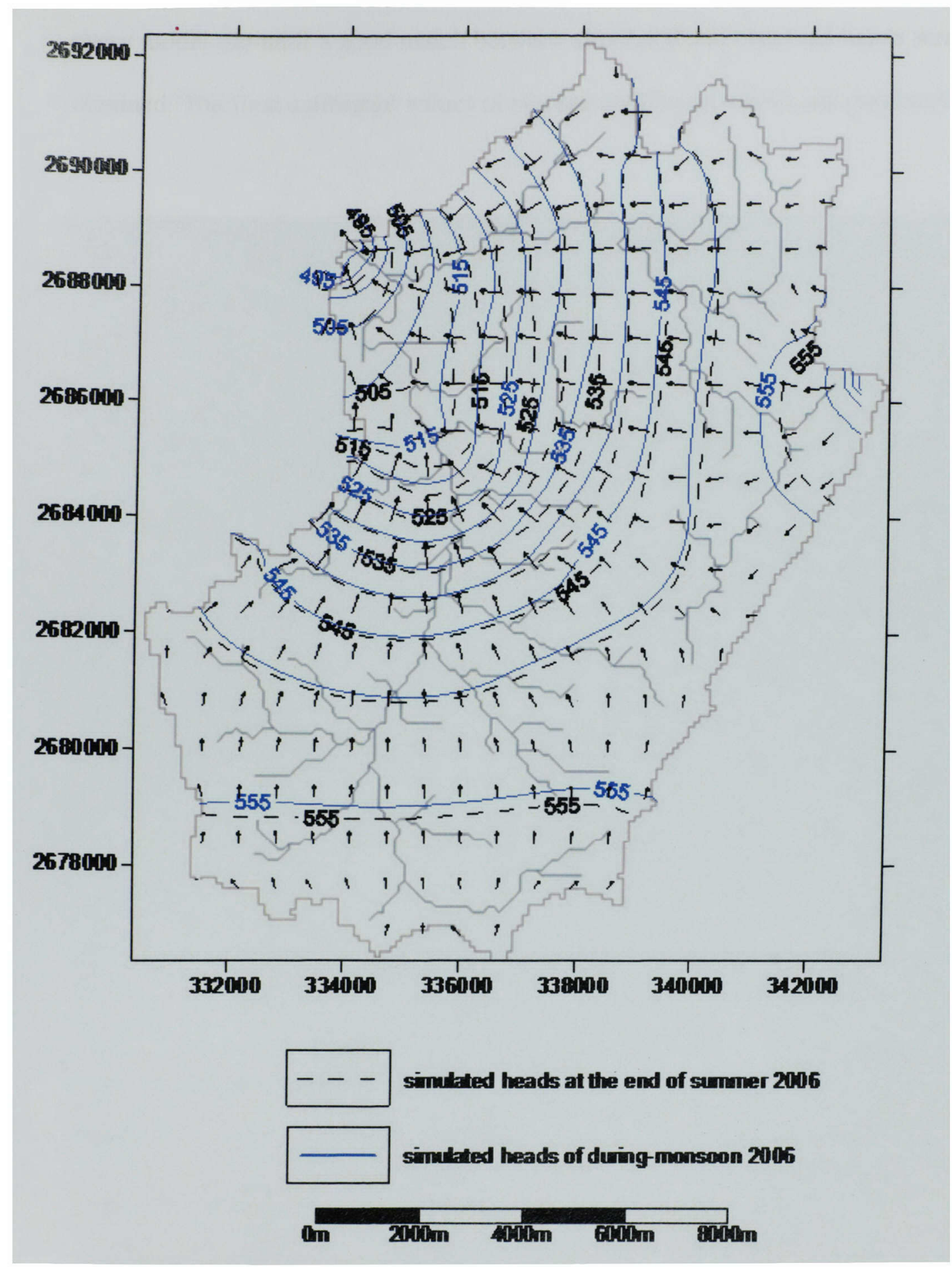

Figure 5-13. Map showing the pre- and during-monsoon groundwater level of 2006 and groundwater velocity vectors.

During transient-state model calibration, the storage coefficients had to be adjusted. This was done by creating 14 zones and adjusting values in each zone after 
every model run until a good match between simulated and observed heads were obtained. The final calibrated values of storage coefficient values are presented in Figure $5-14$.

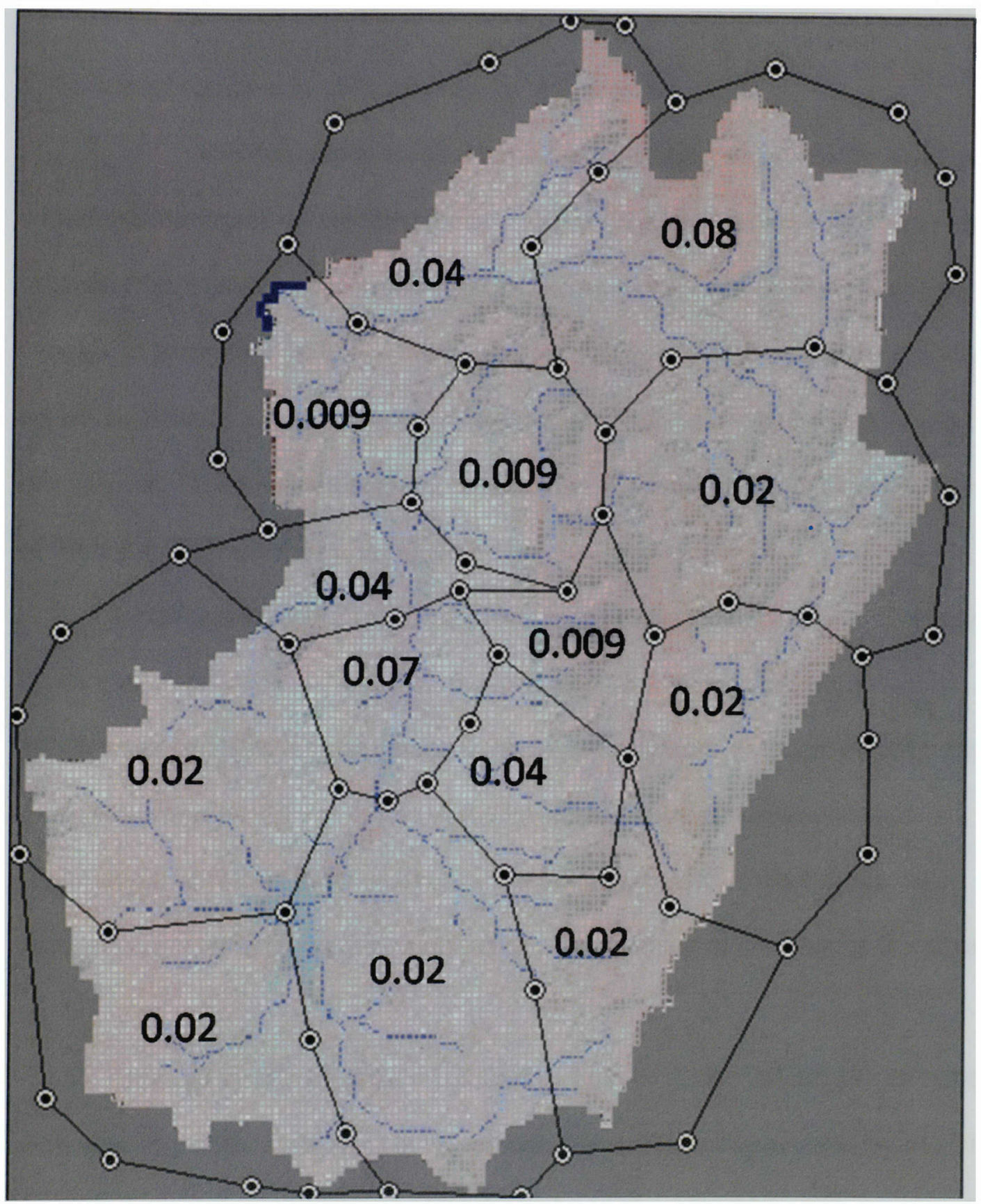

Figure 5-14. Variation of storage coefficient in different zones. 


\subsection{Model prediction}

Management scenarios were formulated to evaluate the impacts of current pumping schedules and propose solutions to potential overdraft conditions.

\subsubsection{Model scenario 1: $15 \%$ increase in withdrawal}

This scenario is predicated on recharge being unaffected by changes in withdrawal. Increases in withdrawal might allow additional recharge. The model was run to predict the regional groundwater head in the catchment until the year 2010 with an increase in abstraction by $15 \%$ in the year 2008-2010 and normal rainfall condition. The initial and boundary conditions to calibrate transient model for 2006 has been used for this purpose. The simulated regional groundwater heads at the end of the monsoon season of 2006 and 2010 are shown in Figure 5-15.

It can be seen that groundwater level in the eastern part of the catchment declines by the end of monsoon season in 2010. Apart from that, no significant changes in groundwater levels have been observed. The simulated heads of the monitoring wells were plotted against time to have a closer look at the response of the aquifer. Hydrographs of four of these wells are shown in Figure 5-16. It can be seen that groundwater level in all the four monitoring wells declined in the range of 0.5 to about 4 m.

Although most part of the catchment will not be greatly affected by increase in withdrawal by $15 \%$, wells lying in the western part can have significant impact on the groundwater levels as demonstrated by the hydrograph of Well No. 151. Locally, This calls for some immediate measures to check the withdrawal situation in this area. 


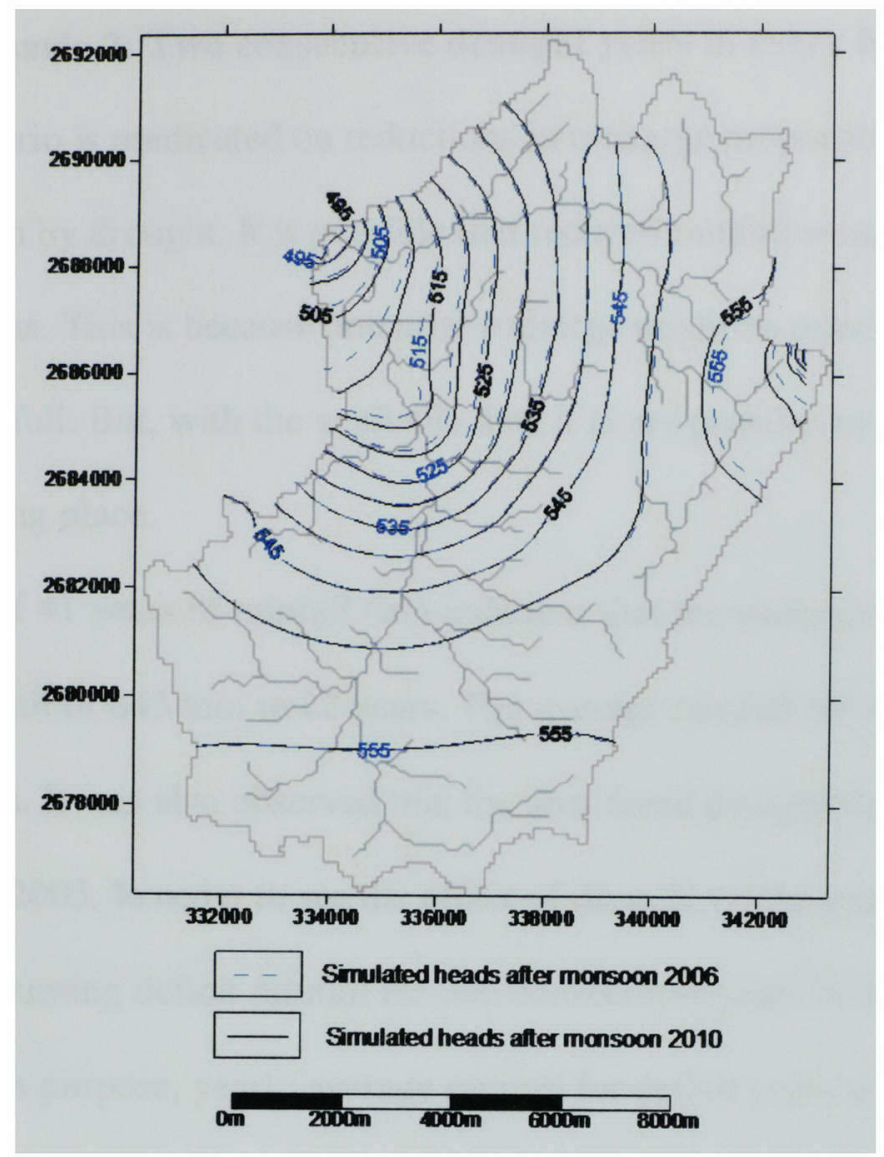

Figure 5-15. Contour plot of simulated heads after monsoon of 2006 and 2010.
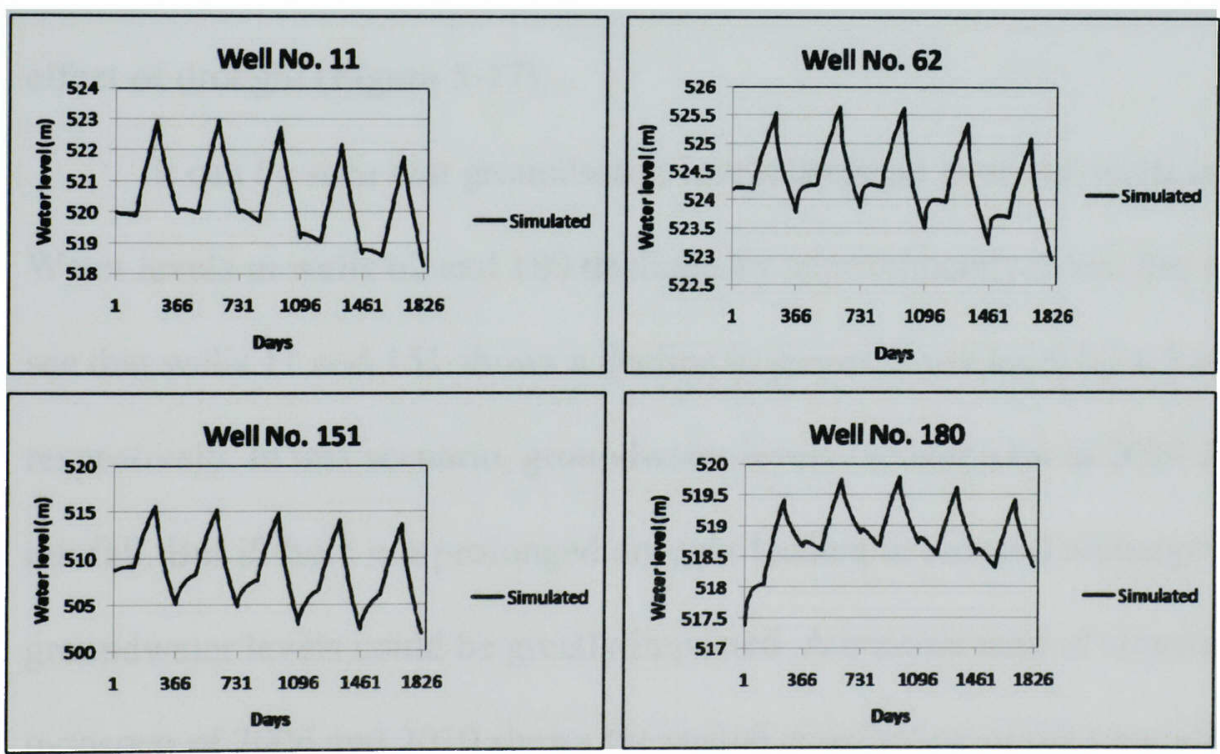

Figure 5-16. Simulated heads of wells through December 2010 under increased pumping conditions by $15 \%$ 


\subsubsection{Model scenario 2: Two consecutive drought years in every four years}

This scenario is predicated on reductions in recharge proportional to reductions in rainfall brought on by drought. It is possible that reduced rainfall would not lead to recharge reductions. This is because potential recharge might be rejected when the low storage aquifer is full. But, with the available data it is not possible to know if such rejections are taking place.

Analysis of 41 years of rainfall data indicates that the study area received less than average rainfall of $645 \mathrm{~mm}$ in 22 years. The average rainfall for these low rainfall years was $484 \mathrm{~mm}$. It was also observed that the area faced drought for 7 consecutive years from $1999-2005$. In order to see the effect of drought on the groundwater levels, model was run assuming deficit rainfall for two consecutive years in every four years until 2010. For this purpose, yearly average rainfall for deficit years was used for drought years and rainfall of 2006 was used for normal years. Abstraction was maintained at present rate. Simulated heads of four wells have been plotted against time to see the effect of drought (Figure 5-17).

It can be seen that groundwater levels declined in all the wells in drought years. Water levels in wells 62 and 180 declined by approximately $0.5 \mathrm{~m}$. But one can clearly see that wells 11 and 151 shows a decline in groundwater level by 1.5 and $3 \mathrm{~m}$ respectively. In this scenario, groundwater levels recover a bit in 2010 due to normal rainfall. But if there is a prolonged drought leading to reduced recharge in the region, groundwater levels could be greatly impacted. A contour map of simulated heads after monsoon of 2006 and 2010 shows the spatial distribution of the groundwater level changes (Figure 5-18). 

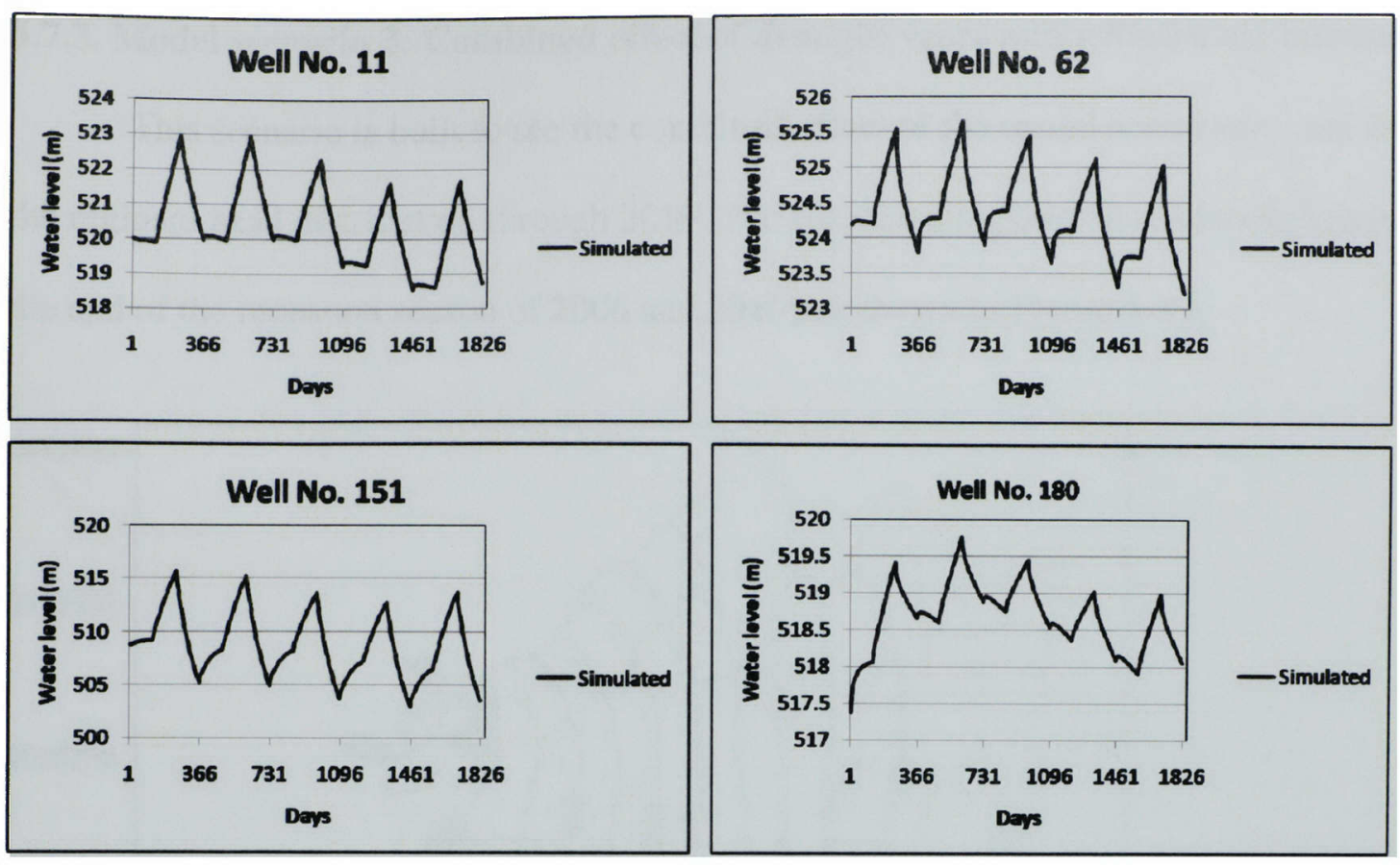

Figure 5-17. Simulated heads of wells until 2010 under drought scenario.

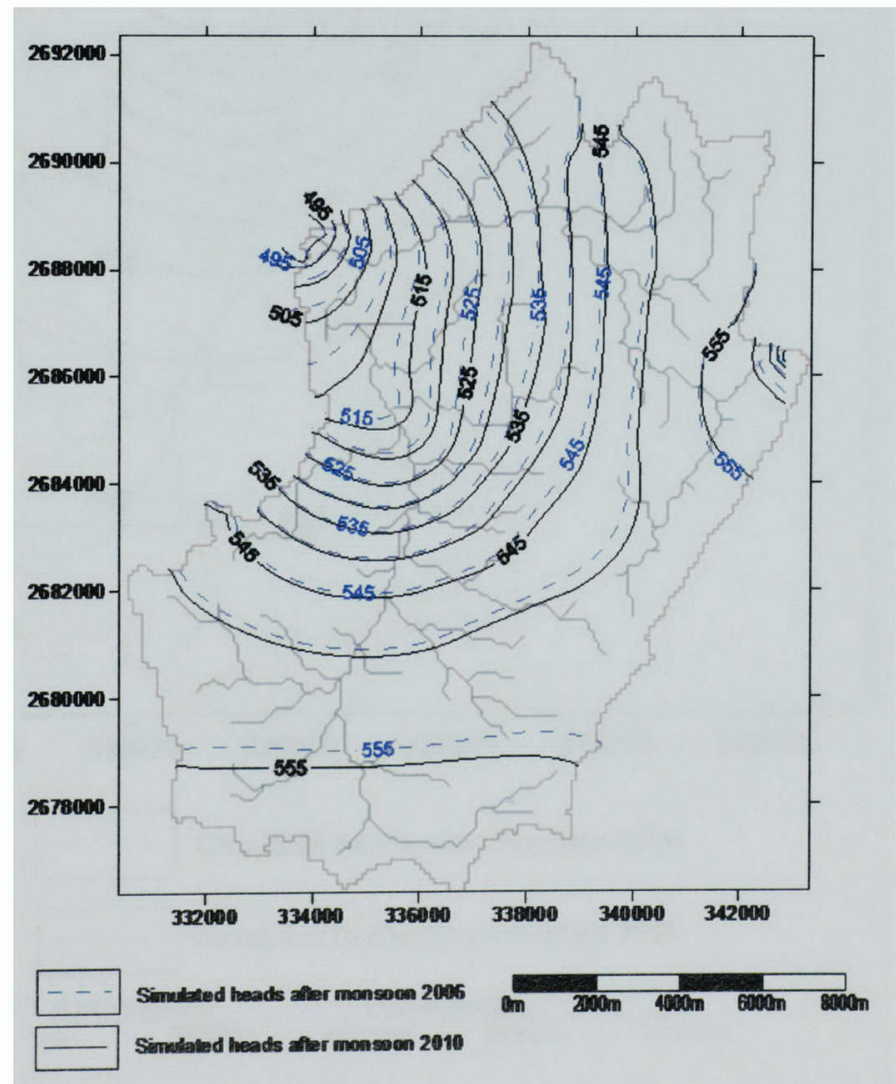

Figure 5-18. Comparison of simulated heads after monsoon of 2006 and 2010. 


\subsubsection{Model scenario 3: Combined effect of drought years and withdrawal increase}

This scenario is built to see the combined effect of the model scenarios 1 and 2 on the regional head distribution through 2010. The simulated regional groundwater heads at the end of the monsoon season of 2006 and 2010 are shown in Figure 5-19.

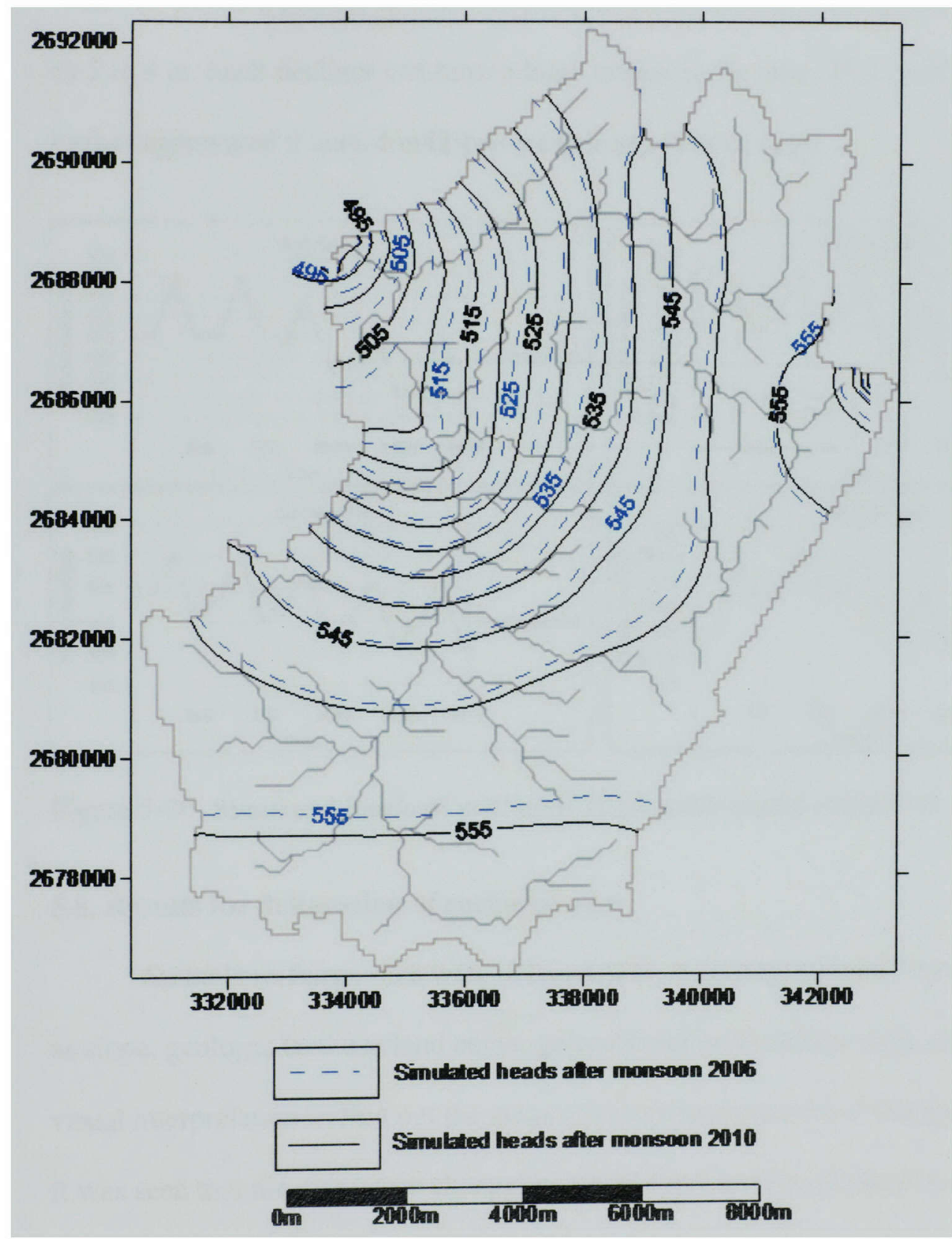

Figure 5-19. Comparison of simulated heads after monsoon of 2006 and 2010 
It is clear that if the catchment faces drought years and at the same time the withdrawal is increased by $15 \%$, the decline in groundwater levels can be catastrophic for the entire catchment. It can be seen that the groundwater levels have declined in the entire catchment. The hydrographs of four of the monitoring wells is shown in Figure 5-20.

Well 180 shows a decline of about $1 \mathrm{~m}$, but in the remaining wells groundwater declines by 2 to $9 \mathrm{~m}$. Such declines can have a huge impact in the area. This problem can be further aggravated if such conditions are prolonged in the area.
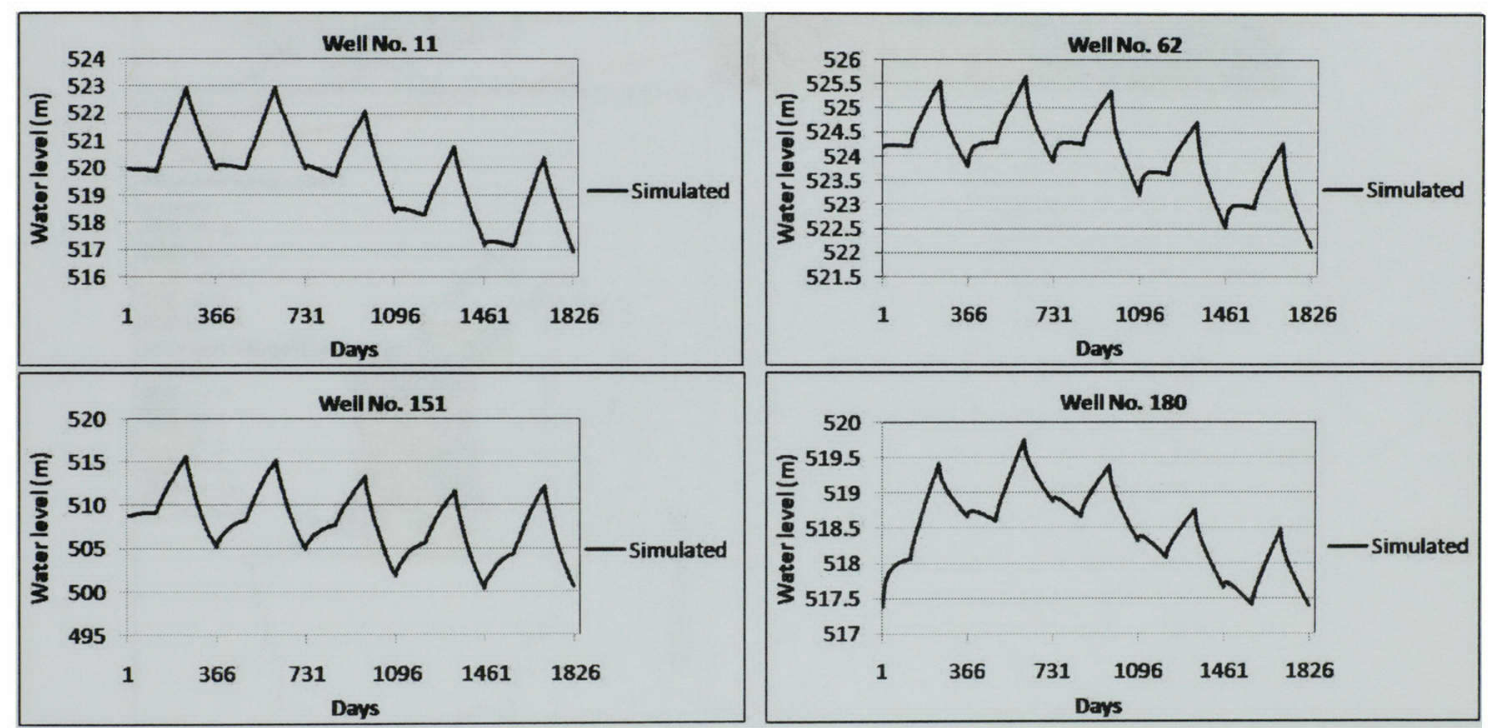

Figure 5-20. Simulated heads of well until 2010 under model scenario 3.

\subsection{Results for delineation of recharge sites}

Suitable recharge sites were delineated by superimposition of various layers such as slope, geology, land use/land cover, groundwater level change map, etc. and making a visual interpretation to find out the areas where groundwater level change was maximum. It was seen that the maximum change in groundwater level took place in areas with good forest cover and high NDVI (Figure 5-21). 


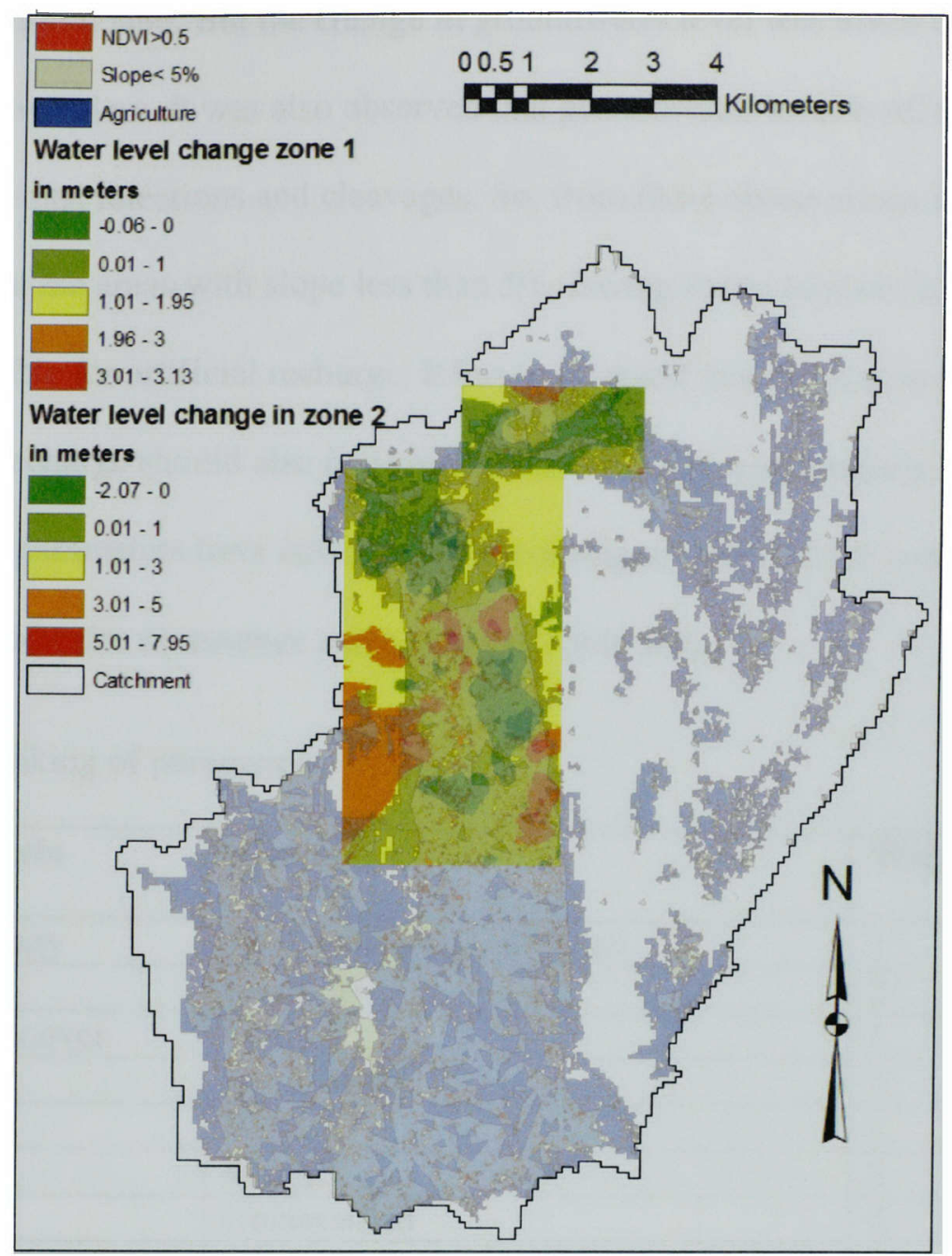

Figure 5-22. Map showing the location of suitable recharge sites with agricultural land as land cover.

\subsubsection{Suitable recharge sites}

The main objective of this study was to delineate all those areas which are suitable for artificial recharge of groundwater. It was found that areas with slope of less than $5 \%$, having forest landcover and a NDVI value greater than 0.5 are the areas where groundwater level increased the most during one rainfall season. In another instance it was seen that groundwater level also increased in the areas with slope less than 5\%, 
having agricultural land. But the change in groundwater level was lower compared to forest land cover class. It was also observed that groundwater level is affected by the presence of joints, lineations and cleavages. So, from these observations it can be concluded that the areas with slope less than 5\%, having forest land cover and high NDVI $(>0.5)$ is suitable for artificial recharge. It has to be noted that the area to be considered for artificial recharge should also have high joint, cleavage, and lineation density. From this study the parameters have been ranked according to their relative contribution towards groundwater occurrence and recharge (Table 5-9).

Table 5-9. Ranking of parameters.

\begin{tabular}{|l|l|l|l|}
\hline $\begin{array}{l}\text { Sl. } \\
\text { No. }\end{array}$ & Criteria & Classes & Weight \\
\hline 1. & Geology & Mica schists and phyllites & 1 \\
\hline & & Quartzite & 2 \\
\hline 2. & Land cover & Forest & 1 \\
\hline & & Agriculture & 2 \\
\hline & & Water1 & 3 \\
\hline & & Water2 & 3 \\
\hline & & Unclassified & 4 \\
\hline 3. & NDVI & $>0.5$ & 1 \\
\hline & & $<0.5$ & 2 \\
\hline 4. & Slope & $<5 \%$ & 1 \\
\hline & & $>5 \%$ & 2 \\
\hline
\end{tabular}

\subsection{Discussion}

A study was carried out in a small catchment in the Wakal River basin to simulate the groundwater levels for different part of the year as a function of monsoon recharge and abstraction. This was done by developing a suitable conceptual model and then transforming into a steady- and transient-state numerical groundwater model using MODFLOW in PMWIN environment. The steady-state was successfully calibrated to 
obtain a mean error of 0.11 and NOF and NRMSE of 0.01 and 0.1 respectively between the simulated and observed heads. Recharge and transmissivity values were calibrated in the steady-state model to reach a good match between the simulated and observed heads. Different zones were created in the model domain to apply different recharge and transmissivity values. The application of recharge values throughout the model domain in a confined aquifer can be justified by the fact that the aquifer can act as a leaky confined aquifer and, therefore, receive recharge from the entire domain. Also, the saturated thickness does not change unlike in an unconfined aquifer. Hence, transmissivity should have been uniform if the hydraulic conductivity was uniform. The use of variable transmissivity can be justified by the fact that the thickness of the aquifer might not be uniform as assumed in the model and/or the hydraulic conductivity varies with position. The aquifer was assumed to be of uniform thickness and the transmissivities were identified by pumping tests which are in good agreement with literature values and subjected to only minor adjustments during calibration; hence, recharge was the major unknown parameter. Under the circumstance of well known transmissivity, calibration of the steady-state confined aquifer groundwater model is a powerful tool for recharge estimation. Proper amounts of recharge must be applied to the model to reproduce the field-measured values of heads and achieve calibration.

The calibrated steady-state model was used to set up a transient model which was also calibrated with a fairly good match between the simulated and observed heads in some wells. Three model scenarios were then developed to see the effect of decreased recharge and increased pumping. It has been seen that the groundwater levels will not show extreme decline in majority of the catchment area if the groundwater withdrawal is 
increased by $15 \%$. The eastern part of the catchment, however, might see a significant decline in groundwater levels of up to $4 \mathrm{~m}$. Again, if the area faces 2 years of drought to cause a reduction in recharge in every four years, the groundwater water levels in the entire domain will decline by $3 \mathrm{~m}$ in some areas. In both cases, it has been seen that the groundwater levels will decline but not significantly to pose widespread problems, though individual wells could go dry. This can be well explained by the fact that the aquifer may be sufficiently recharged even if there is decline in rainfall. It has been shown in the model that recharge of only $2 \%$ of precipitation takes place in the area, which is a major finding of this modeling work. Therefore, even if rainfall was reduced by $24 \%$ in model scenario 2 , significant decline in groundwater was not observed. In the third scenario, however, when the recharge was decreased as a result of drought in two years occurring in every four years, and the groundwater withdrawal is increased by $15 \%$, the groundwater levels could be greatly impacted throughout the catchment and in some wells by as much as $9 \mathrm{~m}$.

The conjunctive use of GIS and remote sensing to delineate the potential recharge zones demonstrated that the suitable areas should have a forest or agricultural land cover, slope less than $5 \%$ and NDVI greater than 0.5 . Furthermore, rock types, and structures such as cleavages and joints are very important factors affecting recharge zones. 


\subsection{CONCLUSIONS AND RECOMMENDATIONS}

Conclusions and recommendations are based on the research questions which were formulated to achieve specific objectives of the study.

This study shows that groundwater is the major source of water in the study area. Because of the absence of surface water resources, people depend heavily on groundwater. The major uses of groundwater include water for drinking purposes for people and domestic animals, domestic use, and irrigation. It has to be mentioned that more than $90 \%$ of groundwater is used for irrigation purposes. Groundwater exists under water table conditions. The flow of groundwater is immensely affected by the geology of the area. Mica-schists, phyllites, and quartzites are the main rock types dominating the area. Since these rocks are hard and compact, groundwater exists only in weathered and fractured horizons. Geological structures play a major role in the movement of groundwater. The cleavages of the rocks are mostly oriented in the north-south direction while the joints are oriented in the east-west direction. The groundwater velocity vector map (Figure 5.13) indicates that groundwater moves north in the southern part of the area and in the eastern and northern part, groundwater moves west.

The transmissivity of the aquifer was determined to be $38 \mathrm{~m}^{2} / \mathrm{d}$ based on pumping tests. These pumping test results are not representative enough to determine the spatial variability of aquifer properties. However, the optimized values obtained during steadystate model calibration varied between $27-50 \mathrm{~m}^{2} / \mathrm{d}$ close to measured. The aquifer thickness was conceptualized as a system with constant thickness of $20 \mathrm{~m}$.

Recharge in the study area was initially assumed to be $10 \%$ of annual rainfall. However, model-calculated recharge value was about $2 \%$ of annual rainfall and also 
shows a high spatial variation. Under the circumstance of well known transmissivity, calibration of the steady-state confined aquifer groundwater model is a powerful tool for recharge estimation. Proper amounts of recharge must be applied to the model to reproduce the field-measured values of heads and achieve calibration.

Monitoring wells should be constructed for proper monitoring of groundwater levels and they should be uniformly distributed over the entire area. Lithologic details from borings and well excavations would be beneficial for improving the conceptual model and hence the numerical model. Long-term and systematic collection of groundwater level data in monitoring wells spread throughout the catchment will be beneficial to better understand the behavior of the aquifer and to develop improved transient-state models.

Additional data on river discharge, runoff, distribution of ET, and estimation of base flow will help in significantly enhancing understanding of basin hydrology.

Both steady- and transient-state models were calibrated successfully to replicate the field measured values within acceptable error. Three different modeling scenarios were presented. The third scenario with two successive drought years in every four years and increased withdrawal by $15 \%$ showed that the ground water level decreased by as much as $9 \mathrm{~m}$ in some wells. The effect of such drought is currently uncertain however, because the runoff from the basin is unknown. Much of the precipitation falling on the basin may be rejected by the low storage capacity of the fractured rock aquifer. It has been noticed that people, especially men, migrate to different states in the summer season to search for jobs. Also, women have to walk for miles to get drinking water for their family. The main cause behind this is the scarcity of water. Potential solutions would 
involve formulation of laws to prevent indiscriminate use of groundwater as well as initiatives to implement Integrated Water Resource Management. Improper use of water will only make situations worse especially during drought periods. Results from the groundwater model can aid in the decision making process.

This groundwater modeling study in this area is one of the first detailed studies about groundwater and hydrogeology of the area. It was attempted to model the area as realistically as possible. This model can be significantly refined and improved by addition of new and reliable data. Furthermore, the recharge sites delineated by using GIS and remote sensing could be highly beneficial for the people in this area and may be used for the construction of artificial recharge structures. However, it is recommended that accuracy assessment of land cover map generated from satellite imagery be performed and thorough geological investigation of the area should be carried out to make results more convincing. Krigged surfaces of groundwater levels should be cross-validated for more accuracy.

Finally, it can be concluded that this groundwater modeling study successfully explained the overall behavior of the aquifer and its parameters as well as processes associated with it, such as recharge. This study was also successful in developing a reasonable conceptual model which can be converted into a numerical model with a capability to reproduce field measured data with comparatively good accuracy. This model should be refined with more detail for better accuracy. This study also demonstrated the capabilities of remote sensing and GIS for evaluation of groundwater resources and demarcation of groundwater prospect zones. 


\section{REFERENCES}

Abdulla, F.A., Al-Khatib, M.A., and Al-Ghazzawi, Z.D. 2000. Development of groundwater modeling for the Azraq Basin, Jordan. Environmental Geology. v40 (1-2). 18p.

AFPRO. 2007. Socio-economic condition assessment report: Wakal River Basin, India. 2008. Global Water for Sustainability Program, Florida International University. $57 \mathrm{p}$.

Ala Eldin, M.E.H., Ahmad M.S., Gurunadha Rao, V.V.S., and Dhar, R.L. 2000. Aquifer modeling of the Ganga-Mahawa sub-basin, a part of Central Ganga plain, Uttar Pradesh, India. Hydrological Processes. v14. pp. 297-315

Allen, R.G., Pereira, L.S., Raes, D., and Smith, M. 1998. Crop evapotranspiration Guidelines for computing crop water requirements - FAO Irrigation and Drainage Paper 56.

Anbazhagan, S., Ramasamy, S. M., and Das Gupta, S. 2005. Remote sensing and GIS for artificial recharge study, runoff estimation and planning in Ayyar basin, Tamil Nadu, India. Environmental Geology. v48 (2). pp. 158-170.

Anderson, M.P. and Woessner, W.W. 2002. Applied groundwater modeling simulation of flow and advective transport. Academic Press. San Diego, California. 381p.

Bouwer, H. 1978. Groundwater hydrology. McGraw-Hill, Inc. U.S. 480p.

CGWB. 1986. Manual on analysis of pumping test data of large diameter wells. Technical Series-M, No. 2. Central Ground Water Board (CGWB). Ministry of Water Resources. Faridabad, India. 33p.

Chand, R., Chandra, S., Rao, V.A., Singh, V.S. and Jain, S.C. Estimation of natural recharge and its dependency on sub-surface geoelectric parameters. Journal of Hydrology. v299. pp. 67-83.

Chauhan, N.K., Sharma, B.L., and Mohemmad, S.A. 1996. Structural geometry and strain history of the early proterozoic Aravalli rocks of Gorimari, Udaipur district, Rajasthan. Journal Geological Society of India. v.47, pp 59-74.

Chauhan, N. K. 2007. Hydrogeology assessment report: Wakal River Basin, India. 2007. Global Water for Sustainability Program, Florida International University. 132p. 
Chiang, W.H., and Kinzelbach, W. 2003. 3D-groundwater modeling with PMWIN: A simulation system for modeling groundwater flow and pollution. Springer-Verlag. Berlin Heidelberg New York. 346p.

Davis, S.N., and DeWeist, R.J.M. 1996. Hydrogeology. John Wiley \& Sons, Inc., New York, NY. 463p.

de Vries, J.J, and Simmers, I. 2002. Groundwater recharge: an overview of processes and challenges. Hydrogeology Journal. v10 (5). 17p.

DOA. 1999. Groundwater hydrology. U.S. Army Corps of Engineers, Department of Army. Washington, D.C.

ECIDWR. 2005. Expert Committee on Integrated Development of Water Resources Report, 2005. Expert Committee on Integrated Development of Water Resources (ECIDWR), Jaipur, Rajasthan, pp. 1-43.

ESRI. 2006. ArcGIS 9: What is ArcGIS 9.2? Environmental Systems Research Institute (ESRI): Redlands, $126 \mathrm{p}$.

Freeze, R.A., and Cherry, J.A. 1979. Groundwater. Prentice Hall, Inc. Englewood Cliffs, N.J. 604p.

Gallardo, A.H., Reyes-Borja, W., and Tase, N. 2005. Flow and patterns of nitrate pollution in groundwater: a case study of an agricultural area in Tsukuba City, Japan. Environ Geol. v48. pp. 908-919.

Gieske, A.S.M., and Miranzadeh, M. 2002. Groundwater resources modeling of the Lenjanat aquifer system. Karaj, Esfahan, Colombo, Iranian Agricultural Engineering Research Institute (IAERI), Esfahan Agricultural Research Center (EARC), International Water Management Institute (IWMI). IAERI-IWMI Research Reports 15, 27 p.

GOR. 1979. Evaluation of hydraulic parameters of Aravalli phyllites and Erinpura granites. Government of Rajasthan. Jodhpur. India.

GOR, 2003. Ground Water Atlas of Rajasthan (2003), SRSAC, DST, Govt. of Rajasthan, Jodhpur.

GWP, 2000. Integrated Water Resources Management, TAC Background Papers No. 4, Global Water Partnership, Stockholm, Sweden. pp. 9 
Harbaugh, A.W., and McDonald, M.G. 1996. User's documentation for MODFLOW-96, an update to the U.S. Geological Survey modular finite-difference ground-water flow model: U.S. Geological Survey Open-File Report 96-485. 56 p.

ICID 2005. Water resources assessment of Sabarmati Basin, India. International Commission on Irrigation and Drainage (ICID), New Delhi, India. 65p.

Idrysy, H.E., and De Smedt, F. 2006. Modeling groundwater flow of the Trifa aquifer, Morocco. Hydrogeology Journal. 14. pp. 1265-1276

Jaiswal, R. K., Mukherjee, S., Krishnamurthy, and J., Saxena, R. (2003). Role of remote sensing and GIS techniques for generation of groundwater prospect zones towards rural development - an approach. International Journal of Remote Sensing. 24(5). pp. 993-1008.

Jensen, J.R. (2005). Introductory digital image processing -A remote sensing perspective. 3rd edn. Prentice Hall. Upper Saddle River, NJ. pp 310-311.

Krishnamurthy, J., Mani, A., Jayaraman, V., and Manivel, M. 2000. Groundwater resources development in hard rock terrain - an approach using remote sensing and GIS techniques. International Journal of Applied Earth Observation and Geoinformation 2(3/4). pp. 204-215

Kumar, M.D., Chopde, S., Mudrakartha, S, and Prakash, A. 1999. Chapter 5: Addressing Water Scarcity: Local Strategies for Water Supply and Conservation Management in the Sabarmati Basin, Gujarat, pp. 191-246. In Moench, M., Caspari, E., and Dixit, A. [eds], Rethinking the Mosaic: Investigations into Local Water Management. Nepal Water Conservation Foundation, Kathmandu, Nepal.

Kumar, S., Kumar, D., and Ahmed, S. 2006. Delineation of groundwater prospect zones in hard rocks using remote sensing and GIS - A case study from Rajasthan. Journal Geological Society of India. 68. pp. 259-268.

Mace, R., Chowdhury, A., Anaya, R., and Way, S. 2000. A numerical groundwater flow model of the Upper and Middle Trinity Aquifer, Hill Country Area. Open file report 00-02. Texas Water Development Board.

Mahnot, S.C. and Sharma, D.C.. 2003. Chapter 1: Water as a resource. pp. 5-14. In Kaul, V. [ed], Water Harvesting and Management. SDC/ICU, Jaipur, Rajasthan, India.

Mahnot, S.C. and Singh, P.K. 2003. Chapter 3: Agro-climatic conditions and surface water harvesting, pp. 26-34. In Kaul, V. [ed], Water Harvesting and Management. SDC/ICU, Jaipur, Rajasthan, India. 
Maidment, D.R., Ed. 2002. ArcHydro: GIS for Water Resources. Environmental Systems Research Institute (ESRI): Redlands, 203 p.

McDonald, M.G., and Harbaugh, A.W. 1988. A modular three-dimensional finitedifference ground-water flow model: Techniques of Water-Resources Investigations. U.S. Geological Survey. Book 6. Chapter A1.

McWhorter, D. and Sunada, D.K. 1977. Groundwater hydrology and hydraulics, Water Resources Publications, Littelton, Colorado.

Mohemmad, S.A. 1993. Structure and stratigraphy of the area around Gorimari, District Udaipur Rajasthan. Ph.D. Dissertation. Mohan Lal Sukhadia University. Udaipur. Rajasthan. India.

Narain, P., Khan, M.A., and Singh, G. 2005. Potential for water conservation and harvesting against drought in Rajasthan, India. Working Paper 104 (Drought Series: Paper 7). Colombo, Sri Lanka: International Water Management Institute (IWMI). pp. 1-25

Palma, H.C., and Bentley, L.R. 2007. A regional-scale groundwater flow model for the Leon-Chinandega aquifer, Nicaragua. Hydrogeology Journal. 15. pp. 1457-1472.

Paralta, E., and Oliviera, M. 2005. Assessing and modeling hard rock aquifer recharge based on complementary methodologies - A case study in the "Gabbros of Beja" aquifer system (South Portugal). $2^{\text {nd }}$ Workshop of the Iberian regional working group on hardrock hydrogeology. Evora, Portugal. 15p.

Pisinaras, V., Petalas, C., Tsihrintzis, V.A., and Zagana, E. 2007. A groundwater flow model for water resources management in the Ismarida plain, North Greece. Environmental Modeling and Assessment. 12. pp. 75-89.

Prasad, B., Mathur, R.K., Gupta, S.N., Iqbaluddin, and Arora, Y.K. 1997.

Lithostratigraphy. Memoirs of the Geological Survey of India. v123. pp. 16-85

Rao, N. S. 2006. Groundwater potential index in a crystalline terrain using remote sensing data. Environmental Geology. 50(7). pp. 1067-1076.

Rathore, M.S. 2005a. State level analysis of drought policies and impacts in Rajasthan, India. Working Paper 93. (Drought Series: Paper 6). Colombo, Sri Lanka: International Water Management Institute. pp. 1-29

Rathore, M.S. 2005b. Groundwater exploration and augmentation efforts in Rajasthan. Institute of Development Studies. Jaipur. Rajasthan. India. pp. 1-33. 
Ravi Shankar, M.N., and Mohan, G. 2006. Assessment of the groundwater potential and quality in Bhatsa and Kalu river basins of Thane district, western Deccan Volcanic Province of India. Environmental Geology. 49. pp. 990-998.

Rejani, R., Jha, M.K., Panda, S.N., and Mull, R. 2008 Simulation modeling for efficient groundwater management in Balasore coastal basin, India. Water Resources Management. v22. pp. 23-50.

Rivera, M.P. 2002. A numerical groundwater model for Urania (Sao Paulo, Brazil). M.S. Thesis. Lulea University of Technology, Sweden.

Roy, A. B. 1988. Stratigraphic and tectonic framework of the Aravalli mountain range. In: A B Roy (ed) Precambrian of the Aravalli mountain, Rajasthan, India. Memoirs of the Geological Survey of India. v7. pp. 3-31.

Saraf, A.K., Choudhury, P.R. 1998. Integrated remote sensing and GIS for groundwater exploration and identification of artificial recharge sites. International Journal of Remote Sensing. v19 (10). pp. 1825-1841.

Saraf, A.K., Choudhury, P.R., Roy, B., Sarma, B., Vijay, S., and Choudhury, S. 2004. GIS based surface hydrological modeling in identification of groundwater recharge zones. International Journal of Remote Sensing. v25 (24), pp. 57595770 .

Senthil Kumar, M., and Elango, L. 2004. Three-dimensional mathematical model to simulate groundwater flow in the lower Palar River basin, Southern India. Hydrogeology Journal. v12. pp. 197-208.

Schwartz, F.W. and Zhang, H. 2003. Fundamentals of groundwater. John Wiley, Hoboken,N.J. 583p.

Srinivas, A., Venkateswara Rao, B., and Gurunadha Rao, V.V.S. 1999. Recharge process and aquifer models of a small watershed. Hydrological Sciences-Journal-des Sciences Hydrologiques. v44 (5). pp. 681-1052.

Srivastava, P. K., and Bhattacharya, A. K. 2006. Groundwater assessment through an integrated approach using remote sensing, GIS and resistivity techniques: a case study from a hard rock terrain. International Journal of Remote Sensing v27 (20). pp. $4599-4620$

Sukhija, B.S., Nagabhushanam, P., and Reddy, D.V. 1996. Groundwater recharge in semi-arid regions of India: An overview of results obtained using tracers. Hydrogeology Journal. v4. (3). pp.50-71 
UNDP. 2005. Looking to the future. Groundwater management in Rajasthan: Issues, Perspectives \& Policy. A National Consultation Organised by Jal Bhagirathi Foundation and UNDP. Jaipur. Rajasthan. 16p.

Wang, H.F., and Anderson, M.P. 1982. Introduction to groundwater modeling: finite difference and finite element methods. W.H. Freeman, 256p.

Wen, X.H., Wu, Y.Q., Lee, L.J.E., Su, J.P., and Wu, J. 2007. Groundwater flow modeling in the Zhangye Basin, Northwestern China. Environmental Geology. 53. pp. 77 84.

Wiszniewski, I., Lertsirivorakul, R., Merrick, N.P., Milne-Home, W.A., and Last, R.A. 2005. Groundwater flow section modelling of salinisation processes in the Champhone Catchment, Savannakhet Province, Lao PDR. International Conference on Simulationand Modeling 2005, Nakornpathom, Thailand, January 2005 in SimMod Simulation and Modelling, ed Kachitvichyanukul, V; Purintrapiban, U; Utayopas, P, On web, Thailand, pp. 1-9.

Yihdego, Y. 2005. A three dimensional groundwater model of the aquifers around Lake Navaisha area, Kenya. M.S. Thesis. International Institute for Geo-Information Science and Earth Observation, Enschede, The Netherlands.

\section{UNPUBLISHED DATA}

Singh, P.K. unpublished data, 2006. Climatology Data of Udaipur. Department of Soil and Water Conservation Engineering: Maharana Pratap University of Agricultural and Technology (MPUAT), Udaipur, India. 


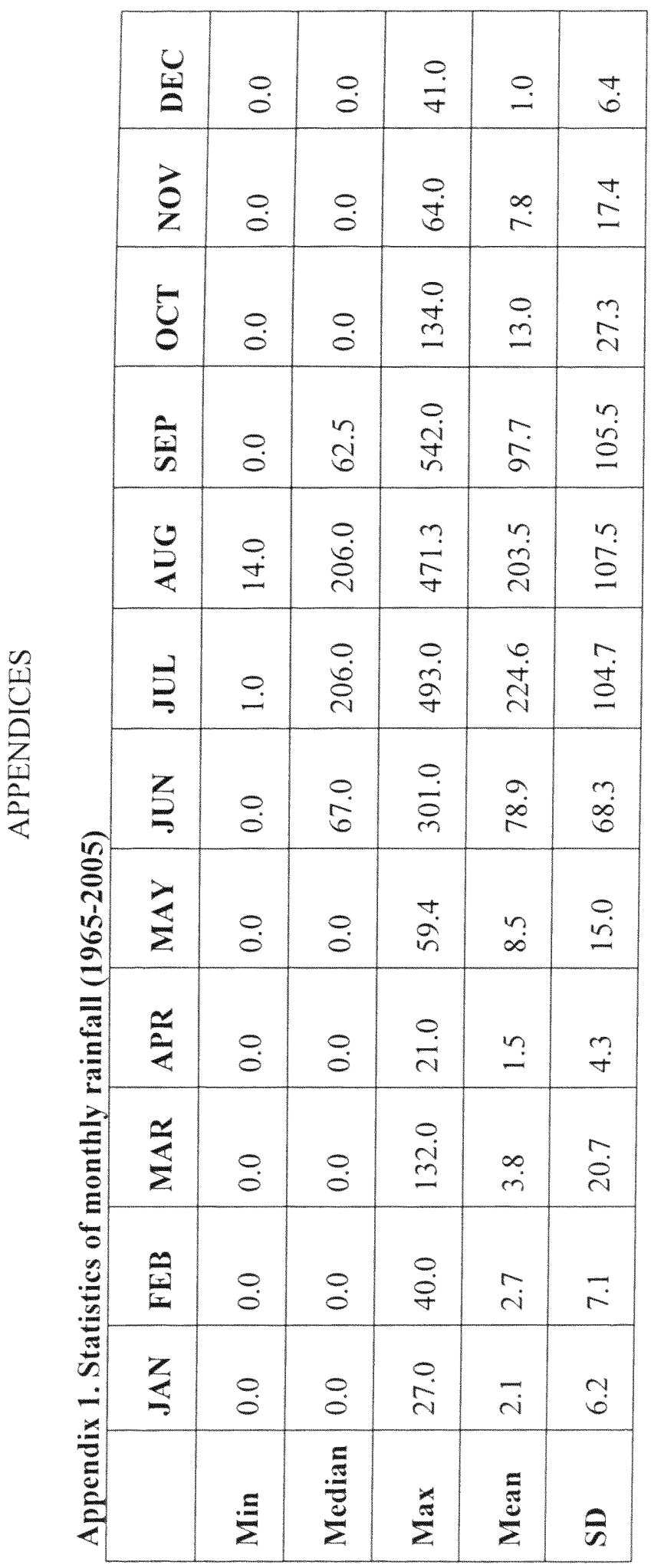




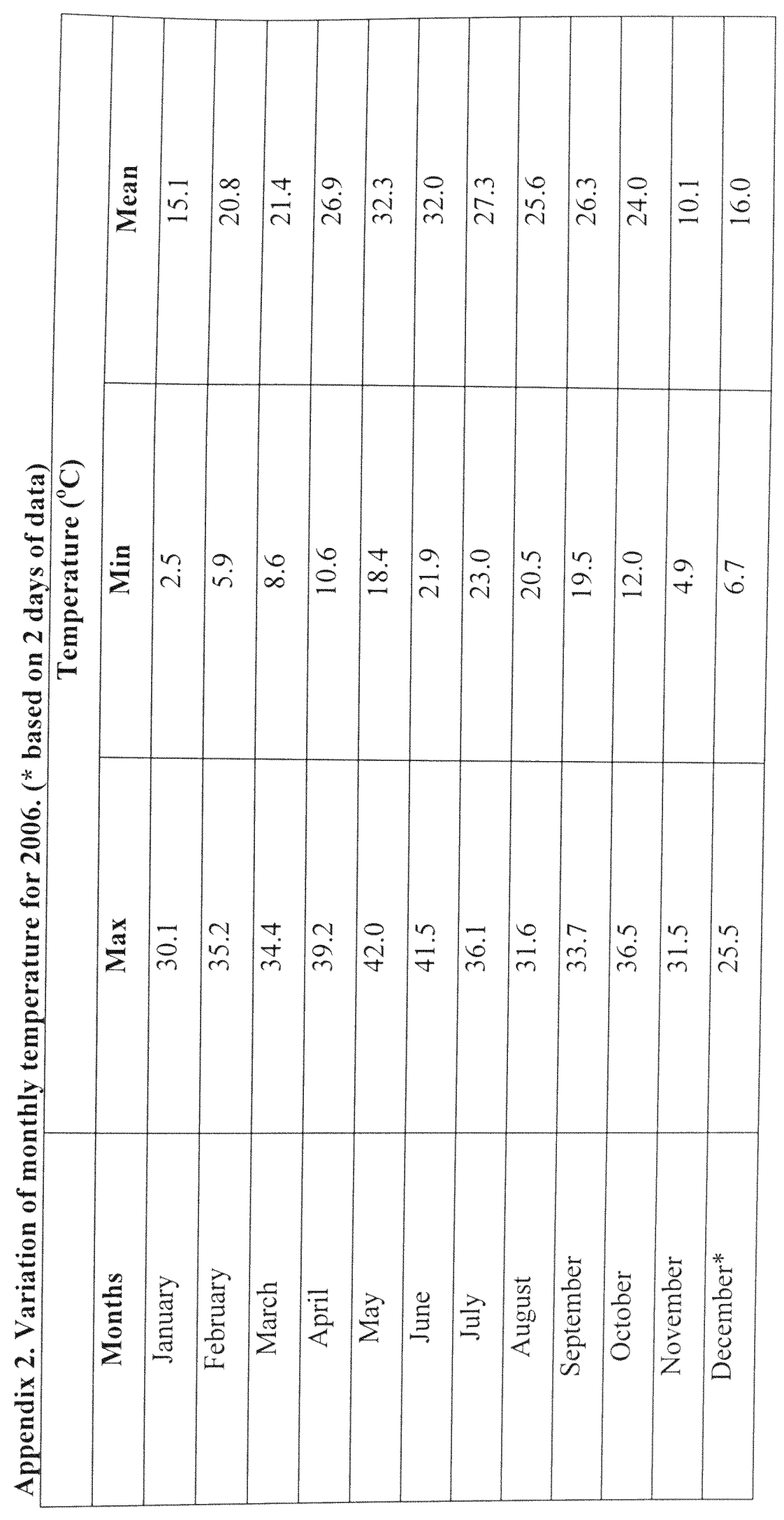




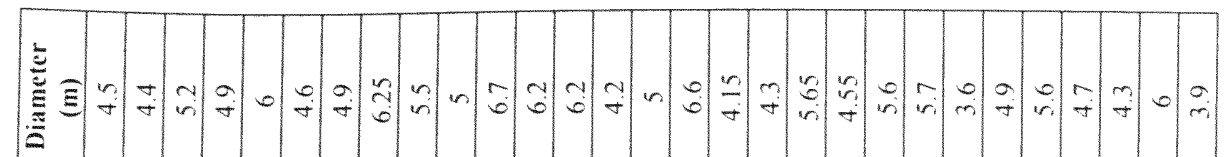

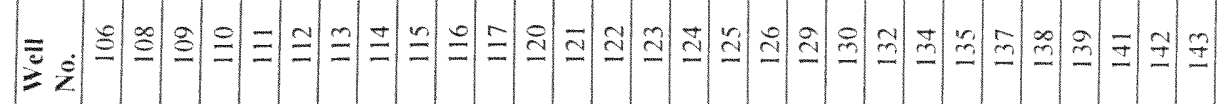

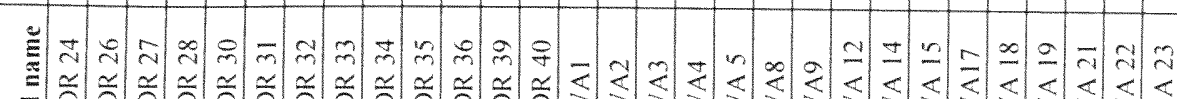

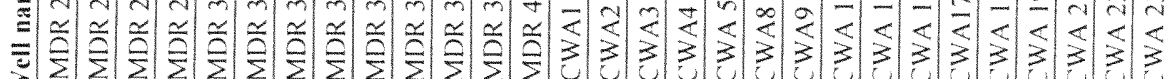

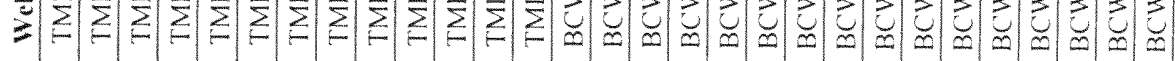

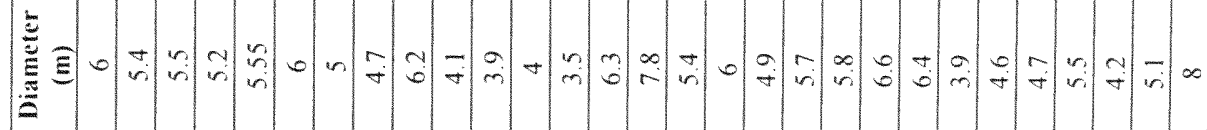

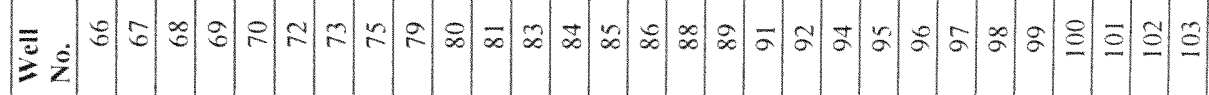

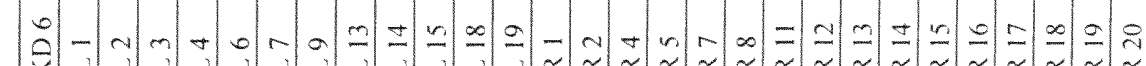

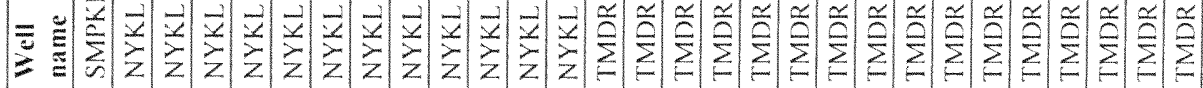

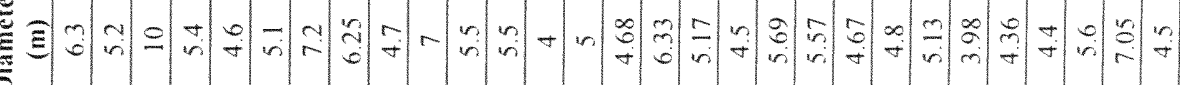

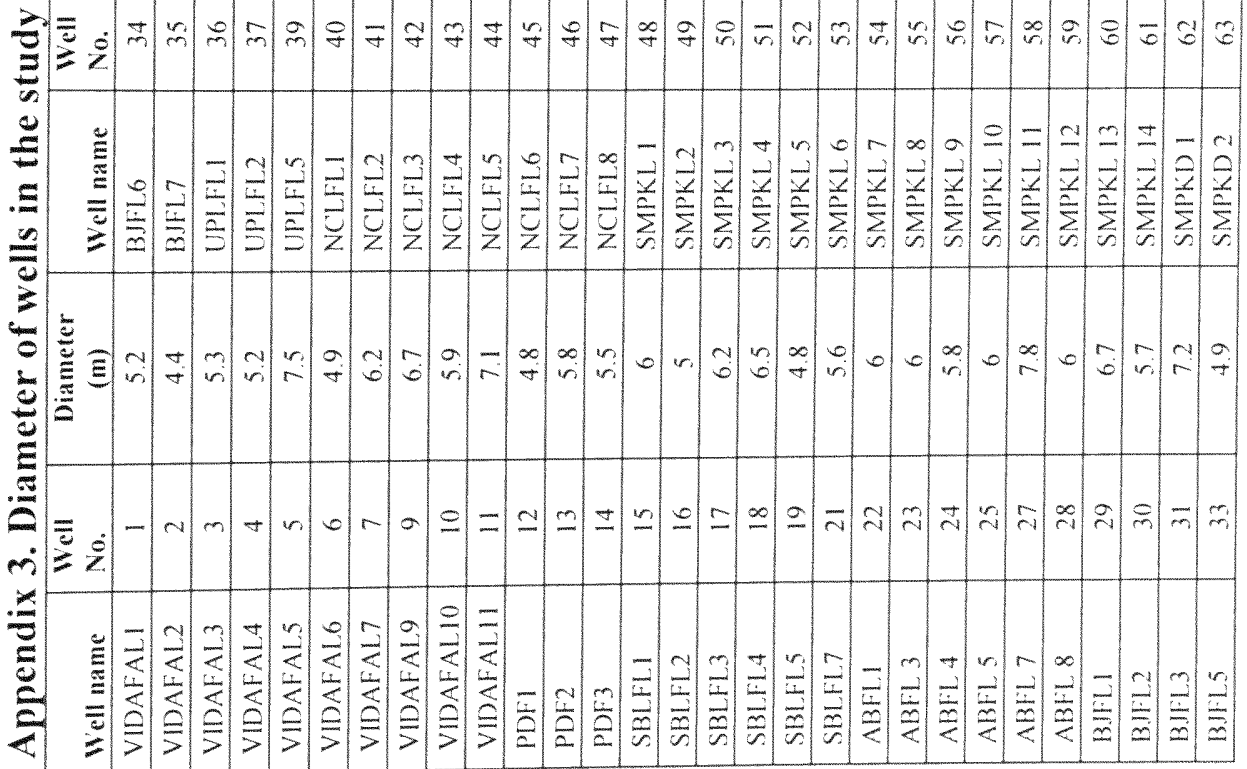




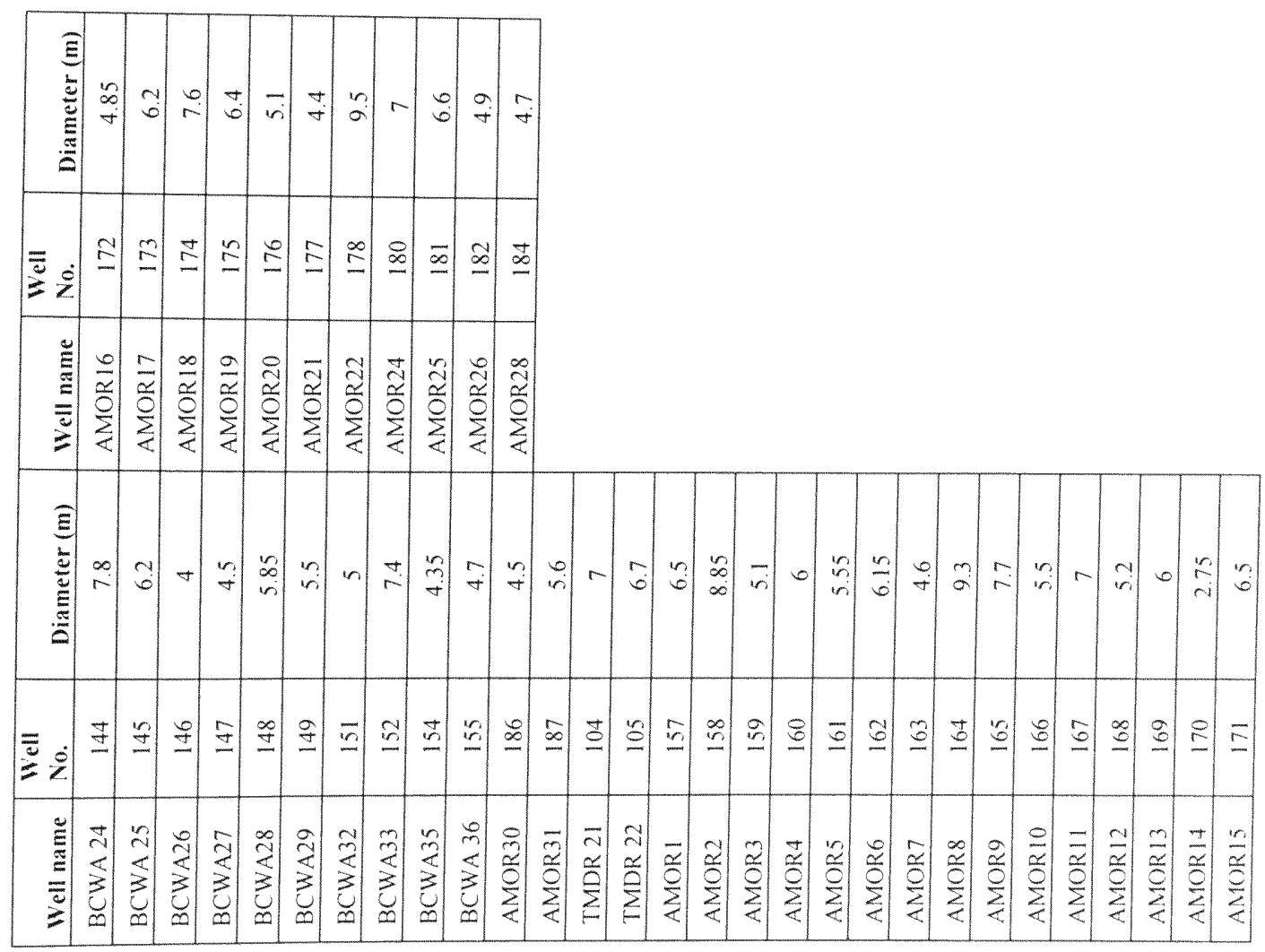




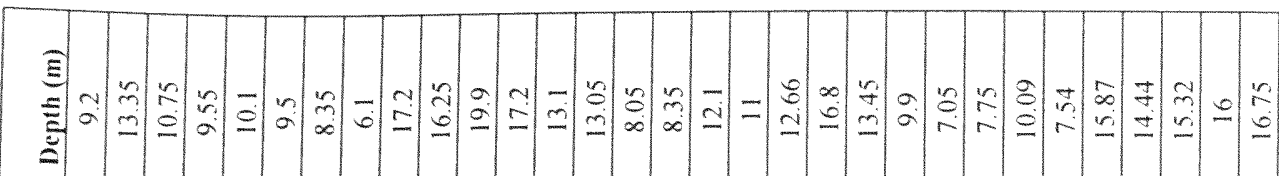

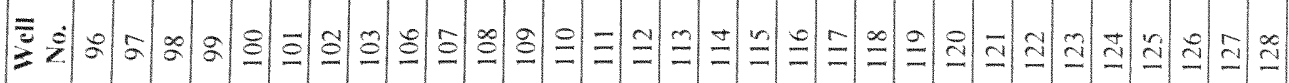

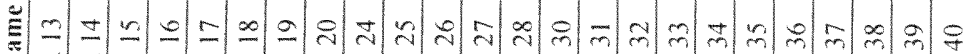

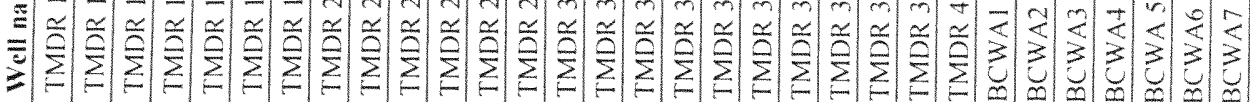

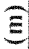

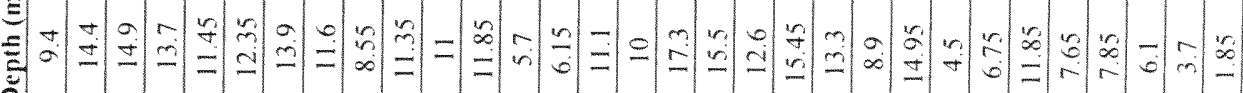

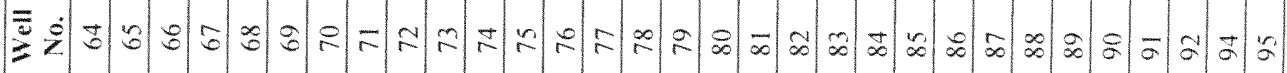

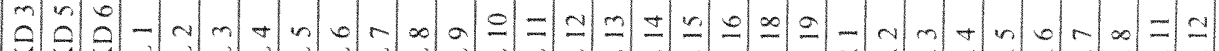

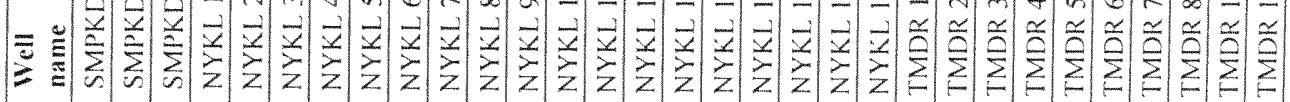

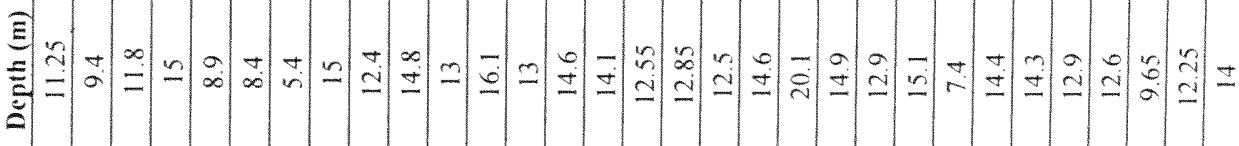

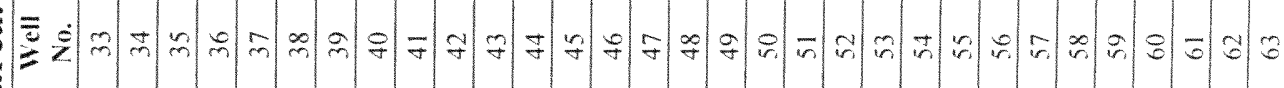

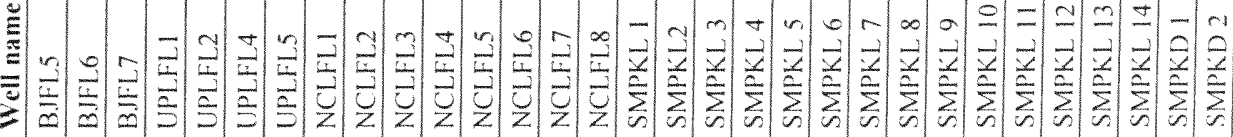

$=$

$=$
$\overline{0}$
$\vdots$
$\vdots$
$\vdots$
0
0

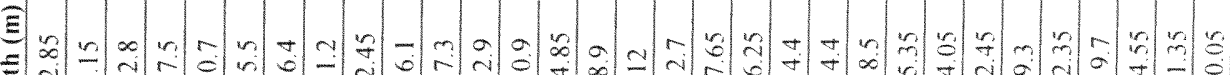

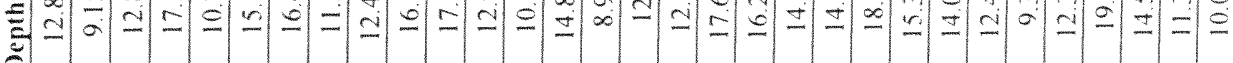

5

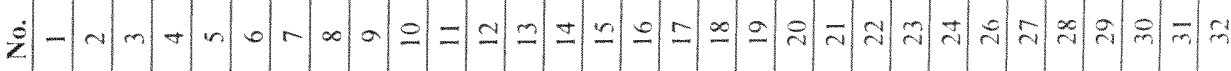

$\stackrel{\square}{\Xi}$

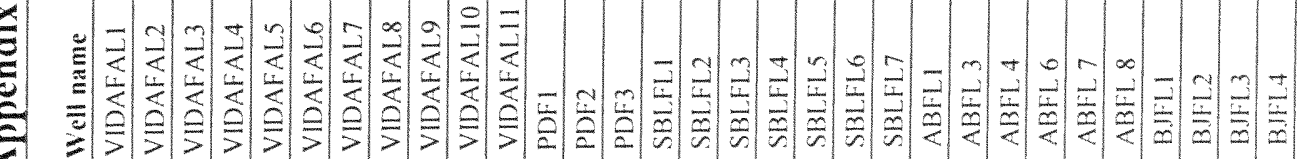




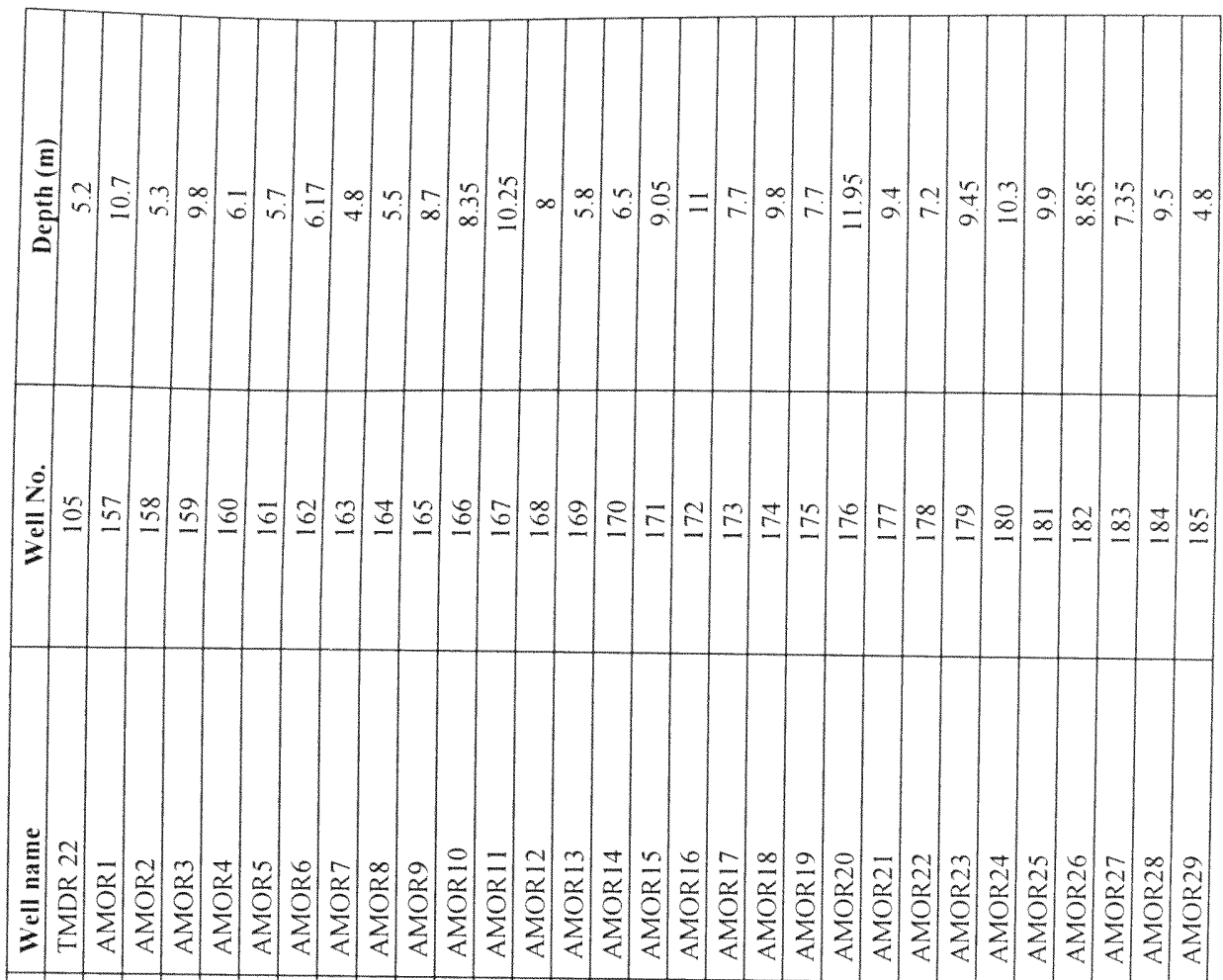

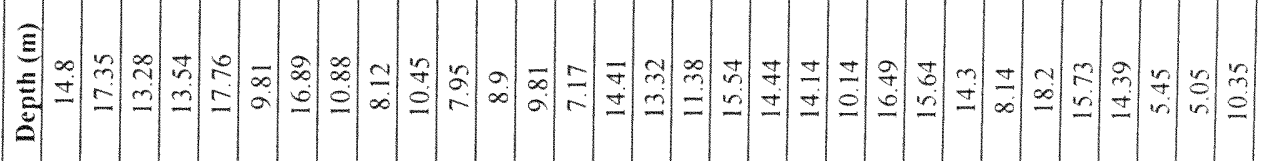

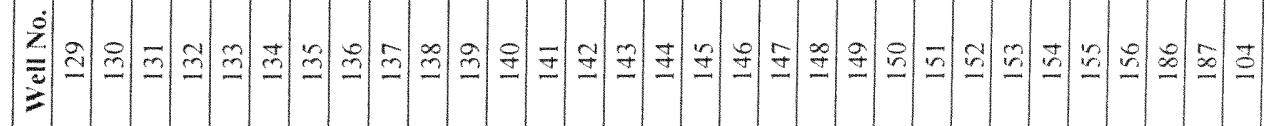

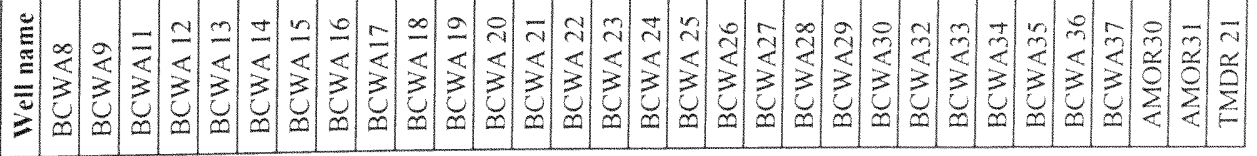


Appendix 5. Time drawdown data of Shyampurakala aquifer test.

\begin{tabular}{|c|c|c|c|}
\hline $\begin{array}{c}\text { Time } \\
(\mathbf{m})\end{array}$ & $\begin{array}{c}\text { drawdown } \\
(\mathbf{m})\end{array}$ & $\begin{array}{c}\text { Time } \\
(\mathrm{m})\end{array}$ & $\begin{array}{c}\text { drawdown } \\
(\mathbf{m})\end{array}$ \\
\hline 1 & 0.03 & 28 & 0.55 \\
\hline 2 & 0.05 & 29 & 0.57 \\
\hline 3 & 0.065 & 30 & 0.585 \\
\hline 4 & 0.09 & 31 & 0.605 \\
\hline 5 & 0.106 & 32 & 0.623 \\
\hline 6 & 0.125 & 33 & 0.64 \\
\hline 7 & 0.15 & 38 & 0.735 \\
\hline 8 & 0.169 & 43 & 0.82 \\
\hline 9 & 0.188 & 48 & 0.905 \\
\hline 10 & 0.205 & 53 & 0.995 \\
\hline 11 & 0.225 & 58 & 1.075 \\
\hline 12 & 0.245 & 63 & 1.16 \\
\hline 13 & 0.265 & 68 & 1.24 \\
\hline 14 & 0.28 & 73 & 1.32 \\
\hline 15 & 0.304 & 83 & 1.47 \\
\hline 16 & 0.325 & 93 & 1.62 \\
\hline 17 & 0.341 & 103 & 1.762 \\
\hline 18 & 0.362 & 113 & 1.9 \\
\hline 19 & 0.381 & 123 & 2.03 \\
\hline 20 & 0.405 & 133 & 2.16 \\
\hline 21 & 0.419 & 143 & 2.279 \\
\hline 22 & 0.439 & 153 & 2.39 \\
\hline 23 & 0.46 & 163 & 2.495 \\
\hline 24 & 0.48 & 173 & 2.56 \\
\hline 25 & 0.495 & 188 & 2.64 \\
\hline 26 & 0.513 & 203 & 2.746 \\
\hline 27 & 0.532 & 218 & 2.895 \\
\hline & & & \\
\hline
\end{tabular}


Time-drawdown data of Amor aquifer test

\begin{tabular}{|c|c|c|c|}
\hline $\begin{array}{l}\text { Time } \\
(\min )\end{array}$ & drawdown $(\mathrm{m})$ & $\begin{array}{l}\text { Time } \\
(\mathrm{min})\end{array}$ & drawdown (m) \\
\hline 1 & 0.06 & 44 & 1.69 \\
\hline 2 & 0.08 & 47 & 1.8 \\
\hline 3 & 0.12 & 50 & 1.93 \\
\hline 4 & 0.16 & 53 & 2.06 \\
\hline 5 & 0.19 & 56 & 2.18 \\
\hline 6 & 0.22 & 59 & 2.29 \\
\hline 7 & 0.26 & 62 & 2.41 \\
\hline 8 & 0.3 & 65 & 2.54 \\
\hline 9 & 0.34 & 68 & 2.66 \\
\hline 10 & 0.38 & 71 & 2.79 \\
\hline 11 & 0.41 & 74 & 2.9 \\
\hline 12 & 0.45 & 77 & 3.03 \\
\hline 13 & 0.48 & 80 & 3.14 \\
\hline 14 & 0.52 & 85 & 3.35 \\
\hline 15 & 0.56 & 90 & 3.55 \\
\hline 16 & 0.6 & 95 & 3.74 \\
\hline 17 & 0.63 & 100 & 3.93 \\
\hline 18 & 0.67 & 105 & 4.12 \\
\hline 19 & 0.71 & 110 & 4.33 \\
\hline 20 & 0.75 & 115 & 4.52 \\
\hline 23 & 0.85 & 120 & 4.7 \\
\hline 26 & 0.97 & 130 & 5.02 \\
\hline 29 & 1.08 & 140 & 5.45 \\
\hline 32 & 1.21 & 150 & 5.62 \\
\hline 35 & 1.31 & 160 & 5.87 \\
\hline 38 & 1.45 & 170 & 6.12 \\
\hline 41 & 1.58 & 180 & 6.32 \\
\hline
\end{tabular}

